\title{
Patrícia Martin
}

\section{Estudo da interação endotélio-matriz extracelular no remodelamento da pele observado no modelo experimental de esclerodermia e na enfermidade espontânea humana}

Tese apresentada à Faculdade de Medicina da Universidade de São Paulo para obtenção do título de Doutor em Ciências

Programa de Ciências Médicas

Área de Concentração: Processos Imunes e Infecciosos Orientador: Prof. Dr. Natalino Hajime Yoshinari

\section{São Paulo 2012}


Dados Internacionais de Catalogação na Publicação (CIP)

Preparada pela Biblioteca da

Faculdade de Medicina da Universidade de São Paulo

Creprodução autorizada pelo autor

Martin, Patrícia

Estudo da interação endotélio matriz extracelular no remodelamento da pele observado no modelo experimental de esclerodermia e na enfermidade espontânea humana / Patrícia Martin. -- São Paulo, 2012.

Tese(doutorado)--Faculdade de Medicina da Universidade de São Paulo.

Programa de Ciências Médicas. Área de concentração: Processos Imunes e Infecciosos

Orientador: Natalino Hajime Yoshinari.

Descritores: 1.Colágeno tipo V 2.Esclerose sistêmica 3.Derme 4.Células endoteliais 5.Apoptose 6.Modelos animais

USP/FM/DBD-247/12 


\section{DEDICATÓRIA}

Aos meus queridos pais Edite e Evilásio, por todas as oportunidades, ensinamentos, dedicação e incentivo. A eles devo tudo que sou.

Ao meu querido esposo Marcelo, por repartir comigo todos os momentos, por estar sempre presente, me ajudando, me ouvindo, me incentivando.

Às minhas irmãs Sandra, Eloisa e Liciê, minhas verdadeiras amigas e conselheiras, ao meu cunhado Rodrigo, que se tornou também um irmão, e aos meus queridos sobrinhos, Gabriel e Letícia.

À Sueli e ao Zacarias, que me receberam como uma filha, agradeço pelo incentivo, carinho e compreensão. 


\section{AGRADECIMENTOS}

A Deus, pelo dom da vida, pelas oportunidades e pelas pessoas que colocou em meu caminho.

Ao meu querido orientador, Prof. Dr. Natalino Hajime Yoshinari, por ter aceitado o desafio de me orientar, por ter se revelado uma pessoa maravilhosa, por tudo que me ensinou e pela sua dedicação, paciência e sinceridade.

À Dra Walcy Rosolia Teodoro, verdadeira pesquisadora, por ter acreditado em meu potencial e por ter me recebido de braços abertos em seu laboratório. Agradeço não só pelos ensinamentos técnicos e científicos, mas pelo exemplo de dedicação e perseverança e, sobretudo, por ter ser tornado uma grande amiga.

À Dra Ana Paula Pereira Velosa, por ter transmitido seus conhecimentos com paciência e serenidade, por sua disposição de sempre me auxiliar prontamente na padronização e realização das metodologias utilizadas neste trabalho e, principalmente, pela sua humildade, lição que ensinou sem palavras, mas com seu exemplo, e que levarei comigo para o resto de minha vida.

À Solange Carrasco, por ter me ensinado a cultivar fibroblastos e por ter se tornado uma grande amiga.

À Prof. Dra Vera Luiza Capelozzi, por seus ensinamentos de patologia, por sua disponibilidade e por suas palavras de incentivo.

Ao Dr. Edwin Roger Parra, sempre presente, pela sua amizade e por seu auxílio na aquisição e interpretação dos dados deste trabalho. 
À Prof. Dra Eloisa Bonfá, pela oportunidade dentro da Disciplina de Reumatologia da FMUSP e no curso de pós-graduação e por ter me ensinado a como dizer as coisas.

À Jymenez de Morais, por seu auxílio na realização dos experimentos de biologia molecular; pela sua amizade e pela alegria que espalhava onde quer que estivesse.

À Dra Maria Lúcia Katayama, pela ajuda na interpretação dos dados provenientes dos experimentos de biologia molecular.

Às amigas do laboratório de matriz extracelular Adriana Marcelino, Isabele Brindo da Cruz e Natália Borsonello, pelo companheirismo e pela ajuda em vários procedimentos laboratoriais.

À Dra Romy Beatriz Christmann, por ter cedido parte da casuística utilizada neste trabalho e, principalmente, por ter se tornado um bom exemplo que tento seguir desde que a conheci, ainda nos tempos de faculdade.

À Sandra Fernezlian, pela padronização e realização das reações de imunohistoquímica, por sempre me atender prontamente e com muito carinho, mesmo em meio a grandes tempestades.

À Dra Ana Garipo, pela aquisição das imagens no microscópio confocal e pelo carinho com que sempre me recebia.

À Dra Mírian N Sotto, pela sua contribuição e por ceder alguns casos utilizados neste trabalho. 
Às funcionárias da patologia Weluma, Paula, Kelly e Cássia, pela gentileza com que sempre me atenderam.

À Carolina Colombo, aluna de iniciação científica, pelo auxílio na quantificação do CTGF.

À Francince Fontes Rico Braga, pela padronização da metodologia para extração do colágeno do sobranadante da cultura de fibroblastos.

Ao Banco de Pele do Departamento de Cirurgia Plástica da Faculdade de Medicina da Universidade de São Paulo, em especial ao Dr. Cesar Isaac e à Sivana Altran.

Ao Dr. Mário Guilherme Cesca Rocha, que me deu o peixe ao realizar algumas biópsias de pele e que me ensinou a pescar ao me instruir como fazer o procedimento e também pelo carinho e cuidado com que tratava os pacientes.

À Sandra Martin, pelo incentivo e pela ajuda fundamental na redação do paper e da tese.

À secretária do ambulatório Cristina Nazareth, pela ajuda e cumplicidade nos ambulatórios, e à enfermeira Neide, pela ajuda nas biópsias de pele.

Ao Dr. Ricardo Fuller e à Dra Maria Tereza Calleiro, pessoas que não contribuíram diretamente na elaboração desta tese, mas cuja presença me inspirou e serviu de estímulo para continuar.

Aos meus amigos Maurício e Rejane, que não se afastaram de mim neste período de reclusão, e à Dra Liz Valim, que em pouco tempo se tornou uma amiga e que também contribuiu indiretamente para a conclusão desta tese. 
Agradeço de maneira especial aos pacientes que concordaram em participar deste estudo, doando um pouco de si em benefício da ciência e de seus semelhantes. 
Esta tese está de acordo com as seguintes normas, em vigor no momento desta publicação:

Referências: adaptado de International Committee of Medical Journals Editors (Vancouver)

Universidade de São Paulo. Faculdade de Medicina. Serviço de Biblioteca e Documentação. Guia de apresentação de dissertações, teses e monografias. Elaborado por Anneliese Carneiro da Cunha, Maria Julia de A. L. Freddi, Maria F. Crestana, Marinalva de Souza Aragão, Suely Campos Cardoso, Valéria Vilhena. $2^{\mathrm{a}}$ ed. São Paulo: Serviço de Biblioteca e Documentação; 2005.

Abreviaturas dos títulos dos periódicos de acordo com List of Journals Indexed in Index Medicus. 


\section{LISTA DE ABREVIATURAS E SIGLAS}

\begin{tabular}{|c|c|}
\hline CAPPesq & Comitê de Ética para Análise de Projetos de Pesquisa \\
\hline cDNA & DNA Complementar \\
\hline CMV & Citomegalovirus \\
\hline COLI & Colágeno tipo I \\
\hline COLIII & Colágeno tipo III \\
\hline COLV & Colágeno tipo V \\
\hline COLV-IM & Imunizado com Colágeno V \\
\hline CTGF & Fator de Crescimento do Tecido Conjuntivo \\
\hline DMEM & Meio de Dulbeco modificado por Eagle \\
\hline EBV & Vírus Epstein-Bar \\
\hline ELAM-1 & Molécula de Adesão Endotélio Leucócito-1 \\
\hline ES & Esclerose Sistêmica. \\
\hline ET1 & Endotelina-1 \\
\hline ETA & Receptor da Endotelina tipo A \\
\hline ETB & Receptor da Endotelina tipo B \\
\hline FMUSP & Faculdade de Medicina da Universidade de São Paulo \\
\hline$H \& E$ & Hematoxilina e Eosina \\
\hline ICAM-1 & Molécula de Adesão Intercelular-1 \\
\hline IL-4 & Interleucina-4 \\
\hline IL-17 & Interleucina-17 \\
\hline $\mathrm{MHC}$ & Complexo Maior de Histocompatibilidade \\
\hline
\end{tabular}




$\begin{array}{ll}\text { mRNA } & \text { RNA Mensageiro } \\ \text { MRSS } & \text { Escore de Rodnan Modificado } \\ \text { PBS } & \text { Tampão Fosfato Salino } \\ \text { PDGF } & \text { Fator de Crescimento Derivado de Plaquetas } \\ \text { RN } & \text { Ácido Ribonucleico } \\ \text { SBCAL/COBEA } & \text { Sociedade Brasileira de Ciências em Animais de } \\ & \text { Laboratório } \\ \text { TGF- } \beta & \text { Fator de Crescimento Transformador Beta } \\ \text { VCAM-1 } & \text { Molécula de Adesão Vascular-1 } \\ \text { VEGF } & \text { Fator de Crescimento Vascular Endotelial }\end{array}$




\section{LISTA DE FIGURAS}

Figura 1 - Estrutura de uma molécula típica de colágeno

Figura 2 - Pontes intra e intermoleculares dos colágenos fibrilares

Figura 3 - Diagrama esquemático mostrando a biossíntese dos colágenos fibrilares.

Figura 4 - Desenho esquemático da interação dos colágenos I e V nas fibras heterotípicas.

Figura 5 - Diagnóstico histológico da ES e pele controle. 32

Figura 6 - Diagrama esquemático da área medida 37

Figura 7 - Identificação das células endoteliais em apoptose através da imunomarcação com caspase-3.

Figura 8 - Identificação dos fibroblastos na cultura celular 45

Figura 9 - Imunomarcação do COLV na derme de pacientes com ES e controles

Figura 10 - Imunomarcação do COLI na derme de pacientes com ES e controles

Figura 11 - Imunomarcação do COLIII na derme de pacientes com ES e controles

Figura 12 - Reconstrução tridimensional das fibras heterotípicas presentes na cultura de fibroblastos dérmicos 
Figura 13 - Eletroforese e immunoblot do COLV proveniente da cultura de fibroblastos dérmicos.

Figura 14 - Aspecto histológico da derme dos animais controle e COLV- IM

Figura 15 - Expressão de COLV na derme dos animais controle e COLV-IM

Figura 16 - Apoptose e ativação das células endoteliais no modelo animal induzido pela imunização com COLV

Figura 17 - Mecanismo proposto para patogênese da ES 102 


\section{LISTA DE QUADROS}

Quadro 1 - Protocolo de imunização dos coelhos 


\section{LISTA DE TABELAS}

Tabela 1- Genes não relacionados ao HLA implicados na patogênese da ES.

Tabela 2 - Índice de atividade de Valentini

Tabela 3 - Padronização da imunohistoquímica para detecção de caspase-3, ET-1, CGTF, TGF $\beta$ e VEGF

Tabela 4 - Oligonucleotídeos

Tabela 5 Características clínicas e laboratoriais dos pacientes cujas biópsias foram utilizadas para estudo histológico e para cultura de fibroblastos

Tabela 6 - Análise estatística da expressão dos colágenos I, III e V entre os grupos controle, doença precoce e doença tardia

Tabela 7 - Coeficientes de correlação entre a expressão dos colágenos I, III e V e o tempo de doença em meses.

Tabela 8 - Coeficientes de correlação entre espessamento cutâneo, atividade de doença e expressão de colágeno $\mathrm{V}$ na derme de pacientes com ES

Tabela 9 - Interação do COLV com duração da doença, espessamento cutâneo e índice de atividade de Valentini.

Tabela 10 - Análise estatística da expressão dos marcadores de apoptose e de ativação endotelial nas células endoteliais dérmicas dos grupos ES precoce, tardio e controle 
Tabela 11 - Correlação entre a expressão do colágeno $V$ na derme com os marcadores de apoptose e de ativação endotelial

Tabela 12 - Expressão do colágeno $V$ dérmico nos diferentes grupos de animais estudados

Tabela 13 - Expressão dos marcadores de apoptose e de ativação endotelial nas células endoteliais dérmicas de coelhos COLV-IM e de controles 


\section{LISTA DE GRÁFICOS}

Gráfico 1 - Quantificação por RT-PCR em tempo real dos genes das cadeias a dos colágenos V, I e III obtidos da cultura de fibroblastos dérmicos

Gráfico 2 - Expressão de COL V na derme de coelhos COL V-IM e de controles

Gráfico 3 - Expressão de caspase-3 nas células endotelais dérmicas de coelhos COL V-IM e de controles

Gráfico 4 - Expressão de ET1 nas células endoteliais dérmicas de coelhos COL V-IM e de controles.

Gráfico 5 - Expressão de CTGF nas células endoteliais dérmicas de coelhos COLV-IM e de controles.

Gráfico 6 - Expressão de TGF $\beta$ nas células endoteliais dérmicas de coelhos COLV-IM e de controles

Gráfico 7 - Expressão de VEGF nas células endoteliais dérmicas de coelhos COLV-IM e de controles. 


\section{RESUMO}

Martin P. Estudo da interação endotélio-matriz extracelular no remodelamento da pele observada no modelo experimental de esclerodermia e na enfermidade espontânea humana [tese]. São Paulo: Faculdade de Medicina, Universidade de São Paulo; 2012.

Introdução: A imunização de coelhos saudáveis com colágeno do tipo V (COLV) reproduz as principais manifestações da esclerose sistêmica (ES), incluindo fibrose, vasculopatia e produção de autoanticorpos específicos da doença. Estudos preliminares mostraram que, tanto na derme de animais imunizados com COLV (COLV-IM), como na derme de pacientes com ES, observa-se deposição aumentada de COLV anômalo, mas não se sabe qual a relevância clínica deste achado. O remodelamento da matriz extracelular é precoce nos animais COLV-IM, ocorrendo já no sétimo dia após a imunização, o que sugere que o COLV esteja relacionado com a injúria endotelial, evento primário envolvido na patogênese da ES. Desta forma, os objetivos do presente estudo foram avaliar a expressão de COLV na derme de controles saudáveis e de pacientes com ES e sua correlação com espessamento cutâneo, atividade e duração da doença; assim como pesquisar uma possível associação entre a deposição deste colágeno na derme com a expressão de marcadores de apoptose e de ativação endotelial em pacientes e no modelo animal induzido pela imunização com COLV. Pacientes e Métodos: Biópsias de pele de pacientes com ES ( $N=18,6$ com doença precoce e 12 com doença tardia) e de controles $(\mathrm{N}=10)$ pareados por idade e sexo, assim como biópsias de pele de coelhos imunizados com COLV + adjuvante de Freund (COV-IM, N=6) ou adjuvante de Freund $(\mathrm{N}=6)$ foram avaliadas. Nos pacientes com $\mathrm{ES}$, o espessamento cutâneo foi avaliado por meio do escore de Rodnan Modificado (MRSS) e a atividade da doença foi calculada pelo índice de atividade de Valentini. Para realizar a quantificação por histomorfometria, o COLV na derme foi identificado por imunofluorescência. Caspase-3, endotelina-1, CTGF, TGF $\beta$ e VEGF nas células endoteliais dérmicas foram marcados por 
imunohistoquímica. Nos pacientes e nos controles, o COLV proveniente da cultura de fibroblastos dérmicos foi quantificado por PCR - RT em tempo real e caracterizado por eletroforese, imunoblotting e reconstrução tridimensional, por meio da microscopia confocal. Resultados: O depósito de COLV foi maior na derme de pacientes com doença precoce, quando comparados aos controles e aos pacientes com doença tardia. A atividade e a duração da ES estiveram associadas com o depósito de COLV. A expressão de RNA mensageiro das cadeias COLVa $\mathrm{C}_{1} \mathrm{COLVa}_{2}$ foi aumentada em relação aos controles e a reconstrução tridimensional confirmou a presença de fibras anômalas de COLV. Observou-se maior expressão de caspase-3, endotelina-1, CTGF, TGF $\beta$ e VEGF nas células endoteliais dos pacientes com ES, quando comparados aos controles. Houve correlação positiva entre o depósito de COLV e a expressão de caspase-3, endotelina-1 e CTGF. Ao comparar-se os coelhos COLV-IM com os controles, observou-se aumento significativo da expressão de COLV aos 7 dias e de endotelina-1 aos 210 dias após a imunização. Embora de maneira não significativa, verificou-se maior expressão de caspase-3, CTGF e VEGF nos animais COLV-IM e, quando os animais foram comparados ao longo do tempo, percebeu-se maior expressão de COLV no sétimo dia após a imunização na derme dos animais COLV-IM, diminuindo no trigésimo dia e voltando a subir aos 75 dias e aos 210 dias. A caspase-3 e a endotelina-1 comportaram-se de maneira semelhante. Conclusão: Estes resultados sugerem que o COLV possa agir como um possível gatilho envolvido na patogênese da $E S$, agindo como um indutor de ativação e de apoptose endotelial, que por sua vez poderia resultar em maior expressão de COLV, perpetuando o processo de remodelamento observado na pele dos pacientes com ES.

Descritores: 1.Colágeno tipo V 2.Esclerose sistêmica 3.Derme 4.Células endoteliais 5.Apoptose 6.Modelos animais 


\section{SUMMARY}

Martin P. Study of endothelium - extracellular matrix interaction in skin remodeling observed in an experimental model of scleroderma and spontaneous human disease [thesis]. São Paulo: Faculdade de Medicina, Universidade de São Paulo; 2012.

Introduction: The immunization of healthy rabbits with type $V$ collagen (COLV) reproduces the main characteristics of systemic sclerosis (SSc), such as fibrosis, vasculopathy and specific auto-antibodies. Preliminary studies demonstrated that both COLV-immunized rabbits (COLV-IM) and SSc patients exhibit increased expression of abnormal COLV in the dermis, but the clinical relevance of this finding is unknown. The remodeling of the extracellular matrix is an early event in COLV-IM rabbits that can be detected by the seventh day after immunization; this observation suggests that COLV is involved in endothelial injury, one of the first manifestations of the disease. Thus, the objectives of this study were to evaluate COLV expression in the dermis of healthy controls and SSc patients and to determine the correlation of this expression with skin thickness, disease activity and duration and search for a possible association between this collagen with apoptosis and activation of endothelial cells markers in patients and in animal model induced by immunization with COLV. Patients and Methods: Skin biopsies from 18 patients (6 early-stage and 12 late-stage) and 10 healthy controls as well as skin biopsies from rabbits immunized with COLV (COLV-IM) and Freund adjuvant $(\mathrm{N}=6)$ or Freund adjuvant alone $(\mathrm{N}=6)$ were evaluated. Skin thickening assessment was performed with the Modified Rodnan Skin Score (MRSS), and activity was calculated using the Valentini Disease Activity Index. To perform quantification by histomorphometry, COLV was identified by immunofluorescence, and caspase-3, endothelin-1, CTGF, TGF $\beta$ and VEGF in dermal endothelial cells were labeled by immunohistochemistry. In SSc patients 
and healthy controls, COLV from dermal fibroblast culture was quantified by real-time RT-PCR and characterized by electrophoresis, immunoblotting and tridimensional reconstruction by confocal microscopy. Results: COLV deposition was increased in the dermis of the patients with early disease compared with the healthy controls and the patients with late disease. SSc activity and disease duration were associated with dermal COLV deposition. $\mathrm{COLVa}_{1}$ and $\mathrm{COLVa} \mathrm{a}_{2}$ mRNA expression levels were higher in SSc, and a tridimensional reconstruction of SSc dermal heterotypic fibers confirmed the presence of abnormal COLV. The dermal endothelial cell expression of caspase-3, endothelin-1, CTGF, TGF $\beta$ and VEGF was higher in the SSc patients than in the controls. There was a positive correlation between COLV deposition and caspase-3, endothelin-1 and CTGF expression. When the COLV-IM rabbits were compared with the controls, there was a significant increase in the expression of COLV 7 days after the immunization and a significant increase in the expression of endothelin-1 210 days after the immunization. The expression of caspase-3, CTGF and VEGF was higher in the COLV-IM animals than in the control rabbits, although not significantly, and when the rabbits were compared over time, the expression of COLV was higher in the dermis of the COLV-IM animals 7 days after immunization, decreasing at 30 days and increasing again at 75 and 210 days. Caspase- 3 and endothelin-1 exhibited similar behavior. Conclusion: these results suggest that COLV can be a possible trigger involved in the pathogenesis of SSc, acting as an inducer of endothelial apoptosis and activation that could result in higher expression of COLV, perpetuating the remodeling process observed in SSc skin.

Descriptors 1. Collagen type V 2. Systemic Sclerosis 3. Dermis 4. Endothelial Cells 5. Apoptosis 6. Animal Models 


\section{SUMÁRIO}

Lista de abreviaturas e siglas.................................................................................

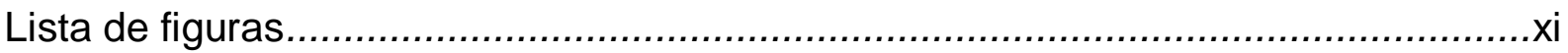

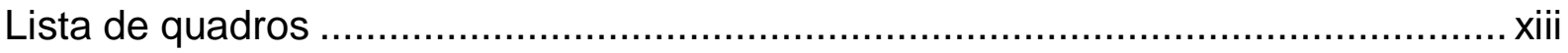

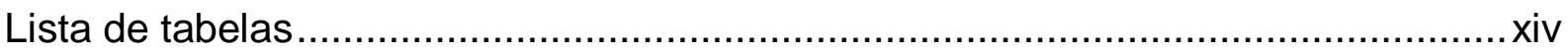

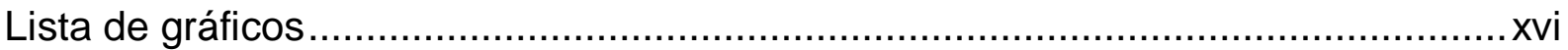

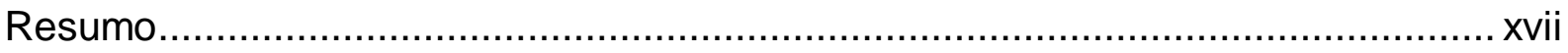

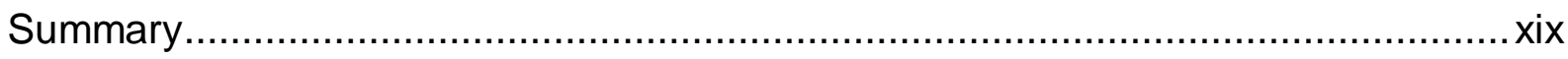

1 INTRODUÇÃO

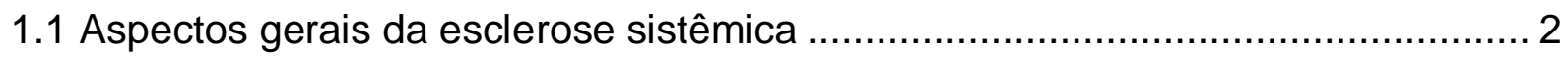

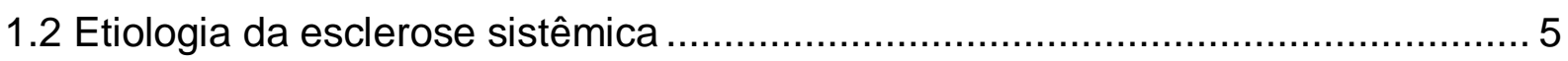

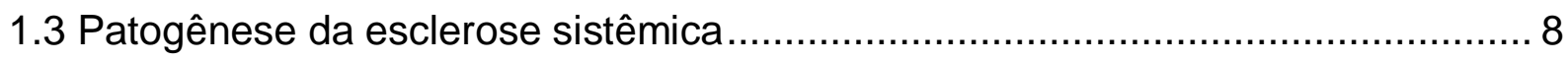

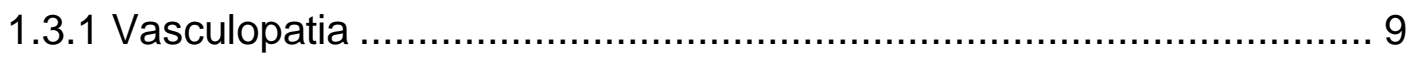

1.3.2 Alterações imunológicas ......................................................... 13

1.3.3 Depósito excessivo de matriz extracelular ..................................... 14

1. 4 Estrutura, função e biossíntese dos colágenos fibrilares ................................. 16

1. 5 A importância do colágeno $\mathrm{V}$........................................................................ 21

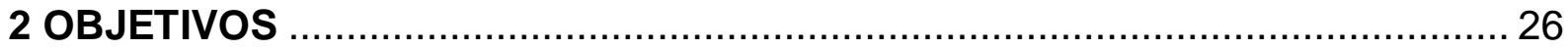

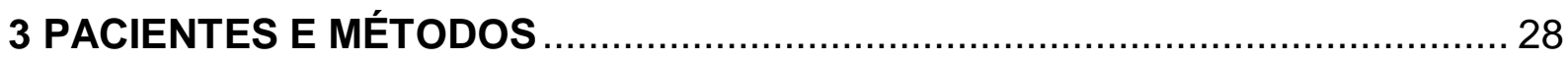

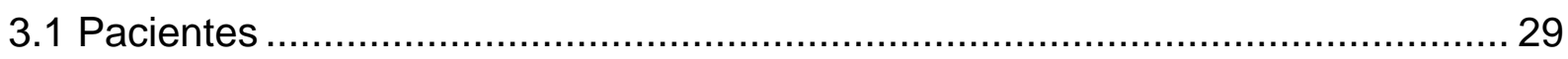

3.2 Modelo experimental de esclerose sistêmica induzido pela imunização

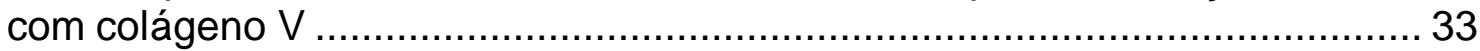

3.3 Imunofluorêcencia para os colágenos I, III e V na derme humana e do

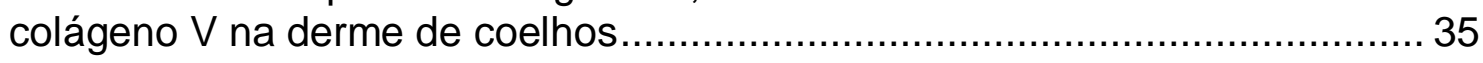

3.4 Histomorfometria dos colágenos I, III e V na derme humana e do colágeno $\mathrm{V}$ na derme de coelhos. 
3.5 Quantificação de caspase-3, ET1, TGFB, CTGF e VEGF nas células endoteliais de pacientes e controles com es e de coelhos COLV-IM e controles

3.5.1 Identificação das células endoteliais em apoptose

3.5.2 Imunohistoquímica para detecção de caspase-3, ET1, VCAM, CTGF,

TGF $\beta$ e VEGF nas células endoteliais

3.5.3 Histomorfometria da caspase-3, ET1, CTGF, TGF $\beta$ e VEGF nas

células endoteliais

3.6 Estudo da cultura de fibroblastos dérmicos provenientes de pacientes e controles

3.6.1 Cultura primária de fibroblastos dérmicos por explant

3.6.2 Imunomarcação dos colágenos I, III e $\mathrm{V}$ na cultura de fibroblastos.. 44

3.6.3 Extração de mRNA, transcrição reversa e PCR em tempo real ....... 46

3.6.4 Extração de colágeno, eletroforese em gel de poliacrilamida e immunoblot.....

3.7 Análise estatística

4 RESULTADOS

4.1 Caracterização dos pacientes e controles

4.2 Expressão dos colágeno I, III e $\mathrm{V}$ na derme de pacientes com doença precoce, doença tardia e controles

4.3 Correlação entre espessamento cutâneo, atividade de doença e expressão de colágeno $v$ na derme de pacientes com ES

4.4 Reconstrução tridimensional dos colágeno I, III e V na cultura de fibroblastos dérmicos

4.5 Expressão dos genes das cadeias alfa dos colágenos I, III e V obtidos da cultura de fibroblastos dérmicos

4.6 Eletroforese e immunoblot do colágeno $V$ extraído do sobrenadante da cultura de fibroblastos dérmicos

4.7 Quantificação de marcadores de apoptose e de ativação endotelial nas células endoteliais dérmicas de pacientes com ES e controles

4.8 Avaliação do modelo experimental de esclerose sistêmica induzido pela imunização com colágeno $\mathrm{V}$

4.8.1 Expressão do colágeno $\mathrm{V}$ na derme de animais COLV- IM e de animais controle

4.8.2 Expressão de marcadores de apoptose e de ativação endotelial na derme de animais COLV- IM e de controles 
6 CONCLUSÕES.

7 ANEXOS

Anexo A Termo de consetimento livre e esclarecido ............................................ 106

Anexo B Aprovação da CAPPesq .................................................................. 109

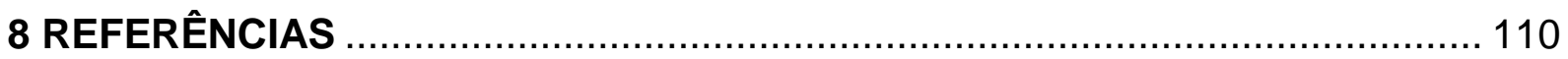

9 APÊNDICE: artigo "Abnormal collagen $v$ deposition in dermis correlates with skin thickening and disease activity in systemic sclerosis" in press. 
1 INTRODUÇÃO 


\subsection{Aspectos gerais da esclerose sistêmica}

A esclerose sistêmica (ES) é uma doença crônica, multissistêmica, caracterizada por depósito excessivo de colágeno na pele e em órgãos internos, vasculopatia e alterações imunológicas (Seibold, 2001).

Esta doença é classificada nas formas limitada ou difusa, tendo como base a extensão do envolvimento cutâneo. Pacientes com doença difusa apresentam espessamento da pele da face, tronco, abdome e porção proximal dos membros. Nestes pacientes, a evolução da doença é rápida e, além do acometimento cutâneo, ocorre doença pulmonar intersticial e há risco aumentado de crise renal esclerodérmica. Além disso, nesta forma de doença, é comum a presença de anticorpos antitopoisomerase (Seibold, 2001).

$\mathrm{Na}$ forma limitada, o espessamento cutâneo geralmente se restringe às mãos e à face, podendo envolver a pele distal aos cotovelos e aos joelhos. Nestes pacientes são comuns manifestações como telangiectasias, calcinose e hipertensão pulmonar, assim como a presença de anticorpos anticentroméricos. Nas duas formas de doença, pode ocorrer envolvimento do trato gastrointestinal, sendo a dismotilidade esofágica a manifestação mais comum (Seibold, 2001).

Finalmente, chama a atenção o fenômeno de Raynaud, presente tanto na forma limitada como na forma difusa. Constitui-se a manifestação 
clínica mais precoce da ES, precedendo o espessamento cutâneo por anos, na forma limitada, e por um menor intervalo de tempo, na forma difusa, denotando a importância da vasculopatia como evento inicial na patogênese da doença (Wigley, 2009).

A extensão do acometimento cutâneo parece ser um fator prognóstico, já que estudos recentes mostraram que a doença difusa é um preditor independente de menor sobrevida (Czirják, 2008; Al-Dhaher, 2010; Joven, 2010). Além disso, a maior morbidade está associada com a extensão do espessamento cutâneo, já que é possível observar melhora da função nas mãos quando existe amolecimento da pele, após tratamento ou evolução natural da enfermidade (Clements, 2000; Seibold, 2000).

A prevalência da ES é estimada entre 3 e 24 casos por 100 mil habitantes, variando de acordo com a etnia e a localização geográfica, sendo que é maior na América do Norte e na Austrália em relação à Europa e ao Japão (Ranque, 2010). Na América Latina, existe apenas um estudo, realizado em Buenos Aires, mostrando prevalência da ES semelhante à da América do Norte (29,6 casos por 100 mil habitantes) (Rosa, 2011); ainda não há dados disponíveis sobre a prevalência desta doença no Brasil, mas no estudo epidemiológico GEPRO estes dados estão sendo compilados. Vários trabalhos realizados nos Estados Unidos sugerem que a ES é mais comum em negros (Ranque, 2010), iniciando-se mais cedo nesta raça. Em relação ao sexo, é mais frequente em mulheres, variando de 1 a 14/1, com média de 3/1 (Ranque, 2010), o que pode ser atribuído à exposição 
ambiental e à fatores hormonais. Quanto à idade, a ES pode ocorrer em qualquer idade, mas é rara na infância e em pacientes muito idosos, sendo mais comum na quinta década (Ranque, 2010).

Apesar de rara, a ES é uma doença de extrema importância, apresentando pior prognóstico quando comparada a outras doenças reumatológicas, devido a fatores como índice de mortalidade elevado (4 a 5 vezes maior do que na população saudável com a mesma idade e sexo), comprometimento da qualidade de vida, incapacidade e alto impacto do ponto de vista econômico (Ferri, 2002; Hudson, 2009; Silman 1997; Schnitzer, 2011 Sharif, 2011). De fato, em países da Europa, o custo médio estimado do gasto com a doença gira em torno de 9600 a 11000 euros/paciente/ano (Minier, 2010b; Belotti, 2003) e, na América do Norte, varia de US\$14.959/paciente/ano nos Estados Unidos a 18.453 dólares canadenses/paciente/ano (Nietert, 2001; Bernatsky, 2009). Grande parte deste montante deve-se a custos indiretos ligados à incapacidade causada pela doença e à consequente perda de produtividade (Minier, 2010b). Infelizmente, não se dispõe de dados sobre o custo da ES no Brasil. 


\subsection{Etiologia da esclerose sistêmica}

A etiologia da ES ainda não foi determinada, mas estudos epidemiológicos sugerem a contribuição de alterações genéticas e de fatores ambientais (Allanore, 2007). Dentre os componentes genéticos, o complexo maior de histocompatibilidade (MHC) parece ter importância na etiologia da ES, já que estudos imunogenéticos sugerem que os genes do MHC influenciam a expressão de autoanticorpos (Kuwana, 1999; Reveille 2001). Em pacientes com ES, observa-se maior frequência de alelos e de haplótipos pertencentes ao HLA classe II, incluindo os haplótipos DRB1*1104, DQA1*0501, DQB1*0301e os alelos DQB126*epi. Por outro lado, os haplótipos DRB1 ${ }^{*} 0701, \mathrm{DQA} 1{ }^{*} 0201, \mathrm{DQB} 1{ }^{*} 0202$, DRB1 ${ }^{*} 1501$ estão negativamente correlacionados com a doença e possivelmente exerçam papel protetor (Arnet, 2010). Além desses, outros genes não relacionados ao HLA, listados na tabela 1, conferem maior suscetibilidade à ES, codificando proteínas com papel relevante na patogênese desta doença. 
Tabela 1 - genes não relacionados ao HLA implicados na patogênese da ES

\begin{tabular}{ll}
\hline \multicolumn{1}{c}{ Lócus } & Contribuição na patogênese da esclerose sistêmica \\
\hline PTPN22 & $\begin{array}{l}\text { Codifica uma proteína tirosina-fosfatase intracelular } \\
\text { envolvida na sinalização tanto dos linfócitos T como } \\
\text { dos linfócitos B (Gourh, 2006; Dieude, 2008). }\end{array}$ \\
IRF5 & $\begin{array}{l}\text { Codifica fator de transcrição envolvido na ativação do } \\
\text { Interferon-1 (Diude, 2009a; Ito, 2009; Diude, 2010). }\end{array}$ \\
STAT4 & Codifica fator de transcrição envolvido na sinalização \\
& $\begin{array}{l}\text { dos receptores da IL-12 e IL-23 (Rueda, 2009; Dieude, } \\
\text { 2009b; Gourh, 2009). }\end{array}$
\end{tabular}

BANK1 Codifica proteína envolvida na sinalização dos linfócitos B (Dieude, 2009c; Rueda, 2010).

C8orf13-BLK Codifica uma proteína linfócito B quinase (BLK) que está envolvida na sinalização dos linfócitos B (Gourh, 2010a; Ito, 2010).

TNFSF4 Codifica ligante envolvido na co-estimulação dos linfócitos T (Gourh, 2010b).

Apesar destas associações gênicas terem sido reproduzidas em diferentes centros, incluindo populações distintas, estudo com gêmeos homozigóticos mostrou baixo nível de concordância para o desenvolvimento da ES (Feghali, 2003), confirmando a importância dos fatores ambientais em sua etiologia. De fato, estudos epidemiológicos suportam a relação entre a exposição a certos agentes e o desenvolvimento da doença, incluindo 
agentes químicos como a sílica, o benzeno, o tolueno, o tricloroetileno, o hexacloroetano, além de drogas como a bleomicina, a pentazocina e o Ltriptofano (Nietert 2000). Entretanto, o mecanismo patológico pelo qual estes fatores induzem a doença é desconhecido (Nietert 2000).

A participação de agentes infecciosos tais como parvovírus B19, citomegalovirus (CMV), vírus Epstein-Bar (EBV) e bactérias na etiologia da ES, tem sido estudada exaustivamente e mecanismos imunopatogênicos foram propostos para explicar como estes agentes poderiam desencadear a doença. Dessa forma, foi demonstrado que 57\% a $79 \%$ (Ferri, 1999; Zakrzewska, 2009) dos pacientes com ES apresentam partículas de DNA de parvovírus B19 na medula óssea, que constitui um reservatório a partir da qual este vírus se espalha para os tecidos periféricos, infectando as células endoteliais (Cassinoti, 1997). O grau de expressão de RNA mensageiro (mRNA) de parvovírus B19 nestas células está diretamente relacionado ao grau de injúria endotelial e de infiltrado inflamatório perivascular (Magro, 2004). Em relação ao CMV, sabe-se que este vírus é capaz de infectar células endoteliais e macrófagos, levando à produção de citocinas prófibróticas e de integrinas (Pandey, 1998; Shahgasempour, 1997). Além disso, anticorpos direcionados contra o peptídeo UL94, presente neste vírus, causam apoptose de células endoteliais (Lunardi, 2000).

Pacientes com ES apresentam maior reatividade sorológica para Helicobacter pylori (Kalabay 2002), cujos produtos extracelulares poderiam 
desencadear resposta inflamatória, levando à ativação de fibroblastos e à injúria endotelial (Grossman , 2011).

O microquimerismo, fenômeno caracterizado pela sobrevivência de linfócitos $\mathrm{T}$ alotípicos, desencadeado tanto pela passagem de células maternas aos filhos como de células fetais para a mãe durante a gravidez, ou recebidas em transfusões de sangue, também é considerado uma possível causa de ES. Uma vez ativadas por vírus ou agentes químicos, estas células microquiméricas seriam capazes de reconhecer antígenos no hospedeiro e desencadear uma resposta imunológica com liberação de citocinas pró-inflamatórias, resultando nas alterações fibro-proliferativas e vasculares características da ES (Jymenez, 2005).

\subsection{Patogênese da esclerose sistêmica}

A patogênese da ES resulta da interação entre vasculopatia, disfunção imunológica e deposição excessiva de matriz extracelular na pele e nos órgãos internos. Estes três mecanismos patogênicos estão fortemente correlacionados, uma vez que ocorre interação entre células endoteliais, células mononucleares e fibroblastos, o que leva ao remodelamento vascular e tecidual presente na ES (Le Roy, 1988). 


\subsubsection{Vasculopatia}

O fenômeno de Raynaud é a manifestação clínica mais precoce da ES, podendo preceder o espessamento cutâneo por meses ou anos (Wigley, 2009). De forma semelhante, estudos histopatológicos confirmam que alterações funcionais das células endoteliais antecedem a fibrose (Prescott, 1992). Presentes na interface entre o sangue e o tecido, as células endoteliais estão criticamente envolvidas na manutenção da homeostase vascular, regulando o tônus, a permeabilidade, a coagulação e o envio de células imunes para os tecidos (Lin, 2010). Uma vez expostas a estímulos nocivos, estas células passam por modificações fenotípicas, resultando em maior expressão de endotelina-1 (ET1), de moléculas de adesão e de fatores de crescimento, evento conhecido por ativação endotelial (Abraham, 2007; Lin, 2010; Murdaca, 2012).

A ET1 é um peptídeo, com potente ação vasoconstrictora, que aparece aumentado no soro (Yamane, 1991) e na pele de pacientes com ES (Vancheeswaran, 1994a). A ET1 exerce seus efeitos por meio do receptores da endotelina tipos A (ETA) e tipo B (ETB), causando vasoconstrição, proliferação celular e remodelamento vascular (Luscher, 1990; Murakosi 2002). Nos vasos normais, estas ações ocorrem pela ativação dos receptores ETA, enquanto a ativação dos receptores ETB resulta na liberação de vasodilatadores e na remoção da ET1 (Verhaar, 1998). Entretanto, em condições patológicas, os receptores ETB perdem a sua 
função e passam a estimular a síntese de matriz extracelular (Shi-Wen, 2006). Assim, a ET1 também desempenha importante ação pró-fibrótica, tanto é que os níveis séricos de ET1 estão elevados não só em pacientes com hipertensão pulmonar ou crise renal esclerodérmica, mas também em pacientes com doença cutânea difusa ou fibrose pulmonar (Vancheeswaran, 1994b). De fato, a ET1 induz a mudança fenotípica de fibroblastos para miofibroblastos (Shi-Wen, 2004a), a expressão gênica do fator de crescimento do tecido conjuntivo (CTGF) (Shi-Wen, 2004b) e promove a síntese de colágeno dos tipos I (COLI) e III (COLIII) pelos fibroblastos (Horstmeyer, 2005; Shi-Wen, 2001).

As moléculas de adesão são proteínas envolvidas na interação célulacélula e célula-matriz extracelular (Wigley, 2009) sendo expressas por células endoteliais ativadas (Abraham, 2007; Lin, 2010). Estas moléculas permitem a interação entre leucócitos e fibroblastos e o aporte de linfócitos para os tecidos (Gruschwitz, 1992). Quando comparadas a controles saudáveis, as células endoteliais da pele de pacientes com ES apresentam maior expressão de molécula de adesão endotélio-leucócito-1 (ELAM-1), de molécula de adesão intercelular-1 (ICAM-1), de molécula de adesão vascular-1 (VCAM -1) e de E-selectina (Sollberg, 1992; Gruschwitz, 1995). Estas moléculas de adesão também estão elevadas no soro dos pacientes com ES (Denton, 1995; Gruschwitz, 1995; Ihn, 1997; Ihn, 1998; Kiener 1994; Sfikakis,1993; Sondergaard, 1998; Veale, 1998) e, notadamente, existe correlação entre os níveis séricos de E-selectina, de ICAM-1 e de VCAM-1 e 
a gravidade da ES (Ihn, 1997; Denton, 1995; Sfikakis,1993). As moléculas de adesão desempenham múltiplas funções na patogênese da ES, levando ao acúmulo de leucócitos nos tecidos (Abraham, 1991; Rudnicka, 1992), os quais, uma vez ativados, passam a liberar citocinas pró-fibróticas, resultando na síntese excessiva de matriz extracelular (Sato, 1999).

Dentre os fatores de crescimento produzidos pelas células endoteliais ativadas, destacam-se o fator de crescimento beta (TGF $\beta$ ) e o CTGF (Phan, 2001; Yin, 2011), citocinas-chave na patogênese da ES (Pannu, 2004). Notadamente, no modelo animal de fibrose pulmonar induzido por bleomicina, já no sétimo dia após a instilação da droga, ocorre maior expressão de TGF $\beta$ e CTGF nas células endoteliais, resultando no aumento da síntese de COLI, sendo que apenas no $14^{\circ}$ dia após a instilação estes fatores de crescimento passam a ser produzidos pelos fibroblastos, comprovando a importância das células endoteliais na iniciação do processo fibrótico (Yin, 2011).

Outro importante fator de crescimento expresso pelas células endoteliais ativadas é o fator de crescimento endotelial vascular (VEGF), (Avouac, 2008) que está aumentado na pele (Davies, 2006; Distler, 2004; Mackiewicz, 2002) e no soro de pacientes com ES (Kikuchi, 1998; Papaioannou, 2009; Distler 2002). Apesar de apresentar importantes propriedades pró-angiogênicas, a indução de redes vasculares por este fator de crescimento não é suficiente para produzir vasculatura permanente, sendo que novos vasos induzidos pelo VEGF tendem a desaparecer 
(Fleming, 2008). Adicionalmente, a exposição prolongada ao VEGF resulta na formação de vasos sanguíneos de formato irregular e com fluxo reduzido, muito semelhantes aos megacapilares dos pacientes com ES (Dor, 2002).

Além da ativação das células endoteliais, outro importante mecanismo responsável pela vasculopatia da ES é a apoptose destas células, evento observado precocemente na derme de pacientes com ES, durante a fase edematosa e inflamatória da doença (Sgonc, 1996), mediado por anticorpos anticélulas endoteliais (Bordron, 1996; Sgonc, 2000; Worda, 2003). A apoptose destas células é um importante mecanismo de doença, pois leva ao destacamento delas da parede dos vasos, resultando em perda da função de barreira e causando edema e exposição da matriz sub-endotelial (Jun, 2003). Uma vez em apoptose, as células endoteliais aumentam a adesão para plaquetas e leucócitos (Bombeli, 1999; Schwartz, 1999), induzem fenótipo antiapoptótico em fibroblastos (Laplante, 2005) e passam a produzir CTGF, que perpetua o depósito de colágeno (Laplante, 2010).

Defeitos na angiogênese (formação de novos vasos a partir da diferenciação de células endoteliais de vasos pré-existentes) e na vasculogênese (formação de novos vasos a partir de células progenitoras endoteliais) (Rissau, 1992, Rissau 1997; Manetti, 2010), assim como a presença de fatores que inibem a angiogênese, tais como endostatina, metaloproteinase matricial-12, kalicreínas e plasminogênio intacto e de seus fragmentos, acentuam ainda mais a vasculopatia, resultando em rarefação 
capilar (Distler, 2002; Hebbar, 2000; Mulligan, 2007; D’ Alessio, 2004; Del, 2005).

\subsubsection{Alterações imunológicas}

Alterações na imunidade celular e humoral estão envolvidas na patogênese da ES. Precocemente na derme de pacientes com ES, observase infiltrado de células T, ocorrendo antes da fibrose (Sakkas, 2002). Notadamente, este infiltrado é oligoclonal, denotando que estas células são estimuladas por um antígeno específico ainda desconhecido (Sakkas, 2002), resultando em uma resposta imunológica do tipo Th2 (Sakkas, 2004). Neste tipo de resposta, os linfócitos T produzem interleucina-4 (IL-4), citocina, que estimula a proliferação celular, quimiotaxia, síntese de colágeno e produção de TGF- $\beta$ (Postlethwaite, 1992). Além disso, há produção de interleucina-17 (IL-17), que estimula a proliferação dos fibroblastos e a expressão de moléculas de adesão pelas células endoteliais (Kurasawa, 2000).

Os anticorpos antitopoisomerase e anticentromérico são marcadores específicos da ES, mas, apesar de apresentarem associação com os subtipos de doença, seu papel fisiopatogênico ainda não foi estabelecido (Varga, 2007). Entretanto, anticorpos voltados contra células endoteliais causam apoptose (Sgonc, 2000) e induzem a expressão de moléculas de adesão (Carvalho, 1996; Henaul, 2006), enquanto anticorpos direcionados 
ao receptor do fator de crescimento derivado de plaquetas (PDGF) induzem a síntese de colágeno em fibroblastos (Baroni, 2006).

\subsubsection{Depósito excessivo de matriz extracelular}

O depósito excessivo de matriz extracelular, principalmente de COLI e COLIII, é a manifestação mais característica da ES (Varga, 2007). Esta substituição progressiva da arquitetura tecidual normal por uma matriz extracelular rica em colágeno é definida como fibrose, processo considerado irreversível e que resulta na perda de função dos tecidos (Quinones, 1986).

Estes colágenos são produzidos pelos fibroblastos e pelos miofibroblastos, que, por sua vez, são ativados por citocinas e fatores de crescimento de maneira autócrina, parácrina ou ainda pela interação célulacélula ou célula-matriz extracelular (Varga, 2007). Dentre os fatores de crescimento, o TGF $\beta$ é considerado o principal regulador da fibrilogênese (Pannu, 2004), sendo sintetizado por plaquetas, linfócitos $T$, fibroblastos (Blobe, 2000) e células endoteliais (Phan, 1991). Este fator de crescimento induz síntese de colágeno, proliferação, migração, adesão e mudança fenotípica de fibroblastos para miofibroblastos (Blobe, 2000; Horstmeyer, 2005). A ligação do TGFß ao seu receptor resulta na fosforilação do SMAD2 e do SMAD3, que formam heterocomplexos com o SMAD4, alcançando o núcleo no qual recrutam co-fatores transcricionais (Massagué, 2006). Esta 
transdução de sinais é controlada por inibidores endógenos, tais como o SMAD7 (Mori, 2003). Outros mecanismos de sinalização intracelular diferentes da via mediada pelas SMAD's também são ativados pela ligação do TGF $\beta$ ao seu receptor, tais como as proteínas quinases e fosfatase calcineurina cálcio dependente (Moustakas, 2005).

Algumas das ações pró-fibróticas do TGF $\beta$ são mediadas pelo CTGF (Grotendorst, 1997), cuja expressão está aumentada na pele (Igarashi,1995) e no soro de pacientes com ES (Sato, 2000). Estudos realizados in vitro mostram que este fator de crescimento estimula a mitose, a quimiotaxia e a proliferação dos fibroblastos, além da produção de vários componentes da matriz extracelular, tais como COLI e fibronectina (Frazier, 1996).

A expressão gênica do CTGF é induzida principalmente pelo TGF $\beta$, mas outros fatores parecem estimular a síntese de CTGF, já que em células mesangiais houve expressão de CTGF na ausência de níveis elevados de TGF $\beta$ (Riser, 2000). Além disso, foi demonstrado que a ET1 induz a expressão de CTGF em fibroblastos (Shi-Wen, 2004b) e em células musculares lisas (Rodriguez-Vita, 2005), enquanto a hipóxia induz a expressão deste mediador em células endoteliais (Samarin, 2010).

Em resumo, acredita-se que em indivíduos geneticamente predispostos, diferentes agentes ambientais poderiam induzir injúria endotelial inicial, que resultaria não apenas em apoptose destas células, mas também em sua ativação, levando à liberação de mediadores com efeitos vasoconstritores e pró-fibróticos, assim como de moléculas de 
adesão, as quais permitiriam o aporte de células inflamatórias do sangue para o espaço extracelular. Linfócitos $\mathrm{T}$ reconheceriam algum antígeno específico, ainda desconhecido, iniciando uma resposta do tipo Th2, com liberação de IL-4, que levaria à produção de autoanticorpos e TGF $\beta$, resultando na síntese excessiva de colágenos pelos fibroblastos, com consequente remodelamento vascular e dos tecidos.

\section{4 Estrutura, função e biossíntese dos colágenos fibrilares}

As características biomecânicas dos tecidos resultam da organização dos colágenos em macromoléculas, que fornecem não apenas suporte, mas apresentam importante papel funcional, determinado pelos seus domínios proteicos adicionais (Gelse, 2003). Para o estudo da ES, o COLI, o COLIII e o colágeno do tipo V (COLV) são os mais importantes, já que são colágenos formadores de fibras (ou fibrilares) e estão presentes nos órgãos comumente afetados pela doença (Gelse, 2003).

A principal característica da molécula de colágeno é a sua estrutura longa e rígida, formada pelo entrelaçamento de três cadeias polipeptídicas, denominadas cadeias alfa. Os colágenos são extremamente ricos em prolina e glicina, importantes na formação da tripla hélice helicoidal. Devido a sua estrutura em anel, a prolina estabiliza a conformação da hélice em cada 
cadeia alfa, enquanto a glicina é espaçada regularmente a cada dois aminoácidos por toda região central da cadeia alfa. Por ser o menor aminoácido, a glicina permite que as três cadeias alfa se agrupem firmemente para formar a tripla hélice final do colágeno (Alberts, 2010). A estrutura da molécula de colágeno pode ser visualizada na figura 1.

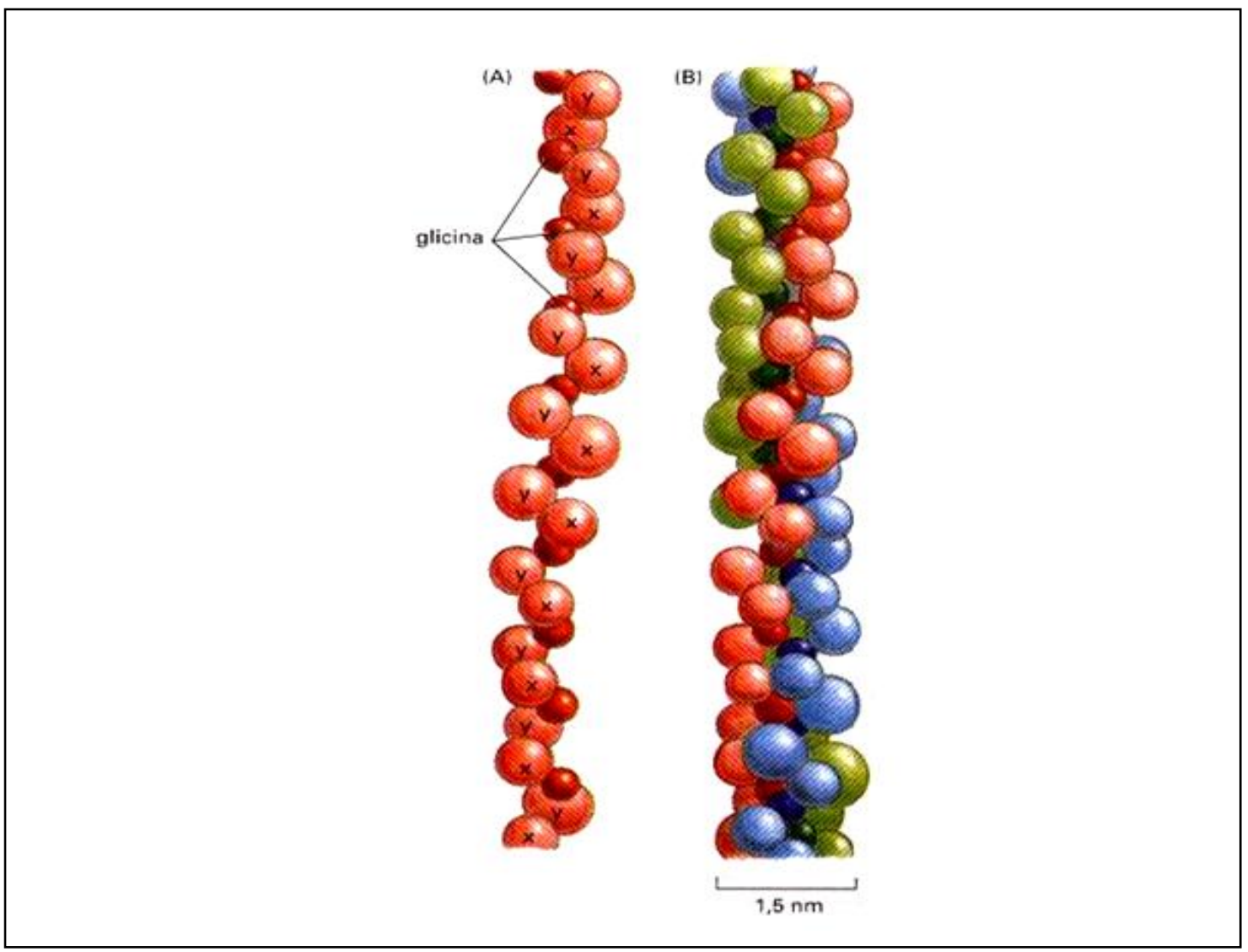

Figura 1 - Estrutura de uma molécula típica de colágeno. (A): Modelo de uma cadeia alfa, no qual cada aminoácido é representado por uma esfera. A cadeia é organizada em forma de uma hélice para a esquerda, contendo três aminoácidos, sendo que o terceiro é sempre uma glicina e $\mathrm{X}$ e $\mathrm{Y}$ quaisquer outros aminoácidos, porém geralmente $\mathrm{X}$ é uma prolina e $\mathrm{Y}$ uma hidroxiprolina. (B). Modelo de uma molécula de colágeno na qual as três cadeias alfa, representadas uma de cada cor, são enroladas umas nas outras, formando a tripla hélice. FONTE: Alberts, 2010.

A biossíntese dos colágenos é um processo complexo que envolve vários passos, iniciando-se no núcleo com a transcrição gênica, em geral 
estimulada por fatores de crescimento, tais como o TGF $\beta$ (Gelse, 2003). Após a tradução, as moléculas de pró-colágeno sofrem várias modificações no retículo endoplasmático rugoso, tais como hidroxilação dos resíduos de prolina e de lisina e posterior glicação dos resíduos de hidroxilisina. A hidroxilação da prolina é fundamental para a formação das pontes intramoleculares de hidrogênio, enquanto a hidroxilisina é necessária para as ligações cruzadas intermoleculares. Estas pontes ou ligações cruzadas podem ser observadas na figura 2. Ainda no retículo endoplasmático rugoso, as três cadeias alfas entrelaçam-se por meio de seus pró-peptídeos carboxiterminais. As moléculas em forma de tripla hélice são então empacotadas no complexo de Golgi e secretadas. Uma vez no meio extracelular, as terminações amino e carboxi-terminais dos pró-colágenos dos tipos I e III são removidas, entretanto são mantidas no COLV. Finalmente, os COLI, COLIII e COLV agregam-se formando estruturas fibrilares, que são estabilizadas pelas ligações cruzadas intermoleculares, permitindo a formação de uma rede estável. Estas estruturas formadas pela interação dos COLI, COLIII e COLV constituem as fibras heterotípicas (Gelse, 2003; Alberts, 2010). Na figura 3, podem ser observados os passos da síntese dos colágenos fibrilares. 


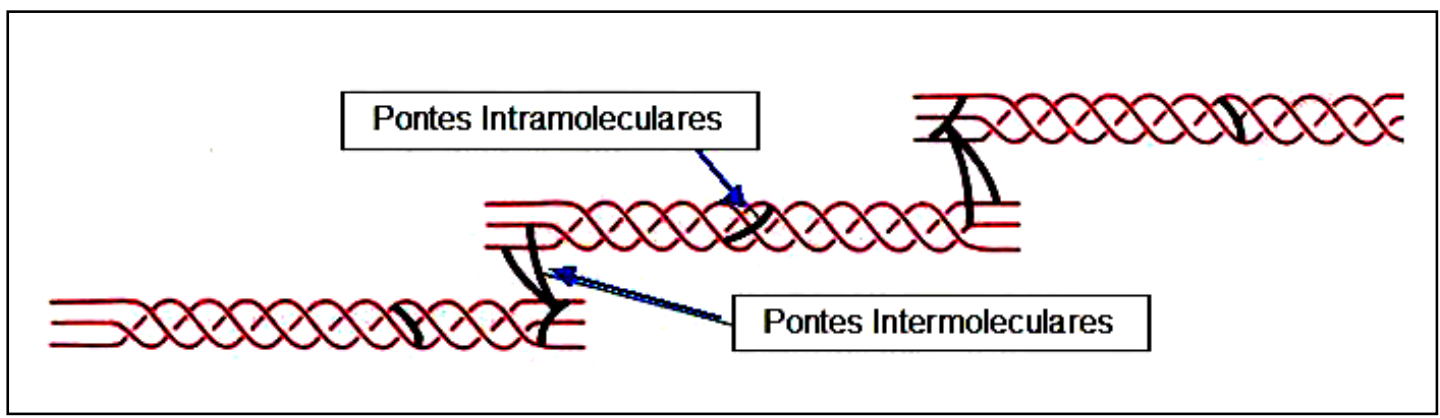

Figura 2 - Pontes intra e intermoleculares dos colágenos fibrilares. Estas pontes resultam da hidroxilação da prolina e da lisina, respectivamente, e são importantes para a manutenção das propriedades físicas e da estabilidade da molécula de colágeno. FONTE: Alberts, 2010. 


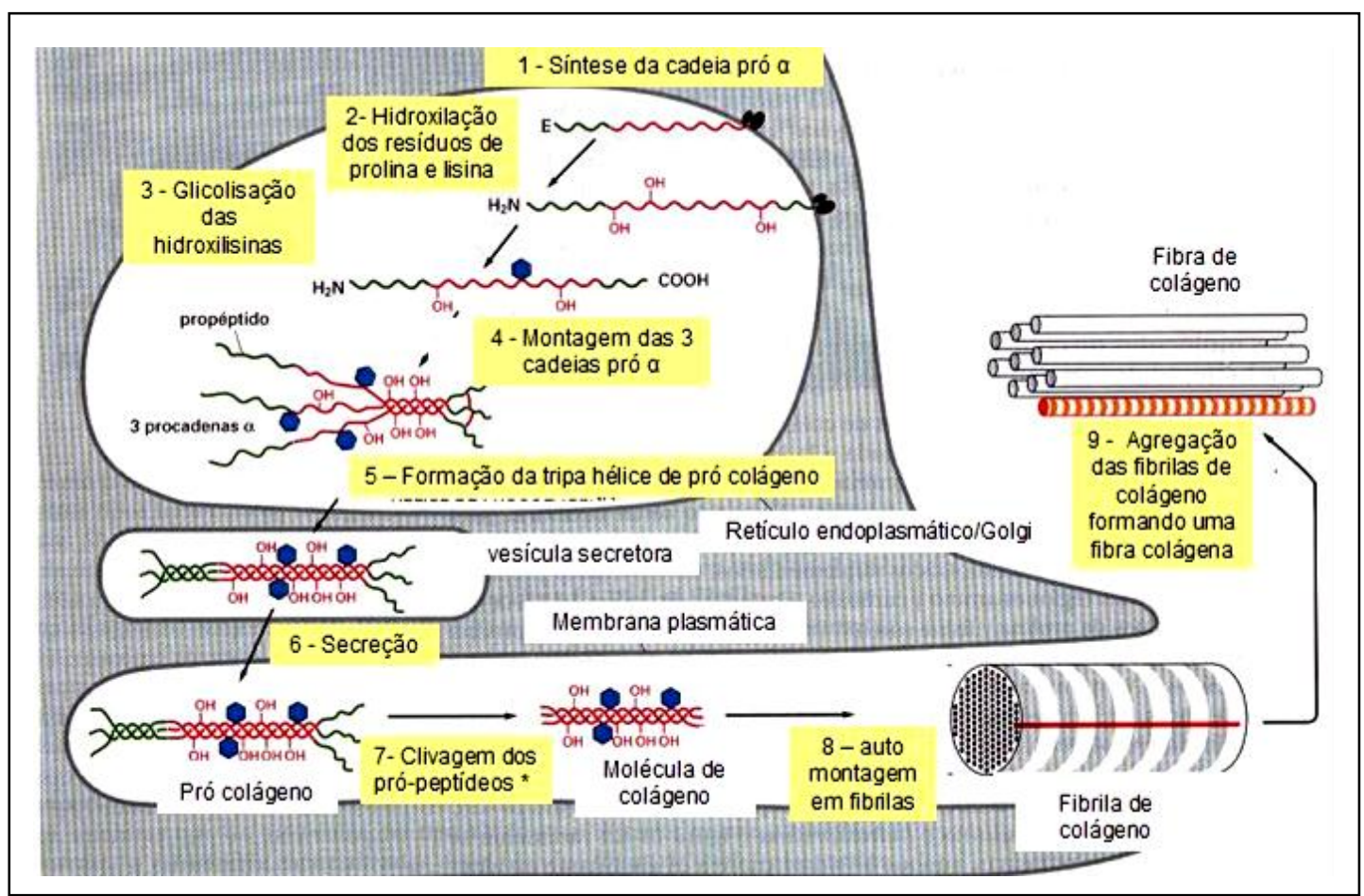

Figura 3 - Diagrama esquemático mostrando a biossíntese dos colágenos fibrilares. A cadeia pró-alfa é sintetizada no lúmen do retículo endoplasmático (1). Posteriormente, esta cadeia sofre hidroxilação de alguns resíduos de prolina e de lisina (2). Em seguida, as hidroxilisinas sofrem glicação ou glicolisação (3) e as três cadeias pró-alfa entrelaçam-se (4) formando a tripla hélice de pró-colágeno (5), que é empacotado no complexo de Golgi e secretado (6). Já no espaço extracelular, os pró-peptídeos amino e carboxi-terminal dos colágenos I e III são clivados (7) e as moléculas recém-formadas de colágeno agregam-se, formando as fibrilas (8) que, por sua vez, unem-se formando as fibras colágenas (8). FONTE: Alberts, 2010. 


\section{5 A importância do colágeno do tipo V}

O COLV representa apenas $1 \%$ a $3 \%$ do colágeno total da derme (Chanut-Delalande, 2001), mas apesar de presente em pequenas quantidades, devido às suas características peculiares, tem importância fundamental na manutenção das propriedades fisiológicas dos tecidos, pois controla o diâmetro das fibras heterotípicas. Sua tripla hélice, formada por duas cadeias alfa $1\left(\alpha_{1}\right)$ e uma cadeia alfa $2\left(\alpha_{2}\right)$, encontra-se oculta entre as fibras de COLI e de COLIII. Conforme exposto acima, diferentemente destes colágenos, o COLV conserva seu domínio amino terminal, que se projeta para a superfície da fibra heterotípica (Birk, 1990; Birk, 2001). À medida que estes domínios atingem uma concentração crítica, a agregação de novas moléculas de colágeno à superfície torna-se menos favorável do que a formação de novas fibrilas (Birk, 1990; Birk, 2001) (figura 4).

A importância deste colágeno no controle da síntese das fibras heterotípicas foi demonstrada não apenas em estudos in vitro (Birk, 1990; Chanut-Delalande, 2001), mas também por meio do estudo de animais transgênicos com deleção de sua cadeia $\alpha_{1}$. Os animais homozigotos evoluem a óbito por volta do $10^{\circ}$ dia de vida embrionária (Wenstrup, 2004), enquanto os animais heterozigotos apresentam menor densidade de fibras colágenas na derme, assim como a presença de fibras heterotípicas grossas, o que resulta em uma derme hiper-extensível, semelhante à derme 
dos pacientes com síndrome de Ehlers-Danlos (Wenstrup, 2006). Além disso, na maioria dos pacientes com a forma clássica desta síndrome, ocorrem mutações nas cadeias $\alpha_{1}$ ou $\alpha_{2}$, acarretando a produção de COLV estruturalmente anormal, disfuncional e em quantidade diminuída. Todas estas alterações se refletem clinicamente na presença de cicatrizes atróficas e de pele aveludada e hiper-extensível (Callewaert, 2008). 
A

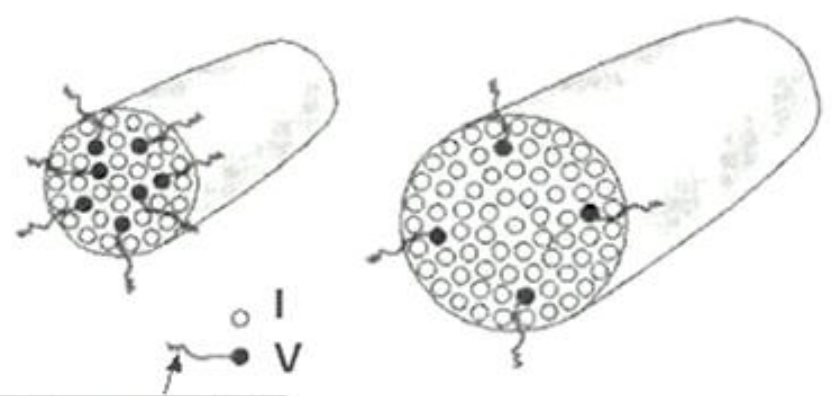

Dominio amino terminal

B
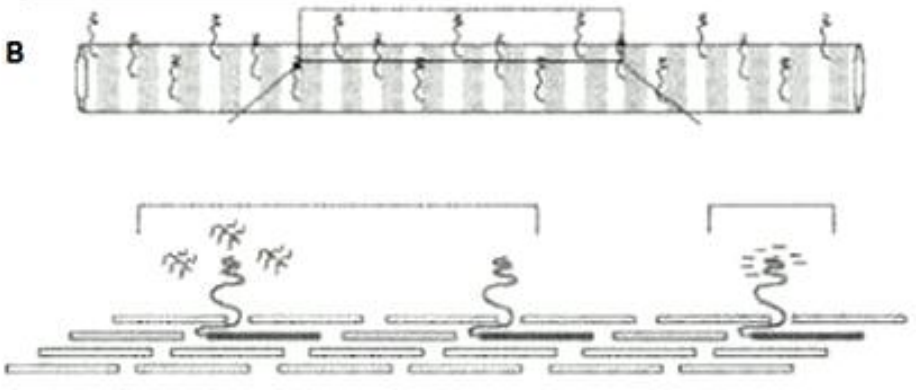

Dominio amino terminal

$\longrightarrow 1$

Figura 4: Desenho esquemático da interação dos colágenos I e $\mathrm{V}$ nas fibrilas heterotípicas. (A): Visão transversal mostrando fibrilas heterotípicas finas (à esquerda) e grossas (à direita). O COLV tem função na regulação do diâmetro das fibrilas heterotípicas, pois quando se encontra em maior proporção as fibrilas são mais finas e em menor proporção estas são mais grossas. (B): Visão longitudinal da fibrila heterotípica, mostrando que a tripla hélice do COLV fica oculta entre as fibras de COLI, enquanto seu domínio globular amino terminal se projeta para a região externa, impedindo fisicamente a agregação de novas moléculas de colágeno às fibrilas heterotípicas.

Além de sua função de controlar o diâmetro das fibras heterotípicas, o COLV possui outras propriedades biológicas. Nesse sentido, foi demonstrado que meio de cultura rico em COLV inibe o crescimento e a proliferação das células endotelias (Fukuda, 1998; Ziats, 1993). De fato, este colágeno induz apoptose de células endoteliais e tumorais pela 
fragmentação do DNA e a ativação das caspases (Pucci Minafra, 2000; Luparello,2003; Luparello,2005; Souza, 2010).

Considerando-se que o COLV mantém-se oculto dentro das fibras heterotípicas (Gelse, 2003), uma vez expostos seus epítopos poderiam funcionar como neo-antígenos, ativando o sistema imune. Numerosos estudos indicam que o COLV está envolvido nos processos de rejeição crônica e aguda ao transplante pulmonar, desencadeando resposta imunológica do tipo Th1 e via IL-17 (Bharat, 2006; Burlingham, 2007, Haque, 2002), assim como produção de autoanticorpos (Fukami, 2009). Notadamente, em modelo animal de rejeição ao enxerto pulmonar, a indução de tolerância oral ao COLV, previamente ao transplante, preveniu esta complicação (Yasufuku, 2001; Yasufuku, 2002).

A imunização de coelhos saudáveis com COLV reproduz uma doença com todas as características da ES, tais como fibrose nos órgãos normalmente afetados pela doença (Bezerra, 2006; Ogido, 2008; Teodoro, 2002; Yoshinari, 2005), vasculopatia, caracterizada por apoptose e ativação de células endoteliais presentes nas artérias intrapulmonares, assim como diminuição da complascência da artéria pulmonar (Marangoni, 2010a; Marangoni 2010b; Marangoni, 2011) e autoimunidade com produção de anticorpos anti-SCI 70 e anti COLV, detectados a partir do $30^{\circ}$ dia após a imunização (Callado, 2005; Callado, 2007). É importante ressaltar que a imunização com outros tipos de colágeno, assim como com albumina, não desencadeia quadro semelhante (Teodoro, 2002; Callado, 2007). 
Chama atenção a deposição aumentada de colágeno na derme dos animais imunizados com COLV (COL-IM) já no $7^{\circ}$ dia após a imunização (de Oliveira, 2009). Neste período, ainda não se observam linfócitos no tecido dérmico e não são detectados autoanticorpos (Bezerra, 2007; Callado 2007), o que sugere que o remodelamento seja consequente à apoptose ou à ativação das células endoteliais.

Outra importante observação é que tanto na derme como nos pulmões de pacientes com ES e de animais COLV-IM, ocorre depósito aumentado de COLV atípico, distribuído no tecido sob a forma de fibras espessas e distorcidas, diferente das fibras finas observadas na pele de indivíduos saudáveis e coelhos controle (Bezerra, 2007; Teodoro, 2002; Parra 2009). Notadamente, foi observada correlação negativa entre a expressão de COLV no pulmão de pacientes com ES e a capacidade vital, a capacidade vital forçada, o volume expiratório forçado e a difusão de monóxido de carbono (Parra, 2009), mas a relevância clínica da deposição de COLV na derme de pacientes com ES ainda não foi avaliada.

Dessa forma, importantes questões são levantadas. Em primeiro lugar, o depósito de COLV na pele poderia refletir o espessamento cutâneo e o grau de atividade da doença? Haveria diferença no depósito desta proteína entre as diferentes fases da ES? O COLV poderia estar ligado à vasculopatia, induzindo ativação e apoptose das células endoteliais? 
2 OBJETIVOS 
Tendo em vista as observações acima, os objetivos deste estudo foram:

1.1. quantificar e avaliar o perfil morfológico do COLV, do COLI e do COLIII na derme e na cultura de fibroblastos de pacientes com ES e de controles saudáveis;

1.2. pesquisar a relevância clínica do depósito de COLV na derme de pacientes com ES, buscando-se correlação com o tempo de evolução, o espessamento cutâneo e a atividade da doença;

1.3. quantificar a expressão de marcadores de apoptose (caspase-3) e de ativação endotelial (ET1, CTFG, TGFß e VEGF) nas células endoteliais dérmicas de pacientes com ES e de controles saudáveis e pesquisar sua correlação com o depósito de COLV;

1.4. quantificar a expressão de COLV, caspase-3, ET1, CTGF, TGF $\beta$ e VEGF na derme de coelhos COL-IM, comparando-se com controles. 


\section{PACIENTES E MÉTODOS}




\subsection{Pacientes}

Este estudo foi aprovado pelo comitê de ética local (CAPPESQ = 0817/07) e, de acordo com a declaração de Helsinque, todos os participantes deram seu consentimento após informações detalhadas sobre o estudo e os potencias riscos.

Foram obtidas biópsias de pele da superfície dorsal do antebraço distal de 18 pacientes, segundo os critérios do Colégio Americano de Reumatologia (Subcommittee for Scleroderma Criteria of the American Rheumatism Association Diagnostic and Therapeutic Criteria Committee, 1980). Sete indivíduos eram virgens de tratamento e 11 estavam há pelo menos 3 meses sem uso de medicamentos imunossupressores ou antifibróticos. Os indivíduos apresentando dois anos ou menos a partir do primeiro sintoma não-Raynaud foram considerados portadores de doença precoce e os demais, portadores de doença tardia (White, 1995). A avaliação do espessamento da pele foi realizada por meio do escore de Rodnan modificado (MRSS), que consiste na palpação de 17 áreas do corpo, incluindo face, tórax anterior, abdome, braços, antebraços, mãos, dedos das mãos, coxas, pernas e pés. O grau de espessamento cutâneo é medido por uma escala de 0 (normal) a 3 (grave) e o escore final resulta da soma dos pontos de cada área examinada, variando de 0 a 51 (Clements, 1995). Já a atividade da doença foi calculada pelo índice de 
atividade de Valentini (Valentini, 2001; Valentini, 2003), que se refere à avaliação de 10 parâmetros, conforme a tabela 2, sendo que a doença é considerada ativa quando a soma destes itens é superior a 3 (Valentini, 2001).

Em 6 destes pacientes, os dados foram coletados prospectivamente, enquanto em 12 pacientes, os dados foram coletados retrospectivamente a partir da revisão de seus prontuários.

Tabela 2 - Índice de atividade de Valentini

\begin{tabular}{lc}
\hline Parâmetros & Escore \\
\hline MRSS >14 & 1,0 \\
Escleredema & 0,5 \\
Piora da pele * $^{*}$ & 2,0 \\
Necrose digital & 0,5 \\
Piora vascular * & 0,5 \\
Artrite & 0,5 \\
DLCO < 80\% do previsto** & 0,5 \\
Piora da dispneia * & 2,0 \\
Velocidade de hemossedimentação & 1,5 \\
$>30$ mm na primeira hora & \\
Hipocomplementenemia & 1,0 \\
Índice máximo de atividade & 10
\end{tabular}

* deteriorização em relação ao último mês, avaliada pelo paciente ** Capacidade de Difusão do Dióxido de Carbono

Como controles, foram obtidas biópsias de pele de 10 indivíduos saudáveis, pareados por idade e sexo. As bióspias de pele foram fixadas em solução de formol a 10\%, embebidas em parafina, e seções de 3 a $4 \mu \mathrm{m}$ foram 
coradas por Hematoxilina e Eosina (H\&E) e montadas em lâminas com 3aminopropiltriethoxi silane (Sigma Chemical Co., St. Louis, MO, USA) para análises adicionais.

Dois patologistas que desconheciam os achados clínicos revisaram as biópsias de pele. O diagnóstico histológico de ES foi confirmado quando pelo menos um dos seguintes critérios foi observado em lâminas coradas por H\&E (Cotton, 1999):

1: aparência normal da matriz extracelular na derme, mas presença de edema perivascular (Ed) ou infiltrado inflamatório mononuclear (setas) (figura $5 A)$;

2: fibrose leve, caracterizada pela presença de colágeno nos anexos (setas) e/ou tecido adiposo subcutâneo, associada ou não a perda de definição entre a camada papilar e reticular e a atrofia da epiderme (figura 5B);

3: fibrose densa e uniforme da derme com perda dos anexos, associada a atrofia de epiderme (figura 5C).

As lâminas dos controles evidenciaram ausência de doença cutânea (figura 5D) 


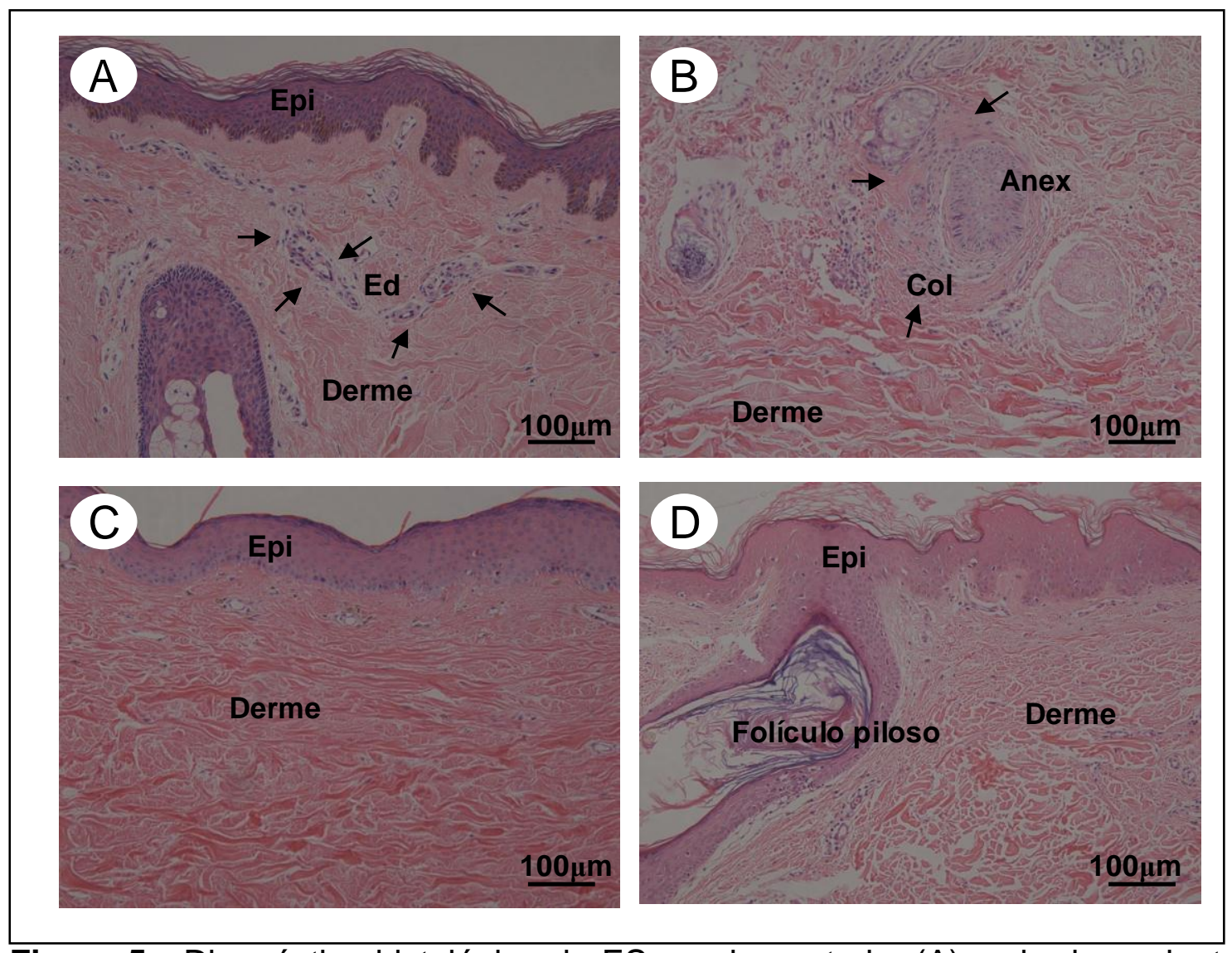

Figura 5 - Diagnóstico histológico da ES e pele controle. (A): pele de paciente com ES com aparência normal da derme, apresentando edema perivascular (Ed), observado como uma região rosa-clara ao redor dos vasos e infiltrado perivascular mononuclear (seta). (B): pele de paciente com fibrose leve apresentando encarceramento dos anexos cutâneos (Anex) por fibras de colágeno (Col, setas). A epiderme estaria no campo superior. (C): Pele de paciente com ES com fibrose densa caracterizada por fibrose uniforme com perda dos anexos e atrofia da epiderme. (D): aparência normal da pele controle. Coloração em H\&E, aumento de 200X. Epi: epiderme 


\subsection{Modelo experimental de ES por imunização com colágeno V}

Para este estudo, foram utilizadas amostras de pele de coelhos provenientes de estudos prévios realizados no Laboratório de Matriz Extracelular, Disciplina de Reumatologia da FMUSP, que avaliaram animais imunizados com COLV emulsificado com adjuvante de Freund (COLV-IM) e controles imunizados com adjuvante de Freund. A utilização dos animais nestes protocolos experimentais estava de acordo com os Princípios Éticos na Experimentação Animal, adotados pela Sociedade Brasileira de Ciência em Animais de Laboratório (SBCAL/COBEA) e foram aprovados pelo comitê de ética local.

Coelhas da linhagem Nova Zelândia foram imunizadas com COLV por via subcutânea, injetando-se $1 \mathrm{mg}$ de COLV, isolado de placenta humana, extraído por precipitação com cloreto de sódio (Miller, 1982), diluído em $1 \mathrm{ml}$ de ácido acético $10 \mathrm{mM}$ e emulsificado em igual volume de adjuvante completo de Freund (Sigma Chemical Co.). Quatro semanas após, as coelhas receberam uma dose idêntica de COLV com adjuvante completo de Freund e, posteriormente, dois reforços de $1 \mathrm{mg}$ de COLV mais $1 \mathrm{ml}$ adjuvante incompleto de Freund, pela via intramuscular, separados por um intervalo de 15 dias (quadro 1). O grupo controle foi inoculado com adjuvante de Freund completo nas duas primeiras imunizações e, depois, com adjuvante de Freund incompleto 
diluído em ácido acético $10 \mathrm{mM}$, seguindo o mesmo protocolo utilizado para a imunização de coelhos com COLV. Animais de ambos os grupos apresentavam a mesma idade, com peso aproximado de $2500 \mathrm{~g}$ (quadro 1).

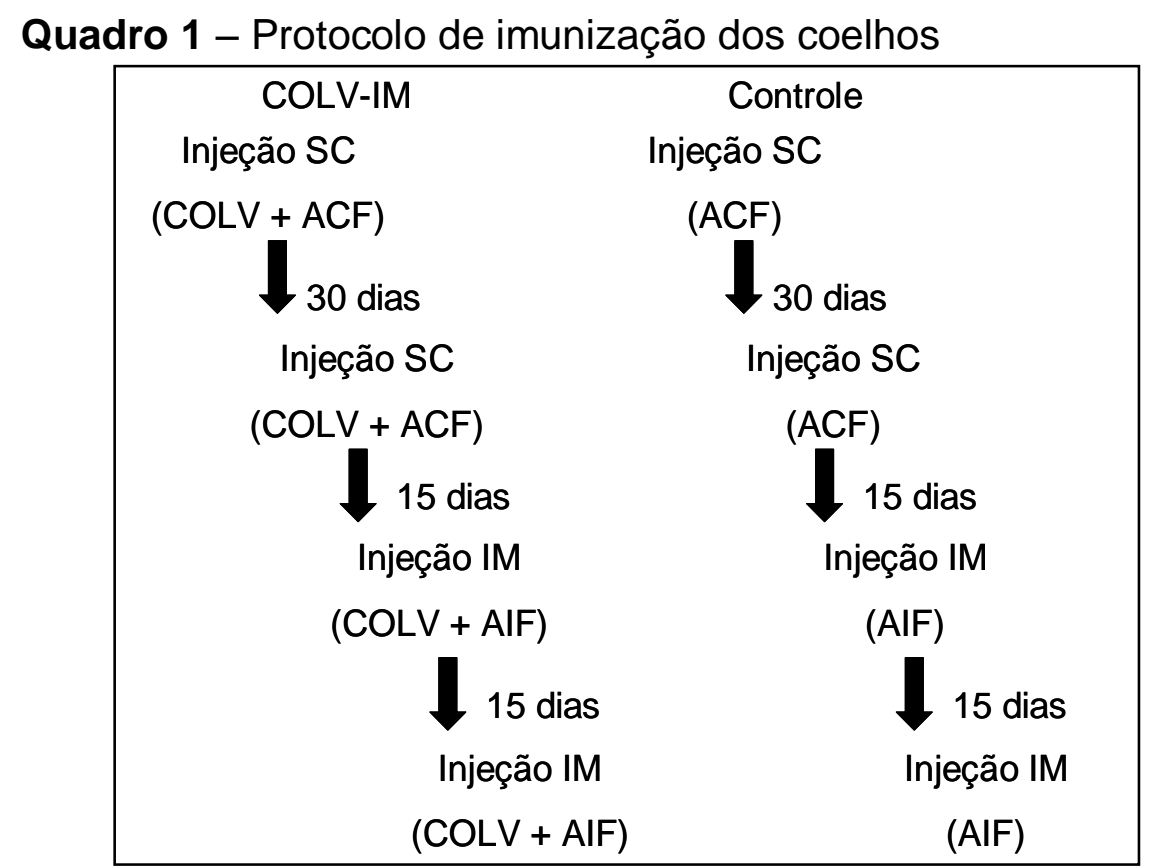

ACF: adjuvante completo de Freund; AIF: adjuvante incompleto de Freund; SC: subcutâneo; IM: intramuscular.

Após anestesia, foi realizada biópsia de pele da região dorsal, nos tempos 7, 30, 75 e 210 dias após a primeira imunização com COLV mais adjuvante de Freund ou adjuvante de Freund apenas. Os espécimes coletados foram imersos em formol a $10 \%$ por 24 horas, embebidos em parafina, cortados numa espessura de 3-4 $\mu \mathrm{m}$, montados em lâminas com 3-aminopropyltriethoxy silane (Sigma Chemical Co., St. Louis, MO, USA) e corados em H\&E e tricômio de Masson para posterior análise. 


\subsection{Imunofluorêcencia para os colágenos I, III e V na derme humana e do colágeno V na derme de coelhos}

Para realizar a imunomarcação do COLI, COLIII e COLV na derme, as lâminas silanizadas foram desidratas em xilol e reidratadas em concentrações decrescentes de etanol. A recuperação antigênica foi realizada por meio de tratamento enzimático com pepsina bovina (10000 unidades/ml) (Sigma Chemical Co.) em ácido acético $0,5 \mathrm{M}$, por $30 \mathrm{~min}$, a $37^{\circ} \mathrm{C}$. Para a imunodetecção do COLIII na derme dos pacientes e do COLV na derme dos coelhos, os sítios inespecíficos foram bloqueados com $\mathrm{H}_{2} \mathrm{O}_{2} 3 \%$, durante 25 min, e, subsequentemente, com avidina e biotina (Vector Laboratories, Inc, Burlngame, CA, USA), durante 10 min cada, seguido por bloqueio com leite em pó desnatado a $5 \%$, diluído em tampão fosfato salino (PBS), durante $30 \mathrm{~min}$, em temperatura ambiente. Para imunodetecção do COLI e do COLV na pele dos pacientes, utilizou-se bloqueio apenas com leite desnatado a 5\% em PBS. Finalmente, os fragmentos de derme humana foram incubados durante a noite, a $4^{\circ} \mathrm{C}$, com anticorpo de policlonal anti-COLV humano (1:50) ou anticorpo policlonal anti-COLIII (1:200) ou anticorpo policlonal anti-COLI (1:150), todos obtidos em coelho (Spiess, 2007). De maneira semelhante, o tecido dérmico dos coelhos foi incubado com anticorpo policlonal anti-COLV humano obtido em camundongos (1:150) (Spiess, 2007). Após a incubação, os cortes foram 
lavados com PBS com Tween $_{20} 0,05 \%$ e incubados durante 90 min, a temperatura ambiente, com os anticorpos de cabra anti lgG de coelho ou de camundongo, conjugados com fluoresceína (Sigma Chemical Co.), diluídos 1:50 em solução de azul de Evans a 0,006\% em PBS. Finalmente, as lâminas foram montadas com glicerol tamponado. Para controles negativos, as lâminas foram incubadas com PBS.

\subsection{Histomorfometria dos colágenos I, III e V na derme humana e do colágeno $\mathrm{V}$ na derme de coelhos}

A histomorfometria foi realizada para quantificar a densidade de fibras imunomarcadas de COLI, COLIII e COLV, por meio de análise de imagem. Resumidamente, este sistema é constituído por uma câmera fotográfica (Olympus Co, St Laurent, Quebec, Canada) acoplada a um microscópio (Olympus BX51, Olympus Co, Tokyo, Japan), que captura as imagens e as envia para o monitor, por um sistema de digitalização (Oculus TCX, Coreco, Inc, St. Laurent, Quebec, Canada). As imagens são então processadas por um software (Image Pro-Plus 6.0) que permite quantificar as fibras imunomarcadas em verde.

A densidade das fibras de colágeno foi medida em todos os campos microscópicos, englobando uma área delimitada pela membrana basal, com 
profundidade superior a $70 \mu \mathrm{m}$ (Sorrel, 2004), o que permitiu avaliar a derme papilar e reticular, quando o limite entre estas camadas não era visualizado devido à fibrose (figura 6). A derme foi estudada em magnificação de 200X.

A densidade de colágeno foi expressa como a quantidade de fibras medidas divida pela área total observada e multiplicada por 100 . O resultado final de cada lâmina foi dado como a média dos campos avaliados (Parra, 2009).

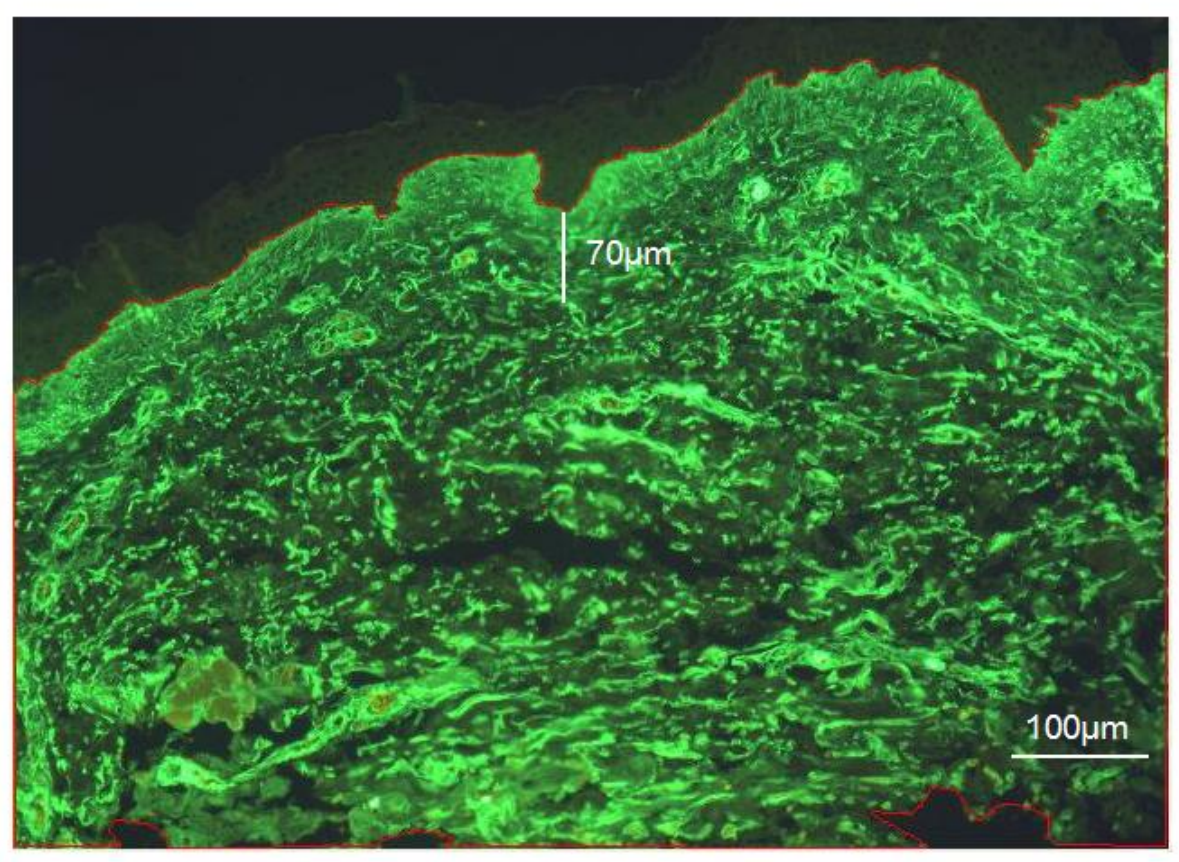

Figura 6 - Diagrama esquemático da área medida. A área marcada em vermelho, delimitada pela membrana basal, apresenta profundidade superior a $70 \mu \mathrm{m}$ para assegurar que tanto a derme papilar quanto a derme reticular sejam medidas, já que o limite entre estas camadas se perde devido à fibrose. 


\subsection{Quantificação de caspase-3, ET1, CTGF, TGF $\beta$ e VEGF nas células endoteliais de pacientes com ES e de controles e de coelhos COLV-IM e de controles}

\subsubsection{Identificação das células endoteliais em apoptose}

Para identificar células em apoptose, utilizou-se a imunomarcação para caspase-3, caspase efetora associada à destruição da célula e à formação dos corpos apoptóticos (Porter, 1999). Tanto fibroblastos quanto células endoteliais foram marcados, mas uma vez que o foco de presente estudo foi a avaliação das células endoteliais, apenas estas foram quantificadas, reconhecidas por meio de marcação acastanhada na parede interna das arteríolas (figura 7, setas). 


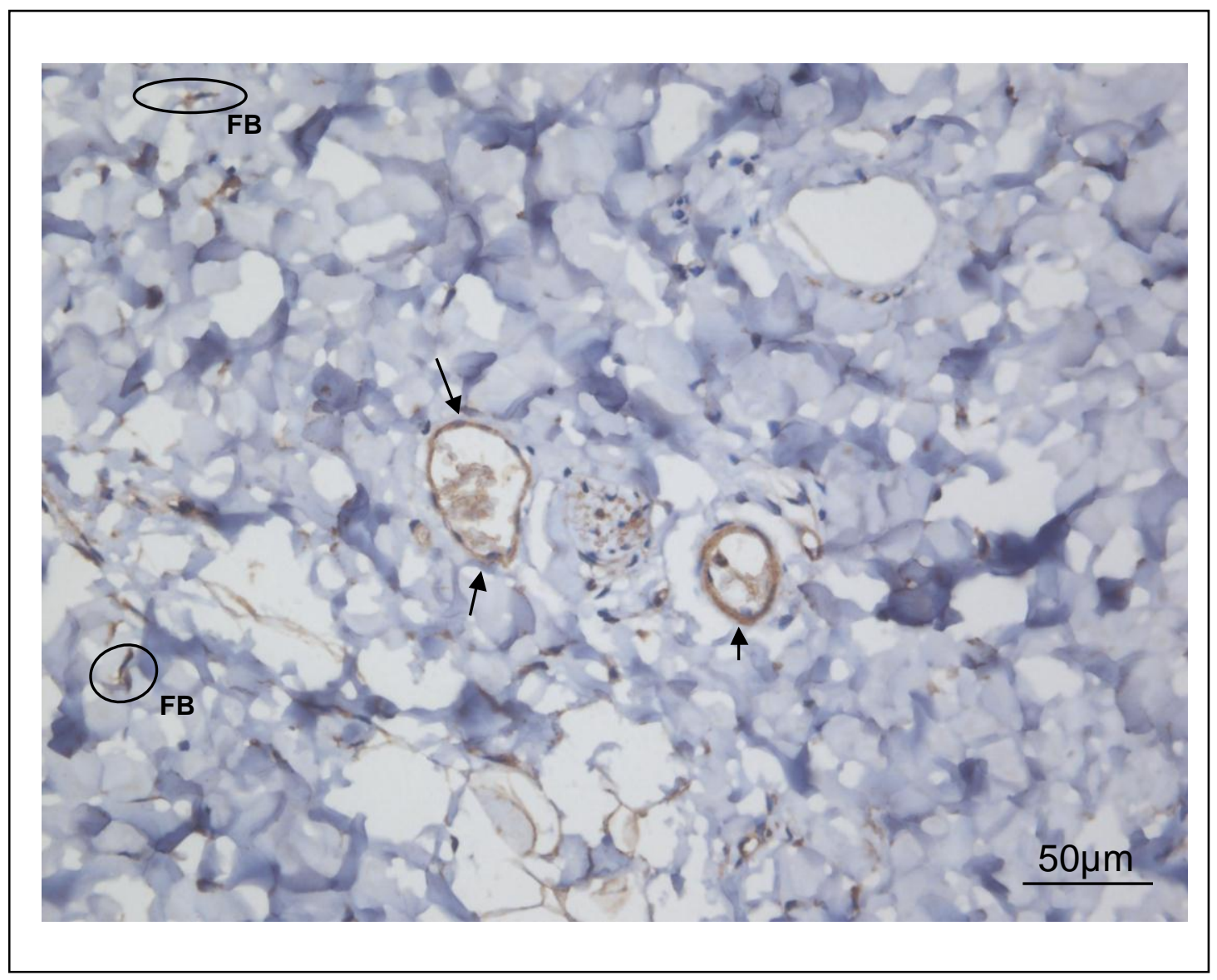

Figura 7 - identificação das células endoteliais em apoptose, por meio da imunomarcação com caspase-3. As células endoteliais imunomarcadas presentes na parede das arteríolas aparecem com coloração acastanhanda (setas). Alguns fibroblastos (FB), reconhecidos pelos seus núcleos alongados, também foram marcados, entretanto não foram quantificados. Aumento de 400x. 


\subsubsection{Imunohistoquímica para detecção de caspase-3, ET1, VCAM, CTGF,} TGF $\beta$ e VEGF nas células endoteliais

As reações de imuno-histoquímica para a detecção de caspase-3, ET1, CTGF, TGF $\beta$ e VEGF nas células endoteliais foram padronizadas de acordo com a tabela 3 . 
Tabela 3 - Padronização da imuno-histoquímica para detecção de caspase-3, ET1, TGF $\beta$, CTGF e VEGF

\begin{tabular}{|c|c|c|c|c|c|}
\hline Marcador & Tecido & Digestão & $\begin{array}{l}\text { Bloqueio Sítios } \\
\text { Inespecíficos }\end{array}$ & $\begin{array}{l}\text { Anticorpo } \\
\text { Primário }\end{array}$ & $\begin{array}{l}\text { Anticorpo } \\
\text { Secundário }\end{array}$ \\
\hline Caspase-3 & $\begin{array}{l}\text { Pele Humana } \\
\text { e de Coelhos }\end{array}$ & $\begin{array}{l}\text { Panela a vapor } \\
20 \text { min a } 37^{\circ} \mathrm{C}\end{array}$ & $\begin{array}{c}\text { Água oxigenada } \\
30 \text { volumes } \\
\text { (7 lavagens } 5 \\
\text { min) }\end{array}$ & $\begin{array}{c}\text { Anti VEGF } \\
\text { policlonal obtido } \\
\text { em cabra 1: } 450 \\
\text { (Cód.: sc 1221, } \\
\text { Santa Cruz } \\
\text { Biotechnology } \\
\text { Inc) }\end{array}$ & $\begin{array}{l}\text { Kit NovoLink } \\
\text { Polymer } \\
\text { Detection } \\
\text { System, } \\
\text { Newcastle, } \\
\text { Reino Unido }\end{array}$ \\
\hline ET1 & Pele Humana & $\begin{array}{l}\text { Citrato em } \\
\text { panela de } \\
\text { pressão } \\
125^{\circ} \mathrm{C}, 1 \mathrm{~min}\end{array}$ & $\begin{array}{c}\text { Água oxigenada } \\
30 \text { volumes } \\
\text { (7 lavagens de } \\
5 \text { min })\end{array}$ & $\begin{array}{c}\text { Anti ET-1 } \\
\text { policlonal obtido } \\
\text { em cabra; } 1: 500 \\
\text { (cód.: sc } 21625 \text {, } \\
\text { Santa Cruz } \\
\text { Biotechnology } \\
\text { Inc, Santa Cruz, } \\
\text { CA- EUA) }\end{array}$ & $\begin{array}{c}\text { ABCKit } \\
\text { Vectastain } \\
\text { (Vector Elite } \\
\text { PK-anti-cabra- } \\
\text { Burlingame, } \\
\text { CA, EUA) }\end{array}$ \\
\hline ET1 & Pele Coelho & $\begin{array}{l}\text { Tripsina } 0,25 \% \\
20 \text { min em } \\
\text { estufa } 37^{\circ} \mathrm{C}\end{array}$ & $\begin{array}{c}\text { Agua oxigenada } \\
30 \text { volumes } \\
\text { (7 lavagens de } \\
5 \text { min) + leite } \\
\text { desnatado } 5 \% \\
\text { (30 min) }\end{array}$ & $\begin{array}{c}\text { Anti ET-1 } \\
\text { policonal obtido } \\
\text { em cabra; } 1: 150 \\
\text { (cód.: sc } 21625 \text {, } \\
\text { Santa Cruz } \\
\text { Biotechnology } \\
\text { Inc) }\end{array}$ & $\begin{array}{c}\text { ABCKit } \\
\text { Vectastain } \\
\text { (Vector Elite } \\
\text { PK- anti-cabra- } \\
\text { Burlingame, } \\
\text { CA, EUA) }\end{array}$ \\
\hline CTGF & $\begin{array}{l}\text { Pele Humana } \\
\text { e de Coelhos }\end{array}$ & $\begin{array}{c}\text { Tripsina } 0,25 \% \\
20 \text { min em } \\
\text { estufa } 37^{\circ} \mathrm{C}\end{array}$ & $\begin{array}{c}\text { Metanol } 1 / 2 \text { a } 1 / 2 \\
\text { com água } \\
\text { oxigenada ( } 10 \\
\text { min) seguido de } \\
\text { azida } 1 \% \text { em } \\
\text { água oxigenada } \\
10 \text { min }\end{array}$ & $\begin{array}{c}\text { Anti CTGF } \\
\text { policlonal obtido } \\
\text { em cabra 1: } 100 \\
\text { (Cód.: sc } 34772 \text {, } \\
\text { Santa Cruz } \\
\text { Biotechnology } \\
\text { Inc) }\end{array}$ & $\begin{array}{c}\text { ABCKit } \\
\text { Vectastain } \\
\text { (Vector Elite } \\
\text { PK- anti-cabra- } \\
\text { Burlingame, } \\
\text { CA, EUA) }\end{array}$ \\
\hline TGF $\beta$ & $\begin{array}{l}\text { Pele Humana } \\
\text { e de Coelhos }\end{array}$ & $\begin{array}{l}\text { Panela a vapor } \\
20 \text { min a } 37^{\circ} \mathrm{C}\end{array}$ & $\begin{array}{c}\text { Água oxigenada } \\
30 \text { volumes } \\
\text { (7 lavagens } 5 \\
\text { min) }\end{array}$ & $\begin{array}{c}\text { Anti TGF } \\
\text { policlonal obtido } \\
\text { em cabra 1: } 100 \\
\text { (Cód.: sc 31608, } \\
\text { Santa Cruz } \\
\text { Biotechnology } \\
\text { Inc) }\end{array}$ & $\begin{array}{c}\text { ABCKit } \\
\text { Vectastain } \\
\text { (Vector Elite } \\
\text { PK- anti-cabra- } \\
\text { Burlingame, } \\
\text { CA, EUA) }\end{array}$ \\
\hline VEGF & $\begin{array}{l}\text { Pele Humana } \\
\text { e de Coelhos }\end{array}$ & $\begin{array}{c}\text { Tripsina } 0,25 \% \\
20 \text { min em } \\
\text { estufa } 37^{\circ} \mathrm{C}\end{array}$ & $\begin{array}{c}\text { Agua oxigenada } \\
30 \text { volumes } \\
\text { (7 lavagens de } \\
5 \text { min })\end{array}$ & $\begin{array}{c}\text { Anti VEGF } \\
\text { policlonal obtido } \\
\text { em cabra 1: } 250 \\
\text { (Cód.: sc } 1881, \\
\text { Santa Cruz } \\
\text { Biotechnology } \\
\text { Inc) }\end{array}$ & $\begin{array}{c}\text { ABCKit } \\
\text { Vectastain } \\
\text { (Vector Elite } \\
\text { PK- anti-cabra- } \\
\text { Burlingame, } \\
\text { CA, EUA) }\end{array}$ \\
\hline
\end{tabular}




\subsubsection{Histomorfometria de caspase-3, ET1, CTGF, TGF $\beta$ e VEGF nas células endoteliais}

Para análise quantitativa da expressão de caspase-3, ET1, TGF $\beta$, CTGF e VEGF foi utilizado o método esterológico de contagem de pontos, por meio de um retículo formado por 100 pontos e 50 linhas, cada uma medindo 25 $\mu \mathrm{m}$ de comprimento, adaptado a microscópio convencional (Weibel, 1990). Foram quantificadas todas as células (marcadas e não marcadas) que incidiam sobre os pontos, avaliando-se 10 campos em aumento de 400x. Posteriormente, foi calculada a porcentagem de células marcadas em cada campo e o resultado final foi considerado a média destes campos. 


\subsection{Estudo da cultura de fibroblastos dérmicos provenientes de pacientes e controles}

\subsubsection{Cultura primária de fibroblastos dérmicos por explant}

Para a cultura de fibroblastos, foram utilizados fragmentos dérmicos de 6 pacientes e de 6 controles. A cultura primária foi obtida pelo método de explant (Coelho, 2000) imediatamente após a biópsia de pele. Os espécimes foram seccionados em pequenos fragmentos e transferidos para uma garrafa de 25 $\mathrm{cm}^{2}$ (Costar, EUA) contendo Meio de Dulbeco modificado por Eagle (DMEM), suplementado com soro fetal bovino a $20 \%$, L-glutamina a $1 \%$, penicilia e streptomicina a $1 \%$. Os fragmentos foram incubados a $37^{\circ} \mathrm{C}$, em atmosfera de $\mathrm{CO}_{2}$ a $5 \%$, até atingirem confluência. Uma vez confluentes, os fibroblastos dérmicos foram tratados com tripsina a $0,2 \%$ e transferidos para garrafas de 75 $\mathrm{cm}^{2}$ para extração de RNA e, posteriormente, para lamínulas colocadas em placas de 24 poços para imunomarcação. Foram utilizadas células entre a terceira e a quinta passagens (Pannu, 2006). 


\subsubsection{Imunomarcação dos colágenos I, III e V na derme humana e do colágeno $\mathrm{V}$ na derme de coelhos na cultura de fibroblastos}

Após atingirem confluência nas lamínulas, os fibroblastos foram fixados com paraformoldeído a $4 \%$, por 1 hora, a $4^{\circ} \mathrm{C}$. A dupla marcação foi realizada pela incubação a $4^{\circ} \mathrm{C}$, durante a noite, com os anticorpos policlonais anti COLI ou COLIII humano, obtidos em coelho, e anticorpo policlonal anti COLV humano, obtido em camundongo, todos na diluição de 1:20 em PBS (Spiess, 2007). Após este período, os cortes foram lavados com PBS com Tween 20 $0,05 \%$ e incubados durante $60 \mathrm{~min}$, em temperatura ambiente, com os anticorpos de cabra anti IgG de camundongo Alexa 633 (Invitrogen, Eugene, OR, USA) e anti lgG de coelho Alexa 546 (Invitrogen), na diluição de 1:200 em PBS. Os núcleos foram contracorados com $1 \mu \mathrm{g} / \mathrm{ml}$ bisbenzimida Hoechst 33258 (Invitrogen). As células isoladas foram identificadas como fibroblastos por meio de sua morfologia típica, observada em microscopia, e pela sua caracterização, utilizando-se anticorpos antivimentina (1:800; Dako, Denmark) $(G a o, 2010)$ (figura 8). Finalmente, a reação foi verificada em microscópio confocal (Zeiss LSM 510 META /UV, Germany) para a reconstrução tridimensional das fibras de colágeno. 


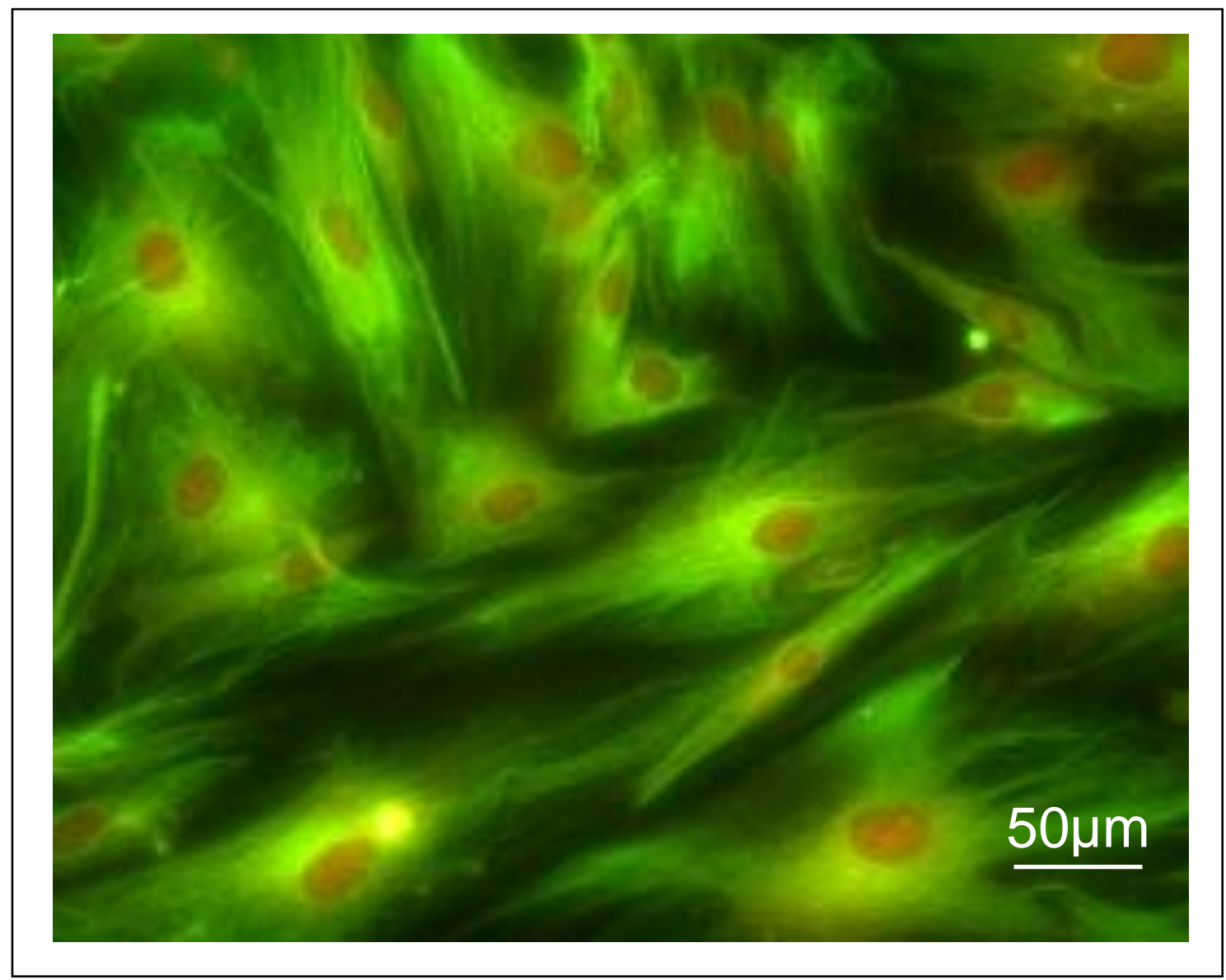

Figura 8 - Identificação dos fibroblastos na cultura celular. As células cultivadas a partir da derme de pacientes com ES e de controles foram identificadas como fibroblastos devido à sua morfologia característica e pela imunomarcação positiva para vimentina, proteína do citoesqueleto dos fibroblastos, coradas em verde claro em seu citoplasma. 


\subsubsection{Extração de mRNA, transcrição reversa e PCR em tempo real}

Após os fibroblastos atingirem confluência nas garrafas de $75 \mathrm{~cm}^{2}, 0$ RNA total foi isolado utilizando-se Trizol total (Invitrogen Corporation, Carlsbad, CA, USA), de acordo com as instruções do fabricante. Resumidamente, o RNA total $(4.0 \mu \mathrm{g})$ proveniente dos fibroblastos dérmicos foi transcrito em DNA complementar (cDNA), usando-se oligo $\mathrm{dT}_{12-18}$ primer (GE Healthcare Life Sciences, Little Chalfont, St Giles, UK) e Superscript III (Invitrogen Corporation, Carlbad, CA, USA). Todas as amostras foram testadas em duplicata e as condições de ciclagem foram as seguintes: 40 ciclos, cinco minutos a $95^{\circ} \mathrm{C}$ (aquecimento inicial), 60 segundos a 95ำ (desnaturação), 60 segundos a $60^{\circ} \mathrm{C}$ (anelamento) e 60 segundos a $72^{\circ} \mathrm{C}$ (extensão). O mRNA dos genes foi amplificado utilizando-se primers específicos (Invitrogen Corporation) na concentração final de $250 \mathrm{nmol} /$. Os oligonucleotídeos foram desenhados baseando-se na região codificadora próxima à terminação 3' do gene por meio do Primer 3 (http:// frodo.wi.mit.edu/cgi-bin/primer3/primer3_www.cgi), segundo a tabela 4. 
Tabela 4- oligonucleotídeos

\begin{tabular}{lll}
\hline Gene & Esquerda $\left(5^{\prime} \rightarrow 3^{\prime}\right)$ & Direita $\left(5^{\prime} \rightarrow 3^{\prime}\right)$ \\
\hline COLl $\alpha_{1}$ & AACAGCCGCTTCACCTACAG & TGGGATGGAGGGAGTTTACA \\
COLIII $\alpha_{1}$ & GATGGGGTCAAATGAAGGTG & TGATCAGGACCACCAATGTC \\
COLV $\alpha_{1}$ & GTGGCACAGAATTGCTCTCA & GTGGCACAGAATTGCTCTCA \\
COLV $\alpha_{2}$ & GGAAATGTGGGCAAGACTGT & TTGATGGTGGTGCTCATTGT \\
ACTB & AGAAAATCTGGCACCACACC & AGAGGCGTACAGGGATAGCA \\
\hline
\end{tabular}

As amostras foram analisadas pelo software Rotor-Gene 6 System (Corbett Research, Mortlake, Australia). A quantificação relativa dos genes de interesse foi normatizada de acordo com a expressão de ACTB e a expressão gênica de cada amostra foi comparada com o pool de células. Utilizou-se o método comparativo CT e a expressão relativa foi calculada como $2^{-\mathrm{CT}}$ (Livak, 2001).

\subsubsection{Extração de colágeno, eletroforese em gel de poliacrilamida e immunoblot}

O colágeno foi isolado do sobrenadante de cultura de fibroblastos dérmicos. $\mathrm{O}$ eluato foi centrifugado a $3000 \mathrm{~g}$, durante 15 minutos, a $4^{\circ} \mathrm{C}$, para separação das células, e, a seguir, acrescentou-se $\mathrm{NaCl}$ a 4,5M, sob agitação, a $4^{\circ} \mathrm{C}$, para a precipitação do colágeno. Logo após, o colágeno foi isolado por meio de centrifugação a $27000 \mathrm{~g}$, durante 60 minutos, a $4^{\circ} \mathrm{C}$. Uma vez isolado, o 
colágeno foi diluído em ácido acético a $0,01 \mathrm{M}$, submetido à diálise com água destilada e liofilizada, a $-50^{\circ} \mathrm{C}$. Finalmente, para a identificação das cadeias do colágeno, foi realizada a corrida eletroforética em gel de poliacrilamida a 7,5\%, conforme descrição de Laemmli, em 1970 (Laemmli,1970; Teodoro, 2003). Em cada "poço" do gel de poliacrilamida acrescentou-se $30 \mu \mathrm{g}$ das frações de colágeno isolado, previamente diluído em ácido acético $0,01 \mathrm{~N}$, tratado com tampão de amostra (SDS 10\%, glicerina 10\%, azul de bromofenol $20 \%$ e 2mercaptoetanol) e fervido a $100^{\circ} \mathrm{C}$, por 3 minutos. Procedeu-se a eletroforese em tampão de corrida tris glicina $0,19 \mathrm{M}$ em pH 8,5 e SDS $0,1 \%$, a $4^{\circ} \mathrm{C}$, sob corrente elétrica constante de 80 volts, por duas horas.

Após a eletroforese, as cadeias de colágeno foram eletrotransferidas para uma membrana de nitrocelulose (Sigma Chemical Co.) em tampão tris $25 \mathrm{mM}$, glicina $192 \mathrm{mM}$ e metanol 10\%, por uma hora, a 100 volts. A eficiência da transferência foi confirmada pela coloração com solução de Ponceau S (Sigma Chem Co) $0,5 \%$.

Para o immunoblot, os sítios inespecíficos na membrana de nitrocelulose foram bloqueados com leite desnatado a 5\%, diluído em PBS. Após lavagem com PBS, o anticorpo policlonal anti-COLV, obtido em coelho, diluído 1:100 em BSA $1 \%$ em PBS com Tween $_{20}$ 0,05\%, foi incubado durante 1 hora, em temperatura ambiente. A membrana foi então lavada com PBS-Tween $20,05 \%$ e incubada com anticorpo de cabra anti IgG de coelho, conjugado com fosfatase alcalina (Sigma Chemical Co.), diluído 1:1000 em BSA 1\% em PBS 
com Tween $_{20}$ 0,05\%. A reação foi revelada com Nitrotetrazolium Blue Chloride (Sigma Chemical Co) e 5-Bromo-4-cloro-3-indolil fosfato p-toluidina (Sigma Chemical Co).

\subsection{Análise estatística}

Os resultados foram apresentados como mediana e intervalo, abrangendo o valor mínimo e o valor máximo observados. Quando a variável apresentava indicações de distribuição normal, segundo o teste de KolmogorovSmirnov, utilizou-se o teste $t$-student para comparação entre as médias de duas varíaveis contínuas e o ANOVA para comparação de $k$ variáveis contínuas. Quando a normalidade foi rejeitada, utilizou-se o teste de Mann Whitney para duas variáveis contínuas e o de Kruskal-Wallis para $k$ variáveis contínuas, quando as amostras eram independentes, e ANOVA não paramétrica, quando as variáveis eram relacionadas (Brunner, 2000). As variáveis categóricas foram comparadas pelo teste exato de Fisher.

Correlações entre a expressão de COLV na derme, MRSS, duração e atividade de doença e marcadores vasculares foram verificadas por meio do coeficiente de Pearson quando havia concordância com a distribuição normal e, em caso contrário, pelo coeficiente de Spearman. 
Para verificar se MRSS, índice de atividade de Valentini e tempo de duração da ES estavam independentemente associados com a expressão de COLV foi realizada regressão linear generalizada. O nível de significância foi considerado $>5 \%$. 
4 RESULTADOS 


\subsection{Caracterização dos pacientes e dos controles}

As principais características clínicas e laboratoriais dos pacientes e dos indivíduos-controle saudáveis, chamados doravante somente de controles, avaliadas neste estudo podem ser observadas na tabela 5. Não houve diferença significativa entre as características dos doadores das respectivas amostras de pele utilizadas para a análise histológica e para a cultura de fibroblastos. 
Tabela 5 - Características clínicas e laboratoriais dos pacientes cujas biópsias foram utilizadas para estudo histológico e para cultura de fibroblastos

\begin{tabular}{|c|c|c|c|}
\hline & Histologia & $\begin{array}{l}\text { Cultura de } \\
\text { Fibroblastos }\end{array}$ & $p^{1}$ \\
\hline $\mathrm{N}$ & 18 & 6 & \\
\hline Idade, mediana (variação) & $47,5$ (21 - 58 anos $)$ & 30 (21- 59 anos) & 0,53 \\
\hline Sexo feminino, N (\%) & $16(88,88)$ & $6(100)$ & 1 \\
\hline Forma difusa, $\mathrm{N}(\%)$ & $12(66,66)$ & $5(83,33)$ & 0,62 \\
\hline Forma limitada, $\mathrm{N}(\%)$ & $6(44,44)$ & $1(16,66)$ & 0,62 \\
\hline Doença Precoce ${ }^{2}, \mathrm{~N}(\%)$ & $6(33,33)$ & $4(66,66)$ & 0,19 \\
\hline Duração, mediana (variação) & $12(4-24$ meses $)$ & 12 (6 - 24 meses) & 0,38 \\
\hline Doença Tardia N (\%) & $12(77,77)$ & $2(33,33)$ & 0,19 \\
\hline Duração, mediana (variação) & 8,5 (5 - 29 anos) & $3,25$ (2,5 - 4 anos $)$ & 0,09 \\
\hline MRSS $^{3}$, mediana (variação) & $25(11-40)$ & $21(10-33)$ & 0,78 \\
\hline $\begin{array}{l}\text { Índice de Atividade de Valentini, } \\
\text { mediana (variação) }\end{array}$ & $3(0,5-5)$ & $3,5(1-4,5)$ & 0,89 \\
\hline Doença Ativa ${ }^{4}, \mathrm{~N}(\%)$ & $10(55,55)$ & $5(83,33)$ & 0,35 \\
\hline Doença Pulmonar Intersticial ${ }^{\mathrm{b}}, \mathrm{N}(\%)$ & $14(66,67)$ & $4(66,66)$ & 0,61 \\
\hline $\mathrm{FAN}+, \mathrm{N}(\%)$ & $18(100)$ & $6(100)$ & - \\
\hline anti-Scl70 +, N (\%) & $8(44,44)$ & $4(66,66)$ & 0,64 \\
\hline Anticentrômero +, N (\%) & $2(11,11)$ & $1(16,66)$ & 1 \\
\hline
\end{tabular}

1. os grupos foram comparados utilizando-se o teste de Mann-Whitney para variáveis contínuas e o teste exato de Fisher para variáveis categóricas.

2. doença precoce foi definida como 2 anos ou menos a partir do primeiro sintoma não-Raynaud (White, 1995)

3. escore de Rodnan Modificado

4. de acordo com o índice de atividade de Valentini (Valentini, 2003)

5. capacidade vital forçada $<70 \%$ do previsto ou opacidades em vidro fosco/fibrose observados na tomografia de tórax de alta resolução (Behr, 2008; Wells, 2008) 
Em relação ao diagnóstico histológico dos 18 pacientes, apenas 2 casos $(11,11 \%)$ apresentavam matriz extracelular normal, com a presença de edema perivascular e infiltrado inflamatório. Fibrose leve foi observada em 8 pacientes $(44,44 \%)$ e fibrose densa também em 8 pacientes $(44,44 \%)$.

\subsection{Expressão dos colágenos I, III e V na derme de pacientes com doença precoce, com doença tardia e controles}

Foi realizada a imunomarcação do tecido dérmico humano com o objetivo de avaliar a distribuição e o padrão morfológico dos colágenos dos tipos I, III e V, bem como de quantificá-los pela análise de imagem.

Nas amostras imunomarcadas de derme dos controles, foram observadas fibras finas de COLV distribuídas de forma linear e homogênea ao longo da membrana basal (figura 9A e 9B, setas), ao redor dos vasos (figura 9A e 9C, setas), e em forma de ondulações na derme, que mantém sua arquitetura normal (figura 9A). Entretanto, nas amostras imunomarcadas de pele de pacientes com ES precoce, foram visualizadas fibras grossas de COLV com distribuição em bandas ao longo da membrana basal (figura 9D e 9E, setas) e dos pequenos vasos (figura 9D e 9F, setas), formando agregados densos na derme (figura 9D). Finalmente, as amostras imunomarcadas de derme de pacientes com doença tardia apresentaram fibras espessadas de COLV, 
irregularmente distribuídas, em padrão nodular, envolvendo a membrana basal (figura 9G e 9H, setas), pequenos vasos (figura 9l, setas) e a derme (figura 9G).

A quantificação do COLV mostrou expressão aumentada desta proteína na derme dos pacientes com ES, tanto no estágio inicial quanto em fases tardias da doença, quando comparados à derme dos controles. Notadamente, pacientes com doença precoce apresentaram maior expressão de COLV, quando comparados àqueles com doença tardia (tabela 6). Além disso, observou-se correlação negativa entre a expressão de COLV e a duração da doença em meses (tabela 7). 


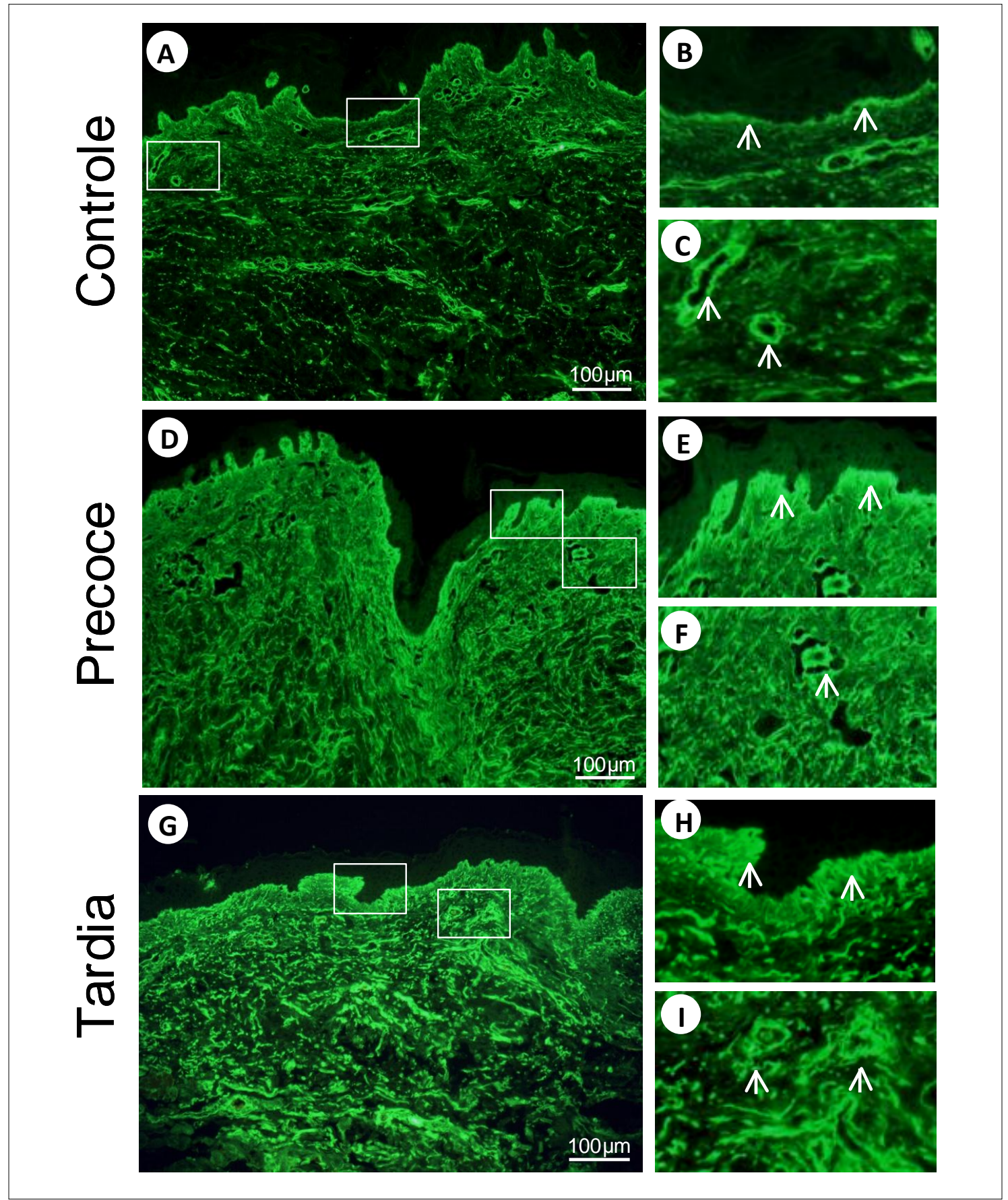

Figura 9 -Imunomarcação do COLV na derme de pacientes com ES e controles. A-C: Derme de controle saudável apresentando fibras finas de COLV corado em verde e distribuição sob a forma de ondulações na derme $(A)$ ao longo da membrana basal (B, setas) e ao redor dos vasos (C, setas). D-F: ES precoce apresentando fibras grossas de COLV, formando agregados densos e irregulares na derme (D), exibindo distribuição em banda ao longo da membrana basal ( $E$, setas) e presente ao redor dos pequenos vasos ( $F$, setas). G-I: $E S$ tardia com fibras espessadas de COLV de aspecto micronodular ao longo da membrana basal ( $\mathrm{H}$, setas), ao redor dos vasos (I, setas) e na derme (G). (aumento de 200X) 
Na pele dos controles, as fibras de COLI mostraram-se frouxamente distribuídas ao longo da membrana basal (figura 10A e 10B, setas), assumindo um padrão em cesto de vime nas camadas papilar e reticular (figura 10A), e depositadas discretamente na parede dos pequenos vasos (figura 10C, setas). $\mathrm{Na}$ pele dos pacientes com ES precoce, pode-se observar um padrão semelhante aos controles na derme (figura 10D) e ao longo da membrana basal (figura 10E, setas). Entretanto, o depósito de COLI foi mais proeminente na parede dos pequenos vasos (figura 10F, setas). Já na doença tardia, foram observadas fibras espessadas de COLI, densamente agregadas desde a membrana basal (figura 10G-10H, setas) até a derme reticular (figura 10G), envolvendo inclusive os vasos (figura 10l, setas) e modificando a histoarquitetura habitual da derme.

A quantificação do COLI confirmou estes dados, mostrando aumento da expressão deste tipo de colágeno na derme dos pacientes com doença tardia, quando comparados aos controles e aos pacientes com doença precoce (tabela 6). Além disso, observou-se correlação positiva entre a expressão de COLI e a duração da doença em meses (tabela 7). 

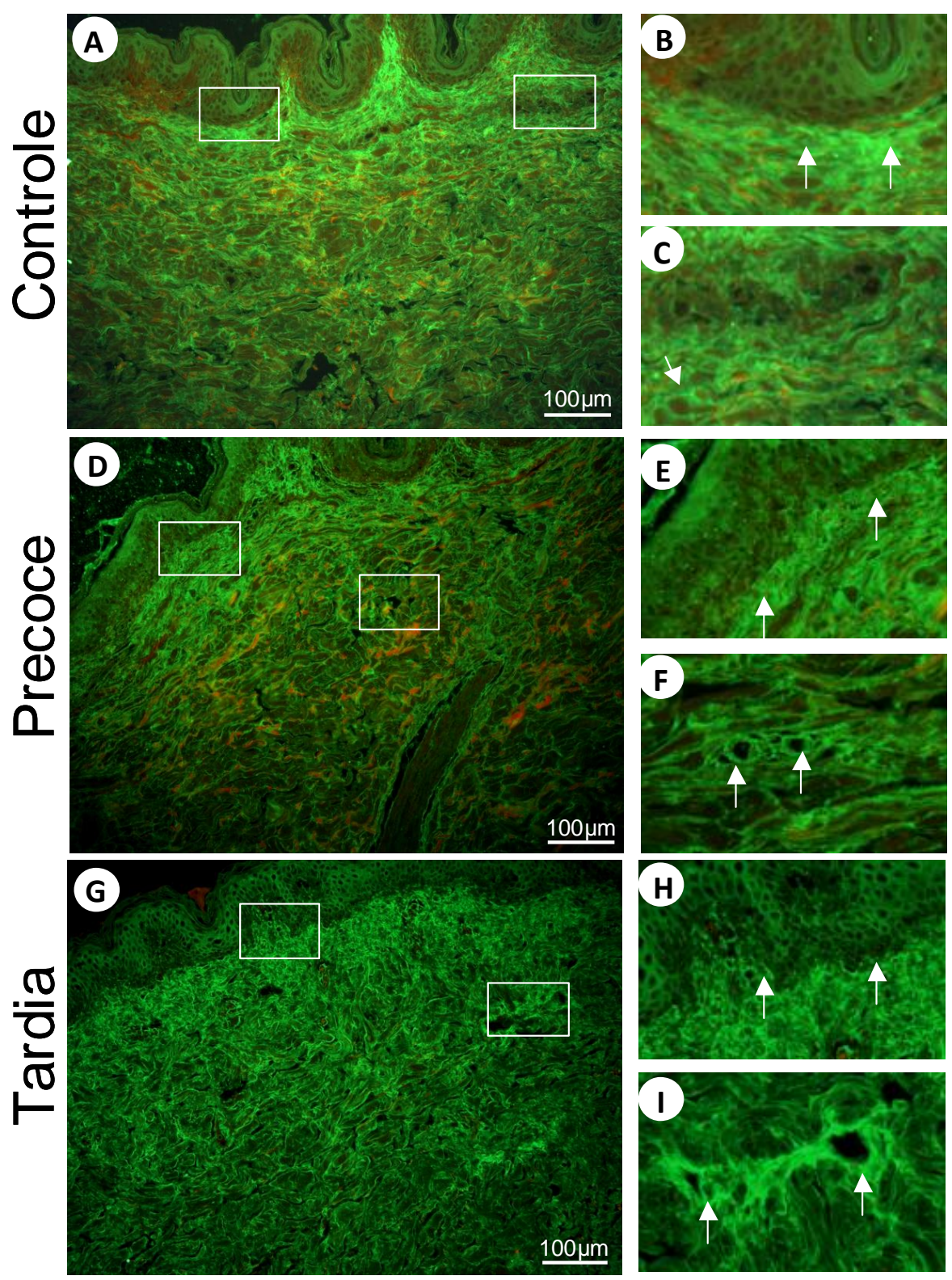

Figura 10 - Imunomarcação do COLI na derme de pacientes com ES e controles. A-C: Derme de controle saudável apresentando fibras de COLI coradas em verde, assumindo aspecto em cesto de vime na derme (A), em arranjos frouxos ao longo da membrana basal (B,setas) e, às vezes, ao redor dos pequenos vasos (C, setas). D-F: ES precoce apresentando padrão em cesto de vime semelhante aos controles na derme (D), em arranjos frouxos ao longo da membrana basal $(E)$ e, em contraste com os controles, deposição mais proeminente ao redor dos vasos (F). G-I: ES tardia apresentando fibras de COLI densamente agregadas na derme $(G)$, ao longo da membrana basal $(\mathrm{H})$ e ao redor dos vasos (I), diferente dos controles e da ES precoce. (aumento de 200X). 
Já o COLIII foi visualizado como fibras finas predominantemente ao redor dos pequenos vasos da pele (figura 11A-11C, setas) e de maneira esparsa na derme, não sendo observado na membrana basal (figura 11B, setas) dos controles. Na derme dos pacientes com ES precoce, as fibras finas deste tipo de colágeno também se distribuem ao redor dos vasos (figura 11D -11F, setas), porém de maneira irregular ao longo da membrana basal (figura 11E, setas), permeando difusamente a derme papilar e reticular (figura 11D). Na pele dos pacientes com ES tardia, as fibras finas do COLIII apresentaram distribuição homogênea e linear ao longo da membrana basal (figura 11G-11H, setas), ao redor dos pequenos vasos (Figura 11I), permeando a derme reticular (figura $11 G)$.

A expressão do COLIII é maior na pele dos pacientes com doença precoce, quando comparados aos controles (tabela 6). Entretanto, não houve diferença quando se comparou os pacientes com doença tardia aos controles e aos pacientes com doença precoce. Também não se observou correlação entre a deposição de COLIII e a duração da doença em meses (tabela 7). 


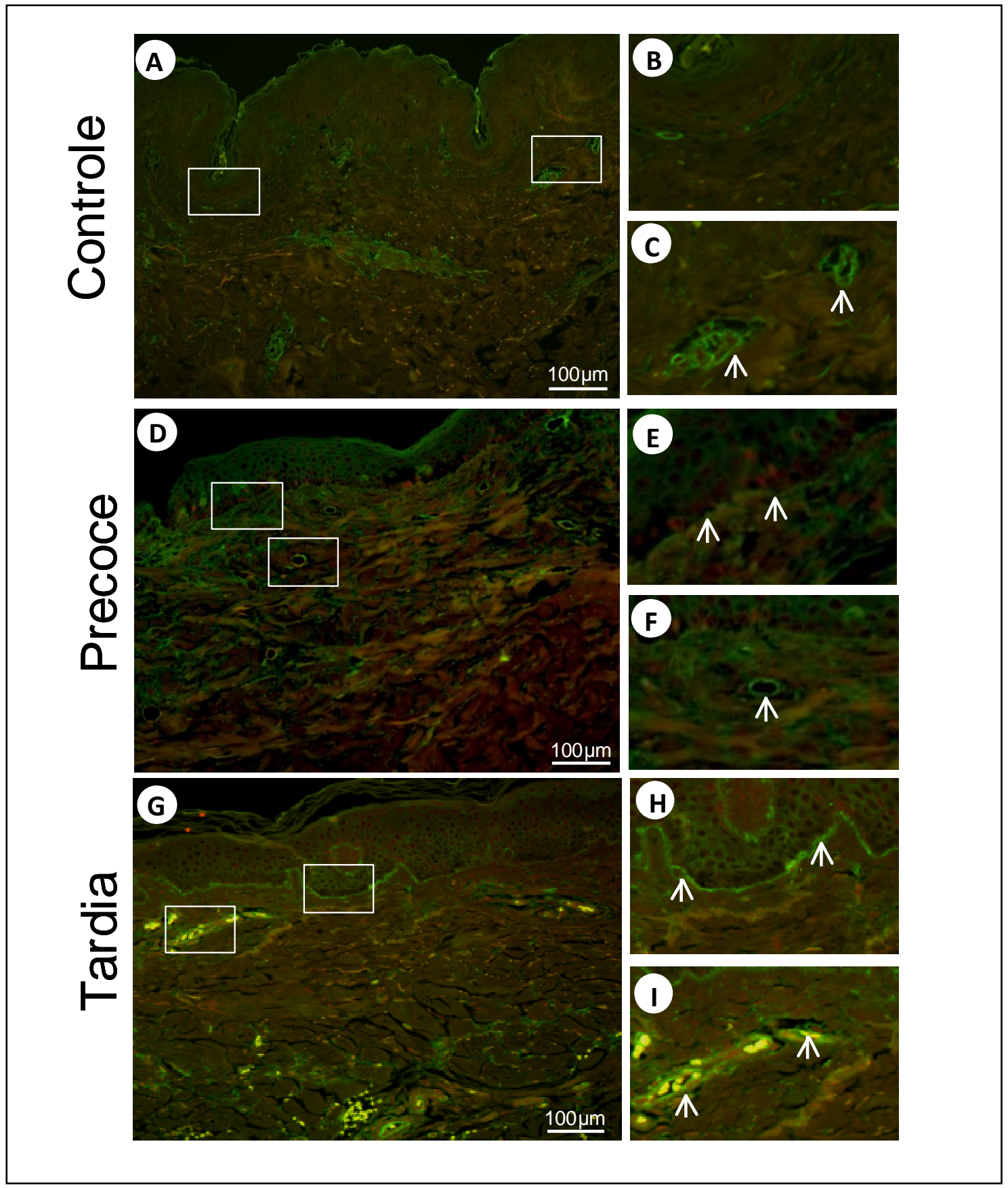

Figura 11 - Imunomarcação do COLIII na derme de pacientes com ES e controles. A-C: Derme de controle saudável apresentando COLIII corado em verde com aspecto de fibras finas, depositado predominantemente ao redor dos pequenos vasos ( $A, C$, setas) e distribuído de maneira esparsa na derme (A); não se encontra depositado na membrana basal (B) D-F: ES precoce apresentando fibras finas ao redor dos vasos ( $F$,setas), porém, ao contrário dos controles, este colágeno apresenta-se distribuído de maneira mais intensa em toda derme (D) e ao longo da membrana basal (E,setas). G-I: ES tardia apresentando fibras finas distribuídas ao longo da membrana basal $(H$, setas), em toda derme, mas principalmente na derme reticular $(G)$ e ao redor dos vasos (I, setas). (Aumento de 200X) 
Em síntese, a expressão de COLV foi maior nos pacientes com ES em ambos os estágios da doença, quando comparados aos controles. Notadamente, a deposição de COLV foi maior nos pacientes com doença precoce, quando comparados àqueles com doença tardia. Observou-se correlação inversa entre a densidade de COLV e o tempo de duração da ES. Por outro lado, os pacientes com ES tardia apresentaram maior expressão de COLI, quando comparados aos controles e aos pacientes com doença precoce. Ao contrário do COLV, observou-se correlação positiva entre a duração da doença e a densidade de COLI. Em relação ao COLIII, houve maior expressão desta proteína nos pacientes com doença precoce, quando comparados aos controles, porém não se observou correlação entre a densidade desta proteína e a duração da ES (tabelas 6 e 7). 
Tabela 6 - Análise estatística da expressão dos colágenos I, III e V entre os grupos controle, doença precoce e doença tardia

\begin{tabular}{|c|c|c|c|}
\hline & Grupo $(n)$ & Grupo (n) & $p^{1}$ \\
\hline & Mediana (min-máx) & Mediana (min-máx) & \\
\hline \multirow[t]{6}{*}{$\%$ COLV } & Controle (10) & Precoce (6) & $<0,001^{*}$ \\
\hline & $24,61(13,61-36,06)$ & $47,67(20,09-69,91)$ & \\
\hline & & Tardio (12) & $0,04^{*}$ \\
\hline & & $32,21(27,76-41,12)$ & \\
\hline & Precoce (6) & Tardio (12) & $0,012^{*}$ \\
\hline & $47,67(20,09-69,91)$ & $32,21(27,76-41,12)$ & \\
\hline \multirow[t]{6}{*}{$\%$ COLI } & Controle (10) & Precoce (6) & 1 \\
\hline & $41,11(30,42-48,34)$ & $40,65(37,65-44,92)$ & \\
\hline & & Tardio (12) & $0,001^{*}$ \\
\hline & & $52,57(39,41-72,02)$ & \\
\hline & Precoce (6) & Tardio (12) & $0,002^{*}$ \\
\hline & $40,65(37,65-44,92)$ & $52,57(39,41-72,02)$ & \\
\hline \multirow[t]{6}{*}{$\%$ COLIII } & Controle (10) & Precoce (6) & $0,008^{*}$ \\
\hline & $4,93(3,32-8,16)$ & $10,95(4,88-18,12)$ & \\
\hline & & Tardio (12) & 0,209 \\
\hline & & $6,99(4,82-17,01)$ & \\
\hline & Precoce (6) & Tardio (12) & 0,309 \\
\hline & $10,95(4,88-18,12)$ & $6,99(4,82-17,01)$ & \\
\hline
\end{tabular}

1- os grupos foram comparados utilizando-se o teste de Kruskall-Wallis e posteriomente foram realizadas comparações múltiplas 
Tabela 7 - Coeficientes de correlação entre a expressão dos colágenos I, III e $\checkmark$ e o tempo de doença em meses

\begin{tabular}{ccc}
\hline & $\mathrm{r}^{1}$ & $\mathrm{p}$ \\
\hline COLV & $-0,44$ & $0,032^{\star}$ \\
COLI & 0,59 & $0,015^{\star}$ \\
COLIII & 0,086 & 0,390 \\
\hline 1 - as associações foram testadas pelo coeficiente de Spearman &
\end{tabular}

\subsection{Correlação entre espessamento cutâneo, atividade de doença e expressão de colágeno V na derme de pacientes com ES}

Para avaliar a relevância clínica da expressão de COLV na derme de pacientes com ES, foi pesquisada a presença de correlação entre a densidade deste colágeno e o espessamento cutâneo, assim como da atividade de doença avaliada pelo índice de atividade de Valentini. A título de comparação, também se pesquisou a correlação entre a expressão de COLI e COLIII com estas variáveis.

Nesse sentido, foi encontrada correlação positiva entre a densidade de COLV e o MRSS, assim como com o índice de atividade de Valentini. Por outro lado, não houve correlação entre a expressão de COLI e COLIII com o espessamento cutâneo ou com o grau de atividade de doença (tabela 8). 
Tabela 8 - Correlação entre espessamento cutâneo, atividade de doença e expressão de COLV, COLI e COLIII na derme de pacientes com ES

\begin{tabular}{ccccc}
\hline Variável & \multicolumn{2}{c}{ MRSS } & \multicolumn{2}{c}{ Índice de Atividade de Valentini } \\
\hline & $\mathrm{r}^{1}$ & $\mathrm{p}$ & $\mathrm{r}^{1}$ & $\mathrm{p}$ \\
COLV & 0,42 & $0,04^{*}$ & 0,45 & $0,03^{*}$ \\
COLI & $-0,2$ & 0,23 & $-0,03$ & 0,44 \\
COLIII & $-0,16$ & 0,18 & $-0,05$ & 0,42
\end{tabular}

1 - as associações foram testadas pelo coeficiente de Spearman

Considerando-se que houve correlação inversa entre o depósito de COLV e o tempo de duração da doença, foi realizada regressão linear para avaliar se o COLV interagiu simultaneamente sobre a duração da doença, sobre o índice de atividade de Valentini e sobre o MRSS. Esta análise demonstrou que a duração e o índice de atividade de Valentini estavam associados de maneira independente com a expressão de COLV (tabela 9).

Tabela 9 - Interação do COLV com duração da doença, MRSS e índice de atividade de Valentini

\begin{tabular}{lccc}
\hline & coeficiente & erro padrão & $p$ \\
\hline Duração & $-6,13$ & 2,47 & $0,0276^{*}$ \\
MRSS & 0,05 & 0,09 & 0,5987 \\
Indice de atividade de Valentini & 5,84 & 2,10 & $0,0156^{*}$ \\
\hline
\end{tabular}

Análise de regressão linear generalizada 


\subsection{Reconstrução tridimensional dos colágenos I, IIII e V na cultura de fibroblastos dérmicos}

Foram realizados estudos in vitro por meio de cultura de fibroblastos dérmicos, já que estas células reproduzem importantes alterações moleculares, responsáveis pelo fenótipo pró-fibrótico observado na ES. A reconstrução tridimensional foi realizada para avaliar a histoarquitetura e a distribuição espacial das fibras de colágeno sem a interferência de componentes teciduais. Nos pacientes com ES, tanto com doença precoce como com doença tardia, as fibras de COLV, imunomarcadas em verde, aparecem espessadas, distorcidas e organizadas em agregados densos (figura 12A), diferente do observado nos controles, nos quais estas fibras são finas e estão distribuídas paralelas umas às outras (figura 12B).

A dupla marcação de COLV (verde) e de COLI (vermelho) mostrou que nos pacientes com ES estes colágenos formam agregados irregulares (figura 12C) e que tanto as fibras de COLV como as de COLI estão espessadas, diferente dos controles, em que podem ser observadas fibras finas, distribuídas paralelamente umas às outras (figura 12D). Em relação à dupla marcação do COLV (verde) e de COLIII (vermelho), observou-se que as fibras de COLIII são finas, tanto nos pacientes como nos controles (figura 12E e 12F); entretanto, nos pacientes com ES, viu-se que o COLV está distribuído de forma paralela 
ao COLIII, enquanto nos controles estas fibras parecem se entrelaçar, apresentando um padrão reticulado, formando uma malha fina.

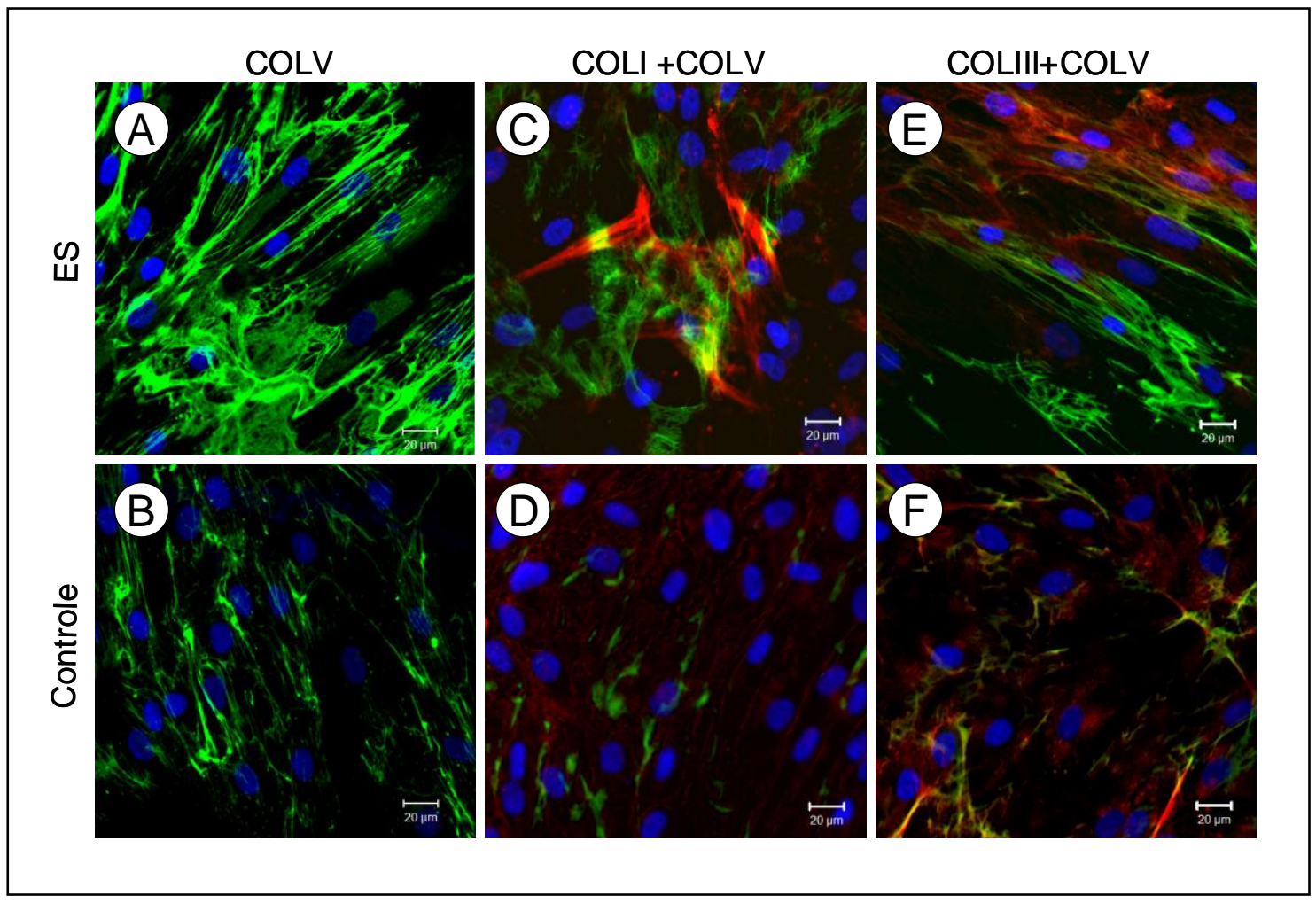

Figura 12 - Reconstrução tridimensional das fibras heterotípicas presentes na cultura de fibroblastos dérmicos. (A-F): reconstrução tridimensional do COLI, COLIII (corados em vermelho) e COLV (corado em verde) (A): na ES, as fibras de COLV estão espessadas, distorcidas e organizadas em malhas densas. (B): nos controles, ao contrário, as fibras do COLV são finas e distribuídas de forma paralela umas às outras. (C): na ES, as fibras de COLI também estão espessadas, formando agregados com as fibras de COLV. (D): nos controles, as fibras de COLI são finas e paralelas às fibras de COLV. (E, F): as fibras de COLIII são finas, tanto nos pacientes com ES quanto nos controles; entretanto, na ES, as fibras de COLIII estão distribuídas em paralelo com as fibras de COLV (E), enquanto nos controles estas fibras parecem se entrelaçar, formando uma malha fina $(\mathbf{F})$. 


\subsection{Expressão dos genes das cadeias a dos colágenos V, I e III obtidos da cultura de fibroblastos dérmicos}

O mRNA total extraído de fibroblastos dérmicos, cultivados a partir de biópsias de pele de pacientes e controles, foi utilizado para avaliar a expressão de RNA das cadeias a de COLI, COLIII e COLV, por meio de RT-PCR em tempo real. Conforme esperado, a expressão gênica de ambas as cadeias $\alpha$ de COLV foi aumentada em pacientes com ES, havendo uma expressão de 2,2 vezes $(p=0,02)$ e 5,9 vezes maior $(p<0,01)$, respectivamente, para o gene das cadeias $\operatorname{COLV} \alpha_{1}$ e COLV $\alpha_{2}$ dos pacientes, em relação às mesmas cadeias dos controles (gráfico 1).

Da mesma forma, pacientes com ES apresentaram expressão do gene da cadeia COLl $\alpha_{1} 4,5$ vezes aumentada em relação aos controles $(p=0,01)$, assim como expressão do gene da cadeia COLIII $\alpha_{1} 2,9$ vezes maior do que dos controles $(p<0,01)$ (gráfico 1). 
Gráfico 1- Quantificação por RT-PCR em tempo real dos genes das cadeias a dos colágenos $\mathrm{V}$, I e III obtidos da cultura de fibroblastos dérmicos

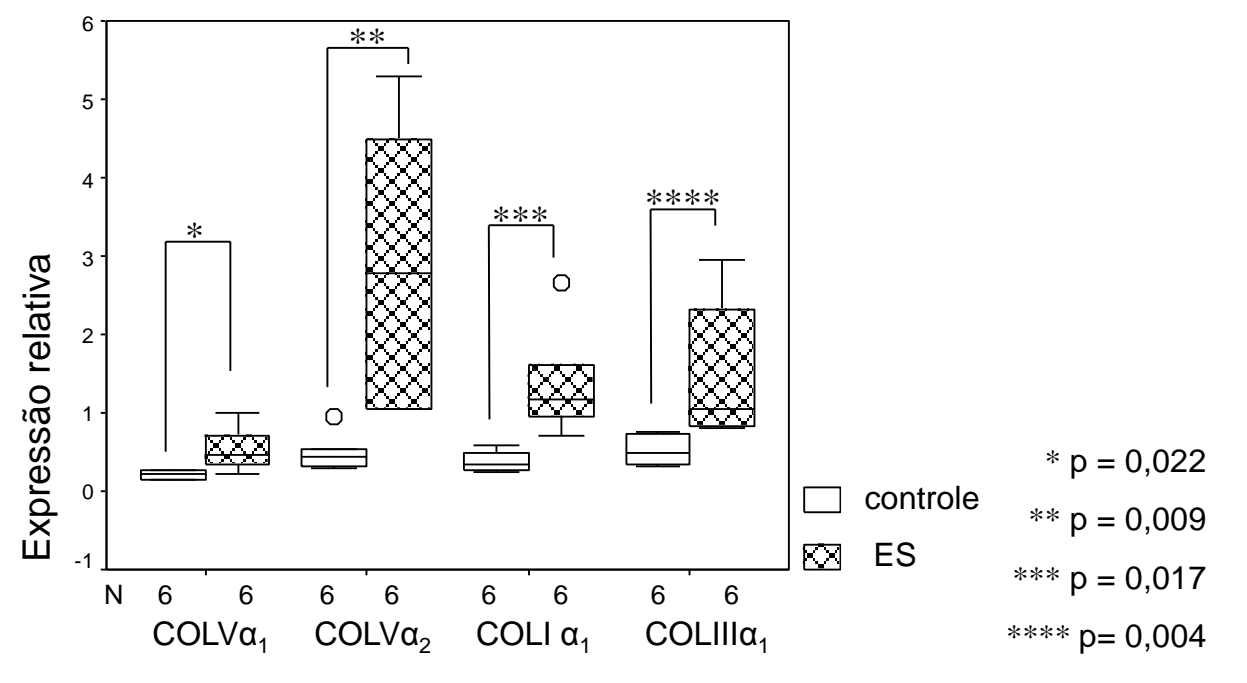

\subsection{Eletroforese e immunoblot do colágeno V extraído do sobrenadante da cultura de fibroblastos dérmicos}

Para verificar se o aumento da expressão gênica das cadeias $\alpha$ do COLV resulta em aumento da expressão de COLV no sobrenadante da cultura de fibroblastos dérmicos, foram realizadas eletroforese e immunoblot. A análise dos resultados destes testes confirmaram o aumento da produção das cadeias $\mathrm{COLVa}_{1}$ e COLVa${ }_{2}$. Comparando-se o perfil de corrida do padrão de peso molecular com o perfil de corrida do colágeno total de pacientes com ES e do grupo controle, é possível identificar as bandas correspondentes aos pesos 
moleculares das cadeias $\operatorname{COLV} \alpha_{1}, \operatorname{COLV} \alpha_{2}$ e COLl $\alpha_{1}$, respectivamente, conforme observado na figura 13A. O immunoblot confirma os achados da eletroforese em gel de poliacrilamida, mostrando imunomarcação mais intensa nas áreas correspondentes às cadeias $\operatorname{COLV} \alpha_{1}$ e $\operatorname{COLV} \alpha_{2}$ nos pacientes com ES (figura $13 \mathrm{~B})$. 


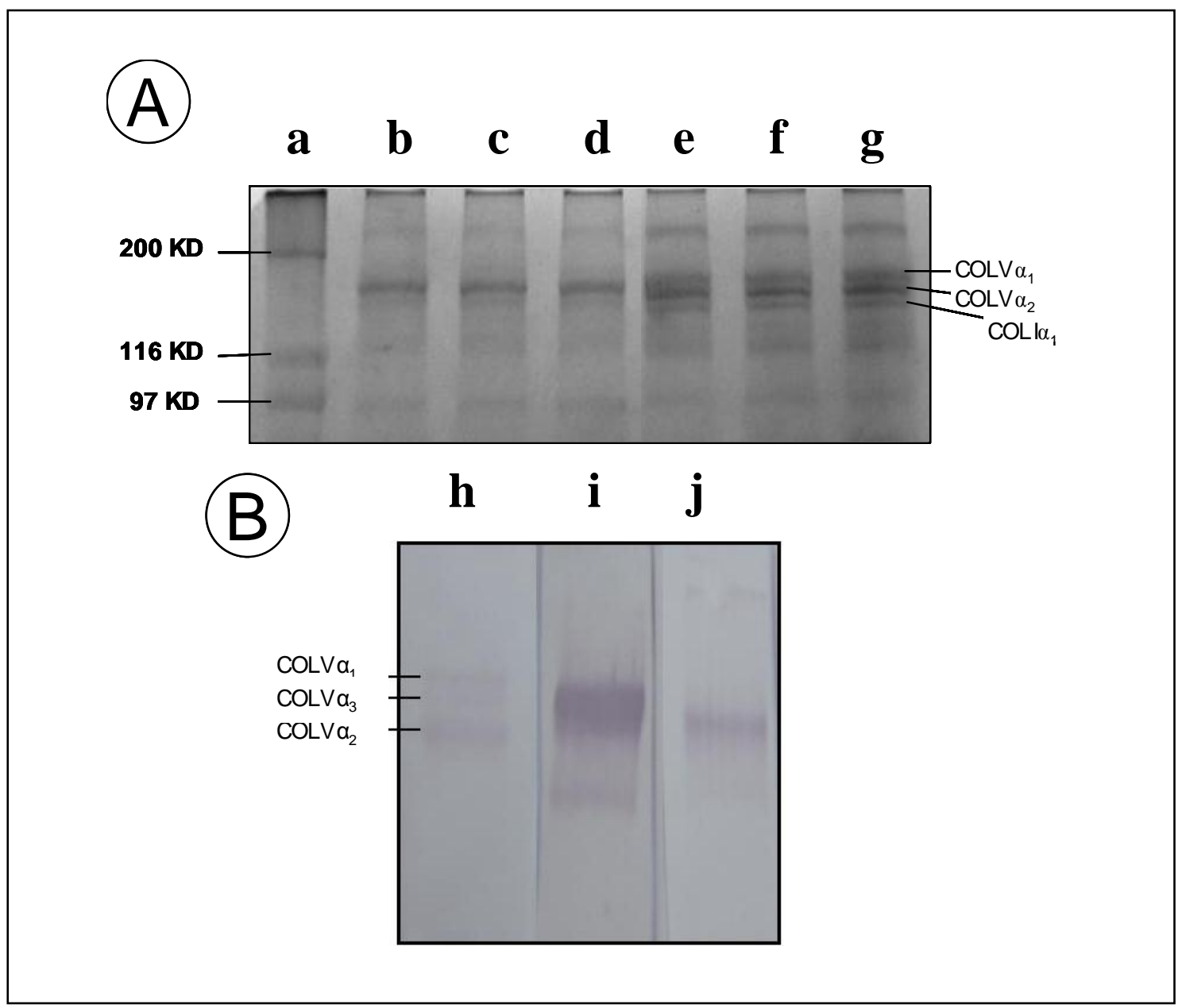

Figura 13 - Eletroforese e immunoblot do COLV extraído da cultura de fibroblastos dérmicos. (A) Eletroforese em gel de poliacrilamida 7,5\% na presença de SDS do colágeno total isolado do meio de cultura de fibroblastos dérmicos de pacientes e controles: em a - Padrão de peso molecular (Sigma); em b, c e $\mathbf{d}$ - controles; em e, $\mathbf{f}$ e $\mathbf{g}$ - pacientes com ES. Notar as bandas correspondentes às cadeias COLV $\alpha_{1}, C O L V \alpha_{2}$ e COLl $\alpha_{1}$. (B) Immunoblot do colágeno total isolado do meio de cultura de fibroblastos dérmicos de pacientes e controles: em h, Padrão (COLV sigma); em i, paciente com ES; em j, controle. Observar a imunomarcação mais intensa nas áreas correspondentes às cadeias $C O L V \alpha_{1}$ e $C O L V \alpha_{2}$ nos pacientes com ES. 


\subsection{Quantificação de marcadores de apoptose e de ativação endotelial nas células endoteliais dérmicas de pacientes com ES e de controles}

Para verificar a correlação entre o depósito de COLV com apoptose e a ativação de células endoteliais, procedeu-se à quantificação de caspase-3, ET1, TGF $\beta$, CTGF e VEGF nas células endoteliais de pacientes com ES e controles.

A imunomarcação para caspase-3, ET1, CTGF e TGF $\beta$ nas células endoteliais foi maior nos pacientes com ES, tanto na fase precoce quanto na fase tardia, quando comparados aos controles. Entretanto, não foi observada diferença entre a expressão destes marcadores nos dois estágios da doença, (tabela 10).

A expressão de VEGF foi maior nos pacientes com doença tardia, quando comparados aos controles. Entretanto, não houve diferença na expressão deste marcador quando os pacientes com doença precoce foram comparados aos pacientes com doença tardia (tabela 10). 
Tabela 10 - Análise estatística da expressão dos marcadores de apoptose e de ativação endotelial na derme dos grupos ES precoce e tardio e controle

\begin{tabular}{|c|c|c|c|}
\hline \multirow[t]{2}{*}{ Marcador } & Grupo (n) & Grupo (n) & \multirow[t]{2}{*}{$p^{1}$} \\
\hline & Mediana (min-máx) & Mediana (min-máx) & \\
\hline \multirow[t]{6}{*}{ Caspase-3 } & Controle (10) & Precoce (4) & $0,004^{*}$ \\
\hline & $26,66 \%(14,81-60,00)$ & $67,00 \%(88,33-48,33)$ & \\
\hline & & Tardio (9) & $0,001^{*}$ \\
\hline & & $64,29 \%(81,25-42,36)$ & \\
\hline & Precoce (4) & Tardio (9) & 1 \\
\hline & $67,00 \%(88,33-48,33)$ & $64,29 \%(81,25-42,36)$ & \\
\hline \multirow[t]{6}{*}{ ET1 } & Controle (9) & Precoce (6) & $0,024^{*}$ \\
\hline & $1,55 \%(2,50-1,00)$ & $2,8 \%(1,90-5,15)$ & \\
\hline & & Tardio (9) & $0,035^{*}$ \\
\hline & & $2,55 \%(0,86-4,85)$ & \\
\hline & Precoce (6) & Tardio (9) & 0,684 \\
\hline & $2,8 \%(1,90-5,15)$ & $2,55 \%(0,86-4,85)$ & \\
\hline \multirow[t]{6}{*}{ CTGF } & Controle (6) & Precoce (4) & $0,001^{*}$ \\
\hline & $31,16 \%(14,81-49,16)$ & $62,12 \%(56,67-70,83)$ & \\
\hline & & Tardio (11) & $0,008^{*}$ \\
\hline & & $56,67 \%(33,33-66,66)$ & \\
\hline & Precoce (4) & Tardio (11) & 0,293 \\
\hline & $62,12 \%(56,67-70,83)$ & $56,67 \%(33,33-66,66)$ & \\
\hline \multirow[t]{6}{*}{ TGF $\beta$} & Controle (7) & Precoce (4) & $0,030^{*}$ \\
\hline & $35,00 \%(3,33-48,33)$ & $58,33 \%(31,67-86,67)$ & \\
\hline & & Tardio (12) & $0,021^{*}$ \\
\hline & & $51,67 \%(35,00-71,67)$ & \\
\hline & Precoce (4) & Tardio (12) & 1 \\
\hline & $58,33 \%(31,67-86,67)$ & $51,67 \%(35,00-71,67)$ & \\
\hline \multirow[t]{6}{*}{ VEGF } & Controle (9) & Precoce (5) & 0,809 \\
\hline & $33,33 \%(20,00-56,57)$ & $38,33 \%(23,14-65,00)$ & \\
\hline & & Tardio (8) & $0,032^{*}$ \\
\hline & & $51,66 \%(35,00-65,00)$ & \\
\hline & Precoce (5) & Tardio (8) & 0,621 \\
\hline & $38,33 \%(23,14-65,00)$ & $51,66 \%(35,00-65,00)$ & \\
\hline
\end{tabular}

1- os grupos foram comparados através do teste de Kruskall-Wallis e posteriomente foram realizadas comparações múltiplas 
Foi verificada a presença de correlação positiva entre a expressão de caspase-3, ET1 e CTGF nas células endoteliais com a deposição de COLV na derme. Entretanto, não houve correlação entre a deposição deste colágeno na matriz extracelular com a imunomarcação para TGF $\beta$ e o VEGF nas células endoteliais (tabela 11).

Tabela 11 - Correlação entre expressão do COLV na derme, com os marcadores de apoptose e de ativação endotelial

\begin{tabular}{lcc}
\hline Marcador & $\mathrm{r}^{1}$ & $\mathrm{p}$ \\
\hline Caspase-3 & 0,5035 & 0,012 \\
Endotelina & 0,451 & 0,013 \\
CTGF & 0,384 & 0,043 \\
TGF $\beta$ & 0,184 & 0,225 \\
VEGF & 0,189 & 0,199
\end{tabular}

1- as correlações foram testadas por meio do coeficiente de Pearson.

\subsection{Avaliação do modelo animal de esclerose sistêmica induzido pela imunização com colágeno V}

Com a finalidade de avaliar se o COLV está envolvido com apoptose e com ativação endotelial no modelo animal de ES induzido pela imunização com COLV, a expressão deste colágeno, bem como de caspase-3, ET1, CTGF, TGF $\beta$ e VEGF, foi analisada também nos animais COLV-IM e em coelhos controles imunizados apenas com adjuvante de Freund. 
A análise morfológica das amostras de pele dos animais do grupo controle (figura 14A e B) demonstrou manutenção da histoarquitetura da derme e preservação da matriz extracelular. Os anexos cutâneos estavam preservados (Anex), assim como a camada de tecido adiposo presente na derme profunda. Por outro lado, animais COLV-IM exibiram, precocemente, a partir do sétimo dia após a primeira imunização, remodelamento da matriz extracelular, com piora progressiva até 210 dias. Neste estágio, notou-se diminuição da derme papilar, atrofia de anexos e presença de depósito de colágeno na derme reticular e profunda, bem como ao redor de vasos sanguíneos e anexos, evidenciando um padrão histológico típico de ES, conforme previamente descrito (Bezerra, 2006; de Oliveira, 2009) (figura 14 CD). 


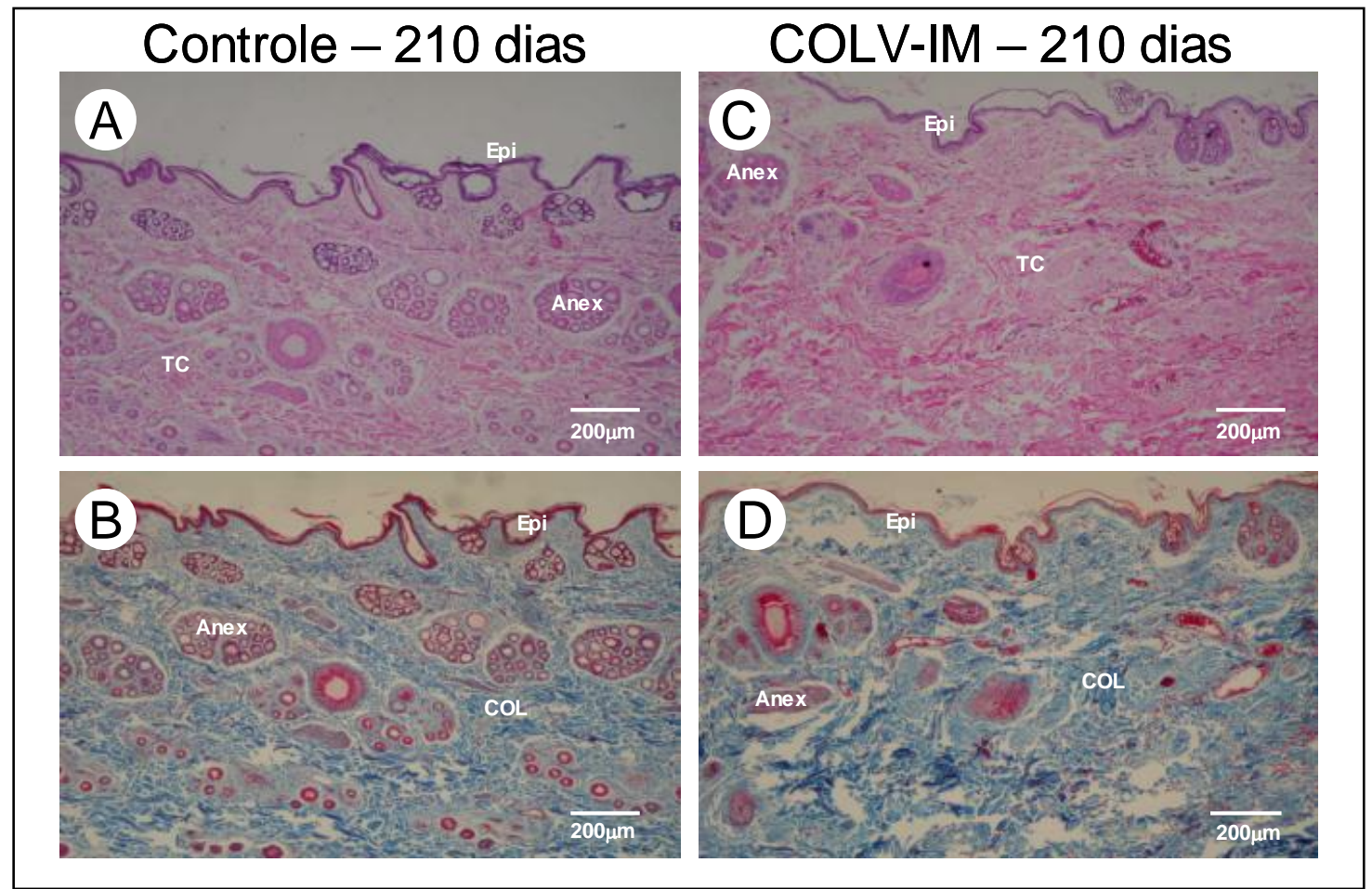

Figura 14- Aspecto histológico da pele de animais controles e de imunizados com COLV. Observa-se em A e B o aspecto normal da epiderme (Epi), a presença de anexos (Anex) e da quantidade normal de colágeno (COL) no tecido conjuntivo (TC). Já nos animais imunizados pode-se visualizar diminuição dos anexos e aumento da quantidade de colágeno no tecido conjuntivo (TC), distorcendo a histoarquitetura normal da derme. Coloração com Hematoxilina e Eosina: A e C; coloração com Tricrômico de Masson: B e D. Magnificação $=100 \mathrm{X}$ 


\subsubsection{Expressão do colágeno $V$ na derme de animais COLV- IM e de animais controle}

Nos animais pertencentes ao grupo controle, foram observadas fibras finas de COLV, imunomarcadas em verde, (figura 15A e B) distribuídas de maneira esparsa na derme e depositadas na adventícia dos vasos (setas). Por outro lado, os animais do grupo COLV-IM apresentaram fibras grossas de COLV, depositadas difusamente na derme e na adventícia dos vasos (setas), fenômeno notado a partir do sétimo dia após a primeira imunização e que se manteve até os 210 dias (figura 15C e D). 


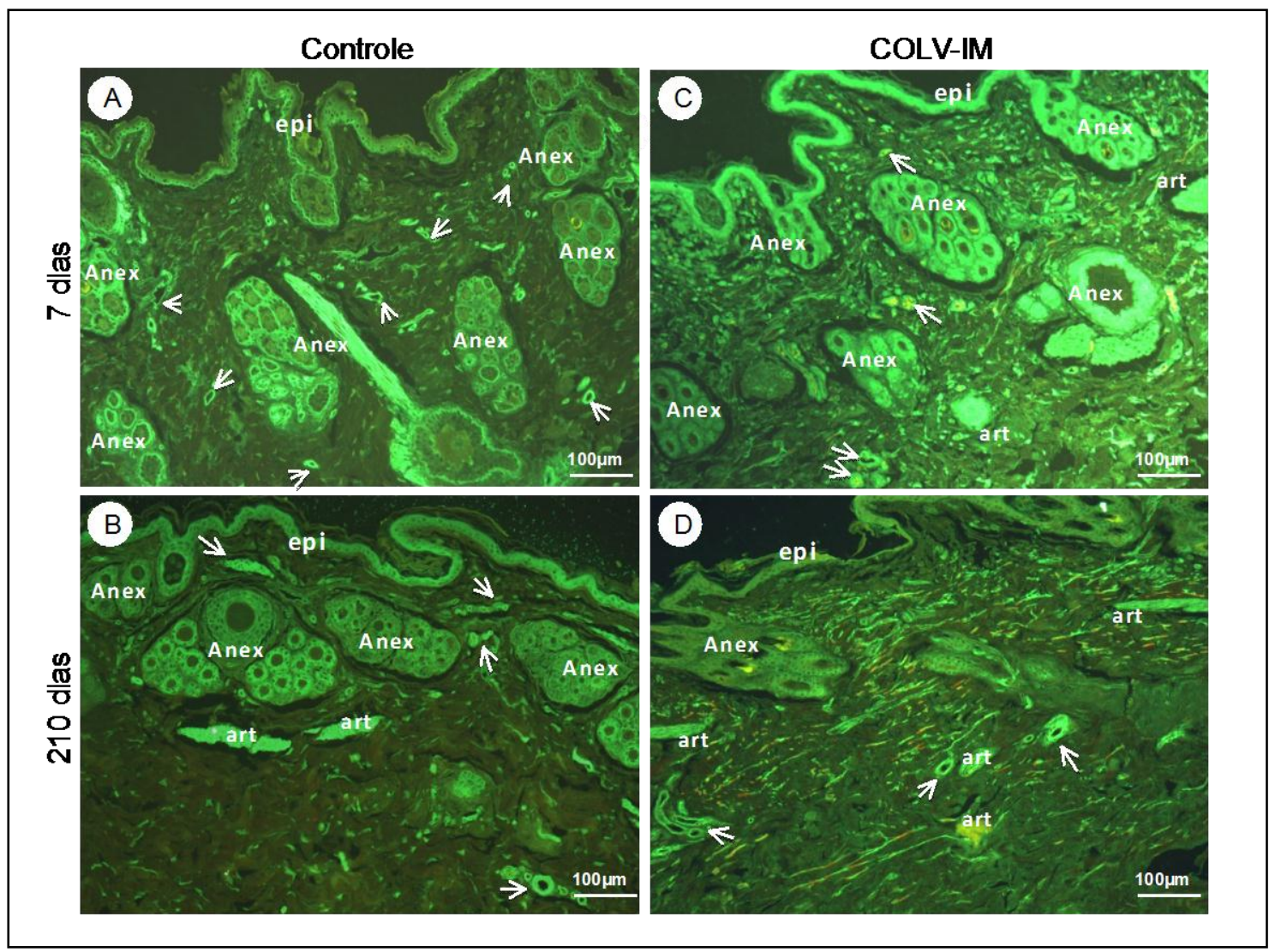

Figura 15 - Expressão de COLV na derme dos animais controle e COLV-IM. Nos coelhos controle, aos 7 (A) e 210 dias (B) após a primeira imunização, observa-se deposição de fibras finas de COLV coradas em verde claro, distribuídas de maneira esparsa na derme e na adventícia dos vasos (setas), enquanto nos animais COLV-IM, já aos 7 dias (C), há deposição de fibras grossas de COLV por toda derme, distribuídas difusamente, presentes também na adventícia dos vasos (setas), aspecto que se mantém aos 210 dias (D). Aumento de 200X. Epi: epiderme; Anex: anexos cutâneos; art: artefatos.

A análise quantitativa mostrou que aos 7 dias após a primeira imunização o depósito de COLV é maior nos animais COLV-IM, quando comparados aos controles $(p=0,004)$, resultado que se mantém 30 dias após a primeira imunização, porém sem diferença estatística significativa. Aos 75 dias, o depósito de COLV é semelhante em ambos os grupos. Porém, aos 210 dias 
após a primeira imunização, os animais COLV-IM voltam a apresentar maior depósito de COLV (gráfico 2).

Ao analisar o depósito de COLV ao longo do tempo, observa-se que em ambos os grupos ocorre maior expressão aos 7 dias, diminuindo aos 30 dias e voltando a aumentar aos 75 dias após a primeira imunização. Entretanto, aos 210 dias, a expressão de COLV permanece aumentada no grupo COLV-IM, enquanto diminui no grupo controle (gráfico 2).

$\mathrm{Na}$ tabela 12, podem ser observados os valores das medianas e do intervalo abrangendo os valores máximos e mínimos observados nos diferentes grupos de animais estudados. 
Tabela 12 - Expressão do colágeno $V$ dérmico nos diferentes grupos de animais estudados

\begin{tabular}{ccccc}
\hline Grupo & tempo & mediana & mínimo & máximo \\
\hline Controle & 7 dias & $13,85 \%$ & $7,86 \%$ & $18,11 \%$ \\
COLV-IM & 7 dias & $19,29 \%$ & $14,70 \%$ & $26,25 \%$ \\
Controle & 30 dias & $11,97 \%$ & $7,52 \%$ & $19,58 \%$ \\
COLV-IM & 30 dias & $16,80 \%$ & $12,95 \%$ & $21,46 \%$ \\
Controle & 75 dias & $18,15 \%$ & $12,84 \%$ & $20,66 \%$ \\
COLV-IM & 75 dias & $20,14 \%$ & $14,20 \%$ & $23,68 \%$ \\
Controle & 210 dias & $14,89 \%$ & $13,63 \%$ & $18,84 \%$ \\
COLV-IM & 210 dias & $22,29 \%$ & $11,84 \%$ & $22,84 \%$ \\
\hline
\end{tabular}

Gráfico 2 - Expressão de COLV na derme de coelhos COLV-IM e de controles

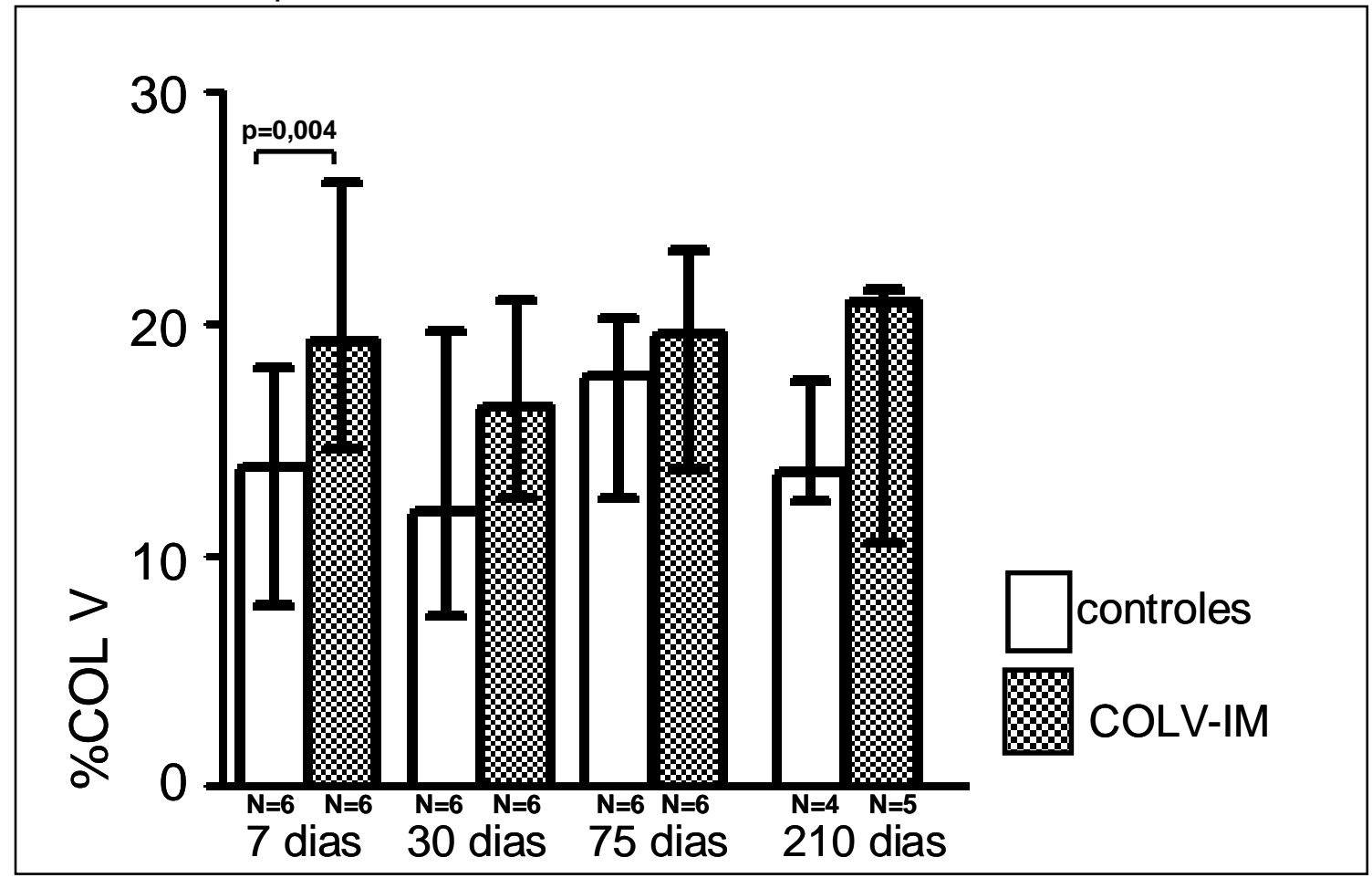

* as barras indicam as medianas e as retas os valores máximos e mínimos observados. Os grupos foram comparados por meio de teste de Kruskal-Wallis e posteriormente foram realizadas comparações múltiplas 


\subsubsection{Expressão de marcadores de apoptose e de ativação endotelial nas células endoteliais dérmicas de animais COLV- IM e de controles}

Da mesma forma que se procedeu com os pacientes com ES e controles, foram quantificados marcadores de apoptose (caspase-3) e de ativação endotelial (ET1, CTGF e TGF $\beta$ e VEGF1) nas células endoteliais dérmicas dos animais COLV-IM e dos animais controle.

Quanto à caspase-3, ao comparar-se os grupos COLV-IM e controle, percebeu-se maior expressão deste marcador aos 7 e aos 210 dias após a primeira imunização nos animais COLV-IM, enquanto aos 30 e aos 75 dias a expressão foi maior nos coelhos do grupo controle. Quando os animais são comparados ao longo do tempo, nos coelhos COLV-IM a expressão de caspase-3 é maior aos 7 dias, tendendo a cair aos 30 dias e voltando a subir a partir dos 75 dias, mantendo-se elevada aos 210 dias após a primeira imunização. Já no grupo controle, observa-se aumento progressivo com ápice aos 75 dias, que não se mantém aos 210 dias após a primeira imunização (gráfico 3). Entretanto, estas diferenças não foram estatisticamente significativas. 
Grafico 3- Expressão de caspase-3 nas células endotelias dérmicas de coelhos COLV-IM e de controles

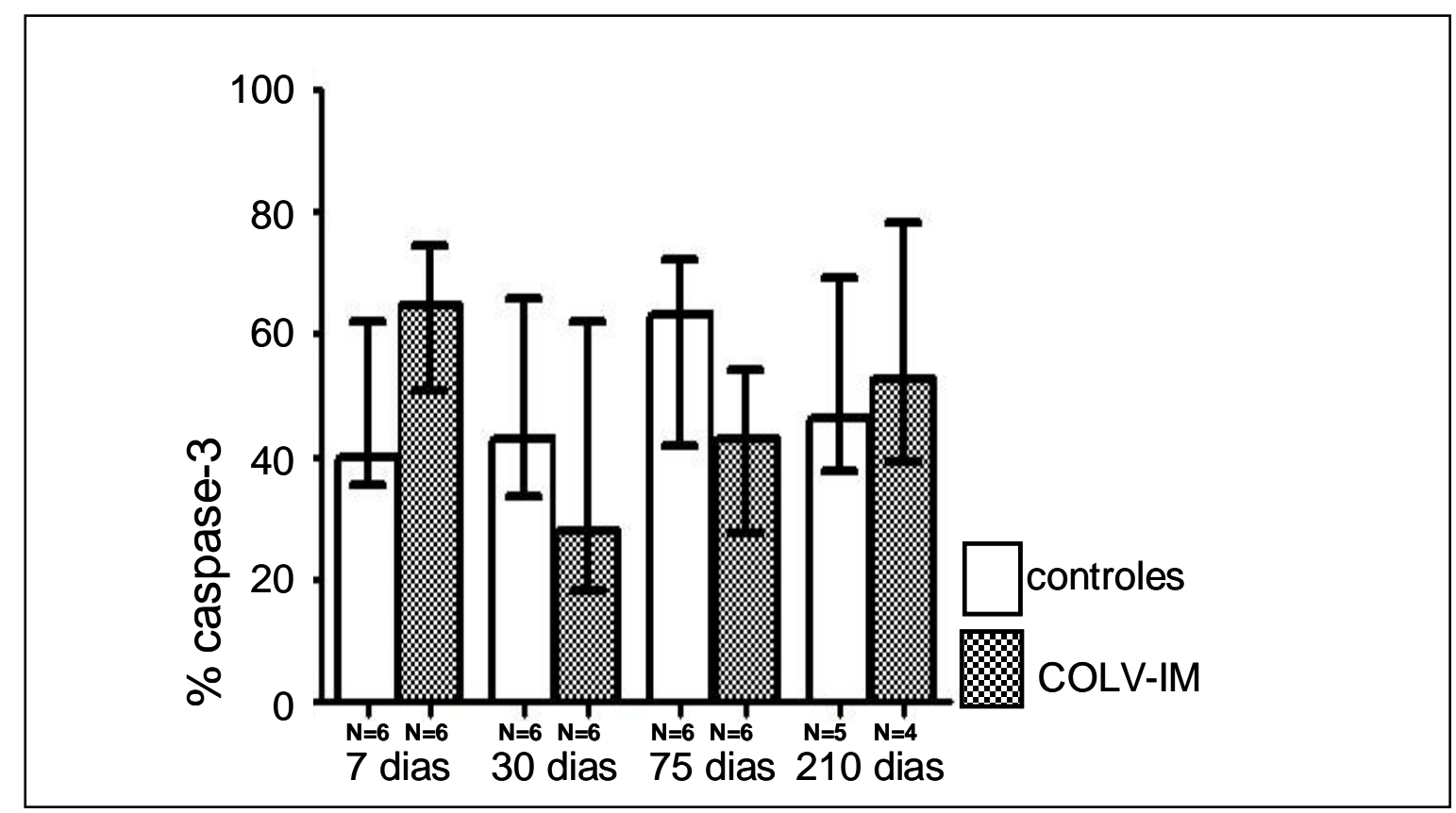

* as barras indicam as medianas e as retas o intervalo abrangendo os valores máximos e mínimos observados. Os grupos foram comparados pelo teste de Kruskal-Wallis

Ao comparar-se a expressão de ET1 entre os grupos controle e COLVIM, observou-se maior expressão deste marcador nos animais COLV-IM aos 7, 75 e aos 210 dias após a primeira imunização, sendo que aos 210 dias a diferença foi significativa do ponto de vista estatístico $(p=0,040)$ (gráfico 4). Analisando-se comparativamente a expressão de ET1 ao longo do tempo, verifica-se que aos 210 dias ocorre queda nos níveis deste marcador nos animais controle, enquanto nos coelhos COL-IM nota-se um decréscimo aos 30 dias, seguido de um aumento progressivo a partir dos 75 dias. 
Gráfico 4 - Expressão de ET1 nas células endoteliais dérmicas de coelhos COLV-IM e dos controles

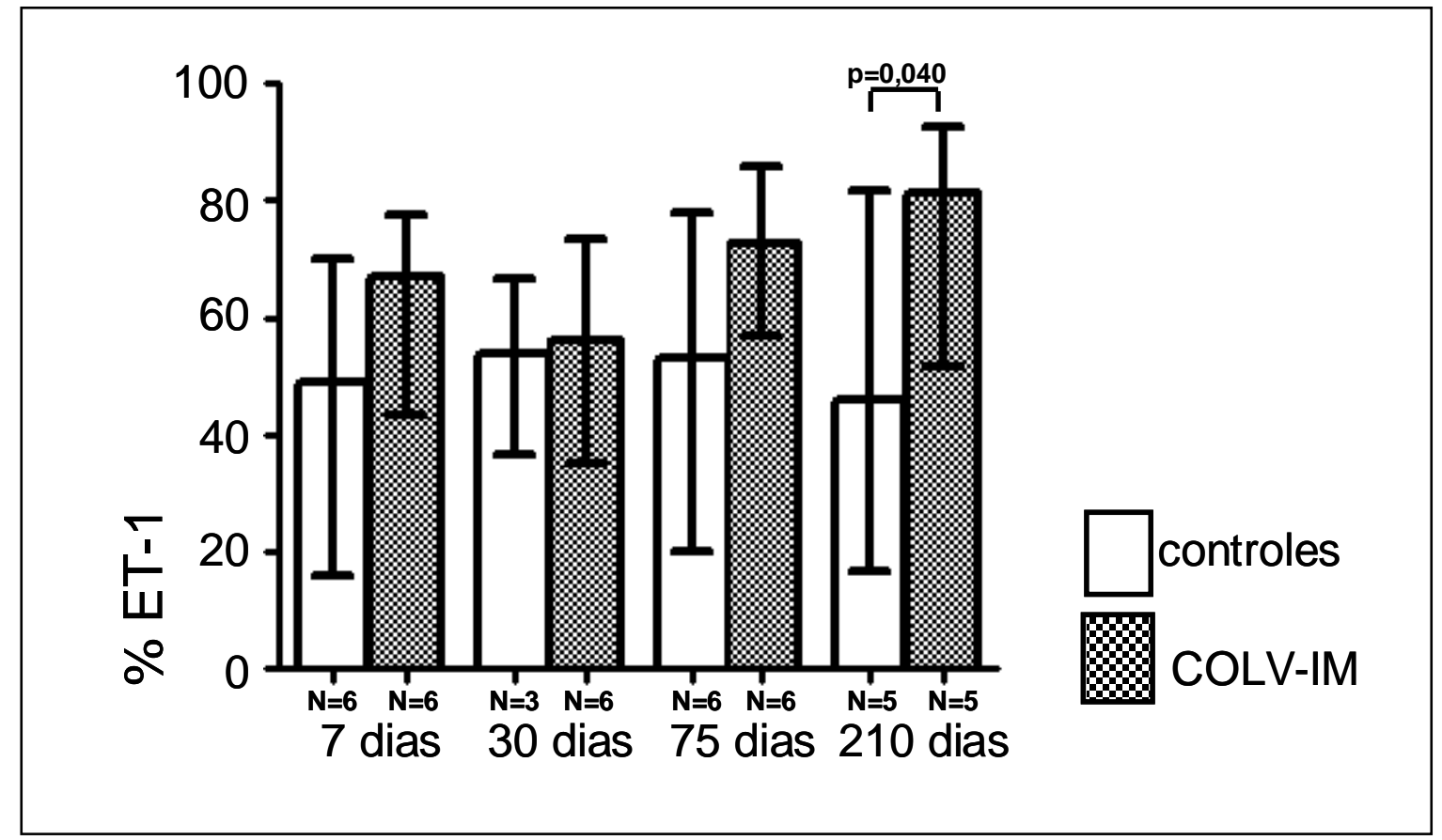

* as barras indicam as medianas e as retas o intervalo abrangendo os valores máximos e mínimos observados. Os grupos foram comparados por meio do teste de Kruskal-Wallis e posteriormente foram realizadas comparações múltiplas.

Em relação ao CTGF, quando os animais controles e os COLV-IM foram comparados, observou-se maior expressão deste marcador nas células endoteliais nos animais do grupo COLV-IM aos 7, aos 30 e aos 210 dias após a primeira imunização. Quando os animais do grupo COLV-IM foram comparados entre si, verificou-se que a quantidade de CTGF expressa nas células endoteliais aumenta aos 30 dias, mantém-se aos 75 dias e cai aos 210 dias após a imunização. Nos animais do grupo controle, o CTGF aumenta até os 75 dias e apresenta queda pronunciada aos 210 dias após a imunização (gráfico 5). Estas diferenças não foram significativas do ponto de vista estatístico. 
Gráfico 5 - Expressão de CTGF nas células endoteliais dérmicas de coelhos COLV-IM e dos controles

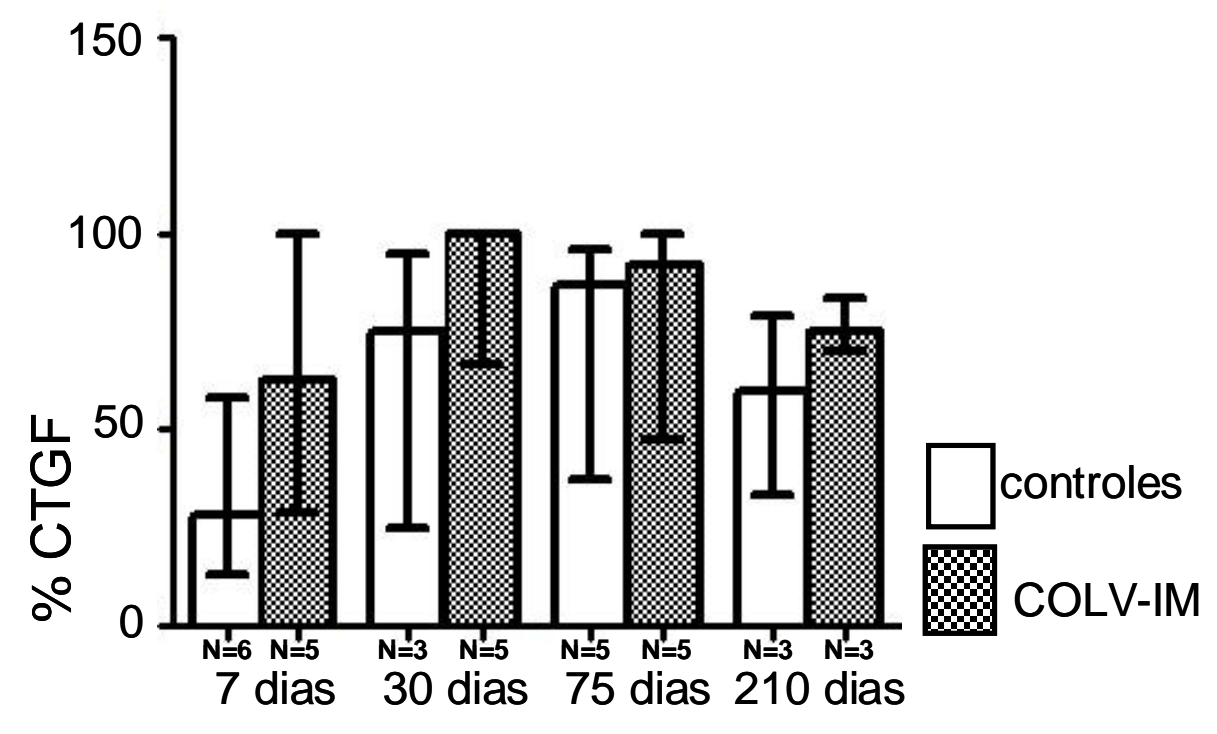

* as barras indicam as medianas e as retas o intervalo abrangendo os valores máximos e mínimos observados. Os grupos foram comparados por meio de ANOVA não paramétrica para medidas repetidas.

Já o TGF $\beta$ foi expresso de maneira similar pelas células endoteliais dos coelhos controle e do grupo COLV-IM, com ligeiro aumento de expressão aos 210 dias após a primeira imunização em ambos os grupos (gráfico 6), porém sem significância do ponto de vista estatístico.

Quanto ao VEGF, observou-se maior expressão deste marcador aos 7 dias após a primeira imunização nos animais COLV-IM, quando comparados aos controles no mesmo período. Novamente, este aumento não foi estatisticamente significativo. Aos 30 , aos 75 e aos 210 dias a expressão foi similar em ambos os grupos (gráfico 7). 
Gráfico 6 - Expressão de TGF $\beta$ nas células endoteliais dérmicas de coelhos COLV-IM e dos controles

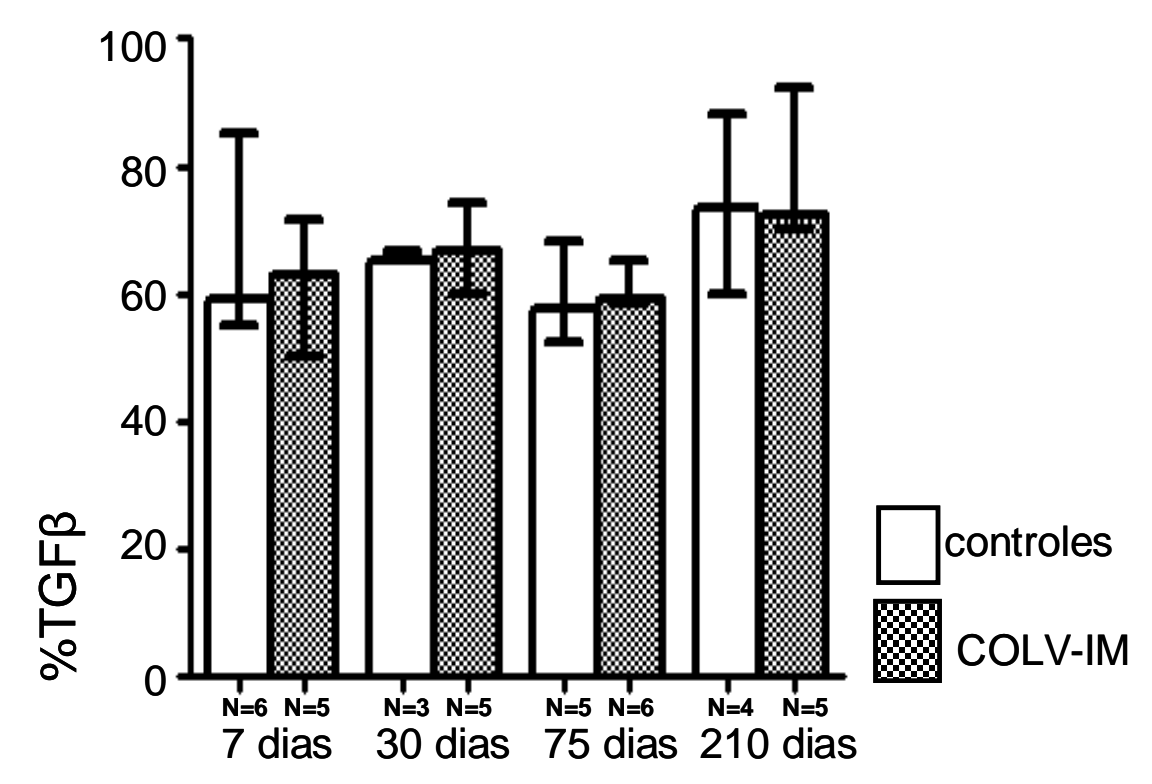

* as barras indicam as medianas e as retas o intervalo abrangendo os valores máximos e mínimos observados. Os grupos foram comparados por meio de ANOVA não paramétrica para medidas repetidas. 
Gráfico 7 - Expressão de VEGF nas células endoteliais dérmicas de coelhos COLV-IM e dos controles

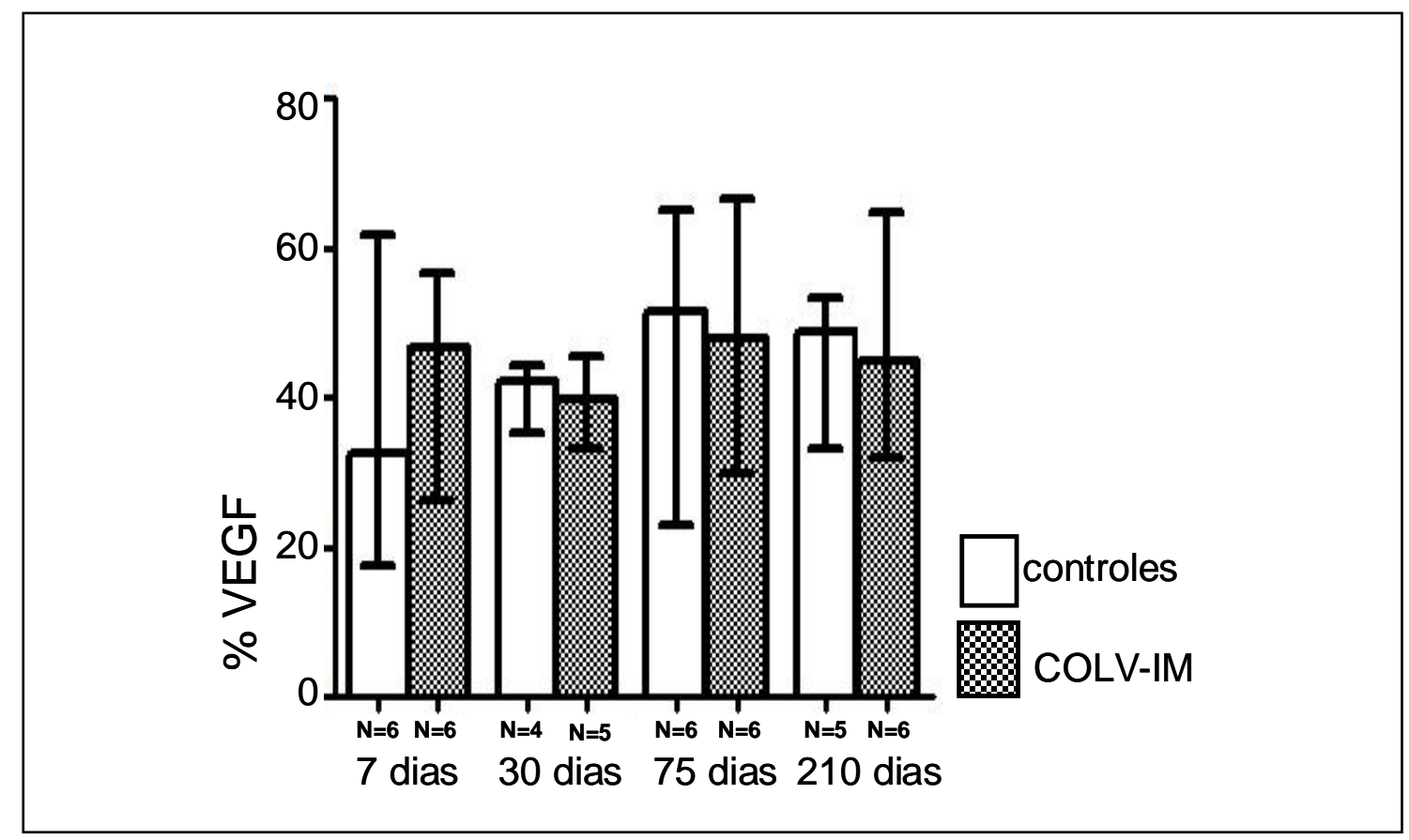

* as barras indicam as medianas e as retas o intervalo abrangendo os valores máximos e mínimos observados. Os grupos foram comparados por meio do teste de Kruskal-Wallis.

$\mathrm{Na}$ tabela 13, podem ser vistos os valores das medianas e o intervalo abrangendo os valores máximos e mínimos observados nos grupos de animais estudados para os diferentes marcadores. 
Tabela 13 - Expressão dos marcadores de apoptose e de ativação endotelial nas células endoteliais dérmicas de coelhos COLV-IM e de controles

\begin{tabular}{|c|c|c|c|c|c|}
\hline marcador & grupo & $\begin{array}{c}7 \text { dias } \\
\text { mediana } \\
\text { (intervalo) }\end{array}$ & $\begin{array}{c}30 \text { dias } \\
\text { mediana } \\
\text { (intervalo) }\end{array}$ & $\begin{array}{c}75 \text { dias } \\
\text { mediana } \\
\text { (intervalo) }\end{array}$ & $\begin{array}{l}210 \text { dias } \\
\text { mediana } \\
\text { (intervalo) }\end{array}$ \\
\hline \multirow[t]{2}{*}{ Caspase-3 } & controle & $\begin{array}{c}40,00 \\
(25,00-65,00)\end{array}$ & $\begin{array}{c}42,98 \\
(30,00-70,00)\end{array}$ & $\begin{array}{c}63,33 \\
(26,27-78,33)\end{array}$ & $\begin{array}{c}46,15 \\
(35,00-80,00)\end{array}$ \\
\hline & COLV-IM & $\begin{array}{c}64,64 \\
36,67-88,89\end{array}$ & $\begin{array}{c}27,78 \\
(18,06-73,67)\end{array}$ & $\begin{array}{c}42,92 \\
(13,33-64,04)\end{array}$ & $\begin{array}{c}52,50 \\
(35,71-91,67)\end{array}$ \\
\hline \multirow[t]{2}{*}{ ET1 } & controle & $\begin{array}{c}48,75 \\
(15,83-70,00)\end{array}$ & $\begin{array}{c}53,75 \\
(36,67-66,67)\end{array}$ & $\begin{array}{c}53,24 \\
(20,00-78,00)\end{array}$ & $\begin{array}{c}45,83 \\
(16,67-81,68)\end{array}$ \\
\hline & COLV-IM & $\begin{array}{c}67,08 \\
(43,33-77,67)\end{array}$ & $\begin{array}{c}55,94 \\
(35,00-73,33)\end{array}$ & $\begin{array}{c}72,50 \\
(56,67-85,83)\end{array}$ & $\begin{array}{c}81,33 \\
(51,67-92,50)\end{array}$ \\
\hline \multirow[t]{2}{*}{ CTGF } & controle & $\begin{array}{c}27,95 \\
(13,06-58,33)\end{array}$ & $\begin{array}{c}75,00 \\
(25,00-95,00)\end{array}$ & $\begin{array}{c}86,67 \\
(36,97-96,00)\end{array}$ & $\begin{array}{c}60,00 \\
(33,33-79,17)\end{array}$ \\
\hline & COLV-IM & $\begin{array}{c}62,50 \\
(28,57-100)\end{array}$ & $\begin{array}{c}100,00 \\
(66,67-100)\end{array}$ & $\begin{array}{c}92,00 \\
(47,22-100)\end{array}$ & $\begin{array}{c}75,00 \\
(70,00-83,3)\end{array}$ \\
\hline \multirow[t]{2}{*}{ TGF $\beta$} & controle & $\begin{array}{c}59,17 \\
(55,00-85,00)\end{array}$ & $\begin{array}{c}65,00 \\
(58,00-77,00)\end{array}$ & $\begin{array}{c}57,66 \\
(52,50-68,33)\end{array}$ & $\begin{array}{c}73,33 \\
(60,00-88,00)\end{array}$ \\
\hline & COLV-IM & $\begin{array}{c}63,00 \\
(50-71,66)\end{array}$ & $\begin{array}{c}66,00 \\
(60,00-74,00)\end{array}$ & $\begin{array}{c}59,16 \\
(58,33-65,00)\end{array}$ & $\begin{array}{c}72,22 \\
(71,36-92,17)\end{array}$ \\
\hline \multirow[t]{2}{*}{ VEGF } & controle & $\begin{array}{c}35,00 \\
(15,83-61,57)\end{array}$ & $\begin{array}{c}42,32 \\
(35,19-44,33)\end{array}$ & $\begin{array}{c}51,67(22,92- \\
65,00)\end{array}$ & $\begin{array}{c}50,00 \\
(33,33-60,83)\end{array}$ \\
\hline & COLV-IM & $\begin{array}{c}46,67 \\
(26,39-56,67)\end{array}$ & $\begin{array}{c}39,81 \\
(33,33-45,50)\end{array}$ & $\begin{array}{c}47,92 \\
(30,00-66,47)\end{array}$ & $\begin{array}{c}45,00 \\
(32,08-64,83)\end{array}$ \\
\hline
\end{tabular}


Estudos anteriores de nosso grupo mostraram que o COLV apresenta histoarquitetura fibrilar atípica tanto na pele como no tecido pulmonar de pacientes com ES (Bezerra, 2006; Parra, 2009). Estes achados não elucidavam se existia um aumento do COLV na pele, o quanto esta proteína poderia alterar a fibrilogênese e se poderia estar relacionada a outros mecanismos fisiopatogênicos da ES, como apoptose e ativação endotelial.

Neste estudo, demonstramos não apenas que há um grande aumento na deposição de COLV de morfologia anômala na derme de pacientes com ES, como também uma maior expressão desta proteína na doença precoce e sua associação com o grau de atividade da doença. Além disso, foi verificado que há correlação positiva entre a densidade de COLV e a expressão de marcadores de apoptose e de injúria endotelial na derme dos pacientes com ES. Adicionalmente, nos animais do modelo experimental de ES desenvolvido no nosso Laboratório, demonstrou-se que na derme de animais COLV-IM há maior expressão de COLV e de ET1.

Estes resultados indicam a existência de semelhanças entre o modelo experimental e a ES humana, fortalecendo a ideia de que as duas condições patológicas apresentem os mesmos mecanismos patogênicos no desenvolvimento do remodelamento matricial. Possivelmente, o COLV participe tanto da ativação e da apoptose das células endoteliais, como da composição anômala da histoarquitetura das fibras heterotípicas, justificando as mudanças nas propriedades fisiológicas e físicas da matriz extracelular dos órgãos 
acometidos nesta enfermidade.

A deposição excessiva de colágeno é a principal característica histopatológica da ES (Varga,2007). Dados da literatura registram uma maior deposição de COLIII (Fleischmajer, 1978) e de COLV (Liu, 2008) na derme de pacientes com critérios histopatológicos de doença precoce e de COLI nos estágios mais tardios da doença (Fleischmajer, 1978; Corriveau, 2009). Nossos dados confirmam aumento do COLV na fase precoce, porém adicionalmente demonstram que esta proteína encontra-se estruturalmente alterada. À medida que a doença avança para fases mais tardias, a quantidade de fibras de COLV diminui, enquanto as fibras de COLI aumentam, indicando que 0 remodelamento do colágeno é um processo dinâmico na $E S$, o que poderia explicar por que o espessamento cutâneo diminui espontaneamente ao longo do tempo (Wigley,2003).

Além do aumento do COLV, a presença de agregados anômalos desta proteína pode determinar desorganização da arquitetura habitual do tecido cutâneo, justificando o espessamento da pele observado na ES. Propomos de forma inédita que, na ES, não ocorre aumento da fibrose do tipo cicatricial fisiológica, mas um enovelamento atípico dos três tipos de colágenos que compõem a fibra heterotípica, causando remodelamento anormal do tecido conjuntivo nesta enfermidade. Neste sentido, é possível que as alterações sejam mais qualitativas que quantitativas, interferindo nas propriedades físicas dos tecidos.

De fato, a organização das fibras colágenas em lamelas ortogonais é 
imprescindível para garantir a transparência da córnea, assim como a distribuição em paralelo é necessária para conferir força e resistência aos tendões (Gelse,2003). Além disso, pacientes com a forma clássica da síndrome de Ehlers-Danlos, cujo fenótipo é caracterizado por pele fina, frágil e hiperextensível, apresentam fibras de COLV distribuídas de maneira esparsa e irregular no tecido cutâneo (Malfait, 2010).

A reconstrução tridimensional das fibras heterotípicas, provenientes da cultura de fibroblastos dérmicos de pacientes com ES, confirmou que as fibrilas de COLV apresentam arquitetura atípica, excluindo-se, assim, a interferência de fatores teciduais e humorais na formação de fibras heterotípicas aberrantes. Além disso, as fibras de COLI também estão espessadas, contribuindo para a desorganização tecidual e a mudança de textura da pele. Análises bioquímicas confirmaram esta alta expressão de COLV, especialmente da cadeia $\mathrm{COLVa}{ }_{2}$. Sabe-se que o COLV é uma importante molécula que regula o diâmetro das fibras heterotípicas, e que a sua modificação, qualitativa ou quantitativa, poderia interferir no processo da fibrilogênese (Chanut-Delalande, 2001; Wenstrup, 2004).

Ainda não sabemos a razão pela qual o COLV apresenta-se espessado e distorcido. Uma possível explicação seria a expressão desproporcionalmente maior do gene da cadeia $\mathrm{COLVa}_{2}$, resultando em síntese excessiva desta molécula (Parra, 2010). Além disso, mudanças pós-transcricionais, tais como hidroxilação da lisina, determinando aumento de pontes cruzadas entre moléculas do próprio COLV e defeitos na glicosilação, também poderiam 
justificar o espessamento e a perda da capacidade do COLV de controlar o diâmetro das fibras heterotípicas. De fato, pacientes com ES apresentam maior expressão gênica de lisil-hidroxilase (Brinckmann, 2005); e a presença de grande quantidade de resíduos de hidroxilisina glicosilados está associada a uma diminuição do diâmetro das fibrilas colágenas, tanto in vitro quanto in vivo (Birk, 1990; Brinckmann, 1999; Notbohm, 1999).

Conforme demonstrado no presente estudo, a expressão dos genes das cadeias COLVa $\alpha_{1}$ e COLVa $\alpha_{2}$ também está elevada na pele de pacientes com ES, corroborando com os dados histológicos. Nossa pesquisa está de acordo com estudos prévios que mostram maior expressão destes genes na pele e nos fibroblastos dérmicos de pacientes com ES (Pannu, 2006; Sargent, 2010). Um destes estudos identificou, por meio de microarray de cDNA, um perfil de expressão gênica associado à doença mais grave, caracterizada por maior MRSS e maior probabilidade de fibrose pulmonar. Dentre os genes responsáveis por estes perfis, encontram-se os genes das cadeias $\mathrm{COLVa}_{1} \mathrm{e}$ $\mathrm{COLVa}_{2}($ Sargent,2010).

Uma importante questão a ser respondida é a razão da excessiva síntese de COLV anômalo na pele de pacientes com ES, assim como nos animais do modelo experimental. A regulação da síntese desta proteína ocorre em nível transcricional, mediada pelo TGF $\beta$, que promove maior expressão dos genes das cadeias COLVa $\alpha_{1}$ e COLVa $\alpha_{2}$ na pele e na cultura de fibroblastos de pacientes com ES (Pannu, 2006; Sargent, 2010). Sabe-se que o TGF $\beta$ é um importante indutor da síntese de colágeno, mas para que a fibrose se perpetue, 
a presença de CTGF é fundamental (Moussad, 2000). Acredita-se que muitas das propriedades pró-fibróticas do TGF $\beta$ decorrem da sua capacidade de induzir a produção de CTGF, que, por sua vez, estimula a proliferação dos fibroblastos e a síntese de matriz extracelular (Grotendorst, 1997). Estes fatores de crescimento são sintetizados não apenas por fibroblastos, mas também por células endoteliais (Muenlich, 2007; Phan, 1991).

Apesar das evidências a favor de forte interação entre TGF $\beta$ e CTGF, vários estudos têm demonstrado que a ativação da transcrição dos genes do CTGF pode ocorrer independentemente do TGF $\beta$ (Dammeier, 1998; Murphy, 1999; Querfeld, 2000; Ricupero,1994; Riser, 2000; Samarin, 2010). Neste sentido, a hipóxia, condição presente nos tecidos dos pacientes com ES (Beyer, 2009), seria um importante indutor da síntese de CTGF pelas células endoteliais (Samarin, 2010). Além disso, a ET1(Rechia, 2009; Shi-Wen, 2004b) e as células endoteliais em apoptose via ativação da caspase-3 (Laplante, 2010) também induziriam a síntese deste fator de crescimento. Estes dados, aliados aos resultados do presente estudo - os quais demonstraram correlação positiva entre COLV e CTGF expresso nas células endoteliais, mas não entre este colágeno e o TGF $\beta$ expresso nestas células -, permitem postular que as células endoteliais também contribuam para a síntese excessiva de COLV. Sob regime de hipóxia e, possivelmente, sob influência de ET1 e caspase-3, estas células passariam a expressar CTGF, que, por sua vez, induziria à síntese desta proteína por fibroblastos presentes na derme dos pacientes com ES.

A presença de correlação entre a atividade de doença, avaliada por meio 
da escala de Valentini, que considera não apenas o espessamento cutâneo, mas também o acometimento vascular e pulmonar, o aumento de VHS e o consumo de complemento (Valentini, 2001; Valentini, 2003), sugere que o estudo morfométrico do COLV na derme poderia ser um importante instrumento para auxiliar na avaliação da atividade de doença. Porém, mais importante do que isso, a maior expressão de COLV nos pacientes com doença mais ativa sugere que, além de influenciar na biomecânica da pele, a expressão do COLV atípico poderia estar relacionada com a ocorrência de disfunções em diferentes órgãos.

De fato, a expressão aumentada de COLV anômalo não é um fenômeno restrito à pele de pacientes com a forma difusa ou limitada da doença. Nosso grupo demonstrou que pacientes com pneumopatia intersticial secundária à ES também apresentam depósito aumentado de fibras distorcidas de COLV nos septos alveolares e nas paredes das arteríolas pré-acinares. O aumento desta proteína está inversamente relacionado com a capacidade vital, a capacidade vital forçada, o volume expiratório forçado e a capacidade de difusão do monóxido de carbono (Parra, 2009). Estudos realizados na artéria pulmonar de animais com ES experimental (COLV-IM) demonstraram presença de importante espessamento da íntima vascular, com deposição de COLV atípico (dados não publicados). Estes resultados mostram que a presença de COLV anômalo é um achado comum, identificado em diferentes órgãos comprometidos pela doença, confirmando a relevância deste colágeno na patogênese da ES. 
Neste sentido, uma importante propriedade do COLV é a sua capacidade de induzir apoptose de células endoteliais, possivelmente pela ativação das caspases (Souza, 2010). Além disso, determinadas moléculas podem induzir lesão endotelial por diferentes mecanismos. Neste sentido, a interleucina -6 induz ativação e apoptose de células endoteliais em pacientes com ES (Barnes, 2010). Isso leva a acreditar que o COLV poderia agir da mesma forma, ou seja, além de induzir a apoptose, também poderia promover a ativação destas células.

De fato, no presente estudo foi demonstrada correlação positiva entre a expressão de caspase-3 e de ET1 pelas células endoteliais com a densidade de COLV na derme dos pacientes com ES. Ao se analisar os resultados obtidos no modelo animal de ES induzido pela imunização com COLV, pode-se sugerir que esta proteína esteja envolvida tanto na apoptose como na ativação das células endoteliais. Conforme observado nos gráficos 3 e 4, no $7^{\circ}$ dia após a primeira imunização com COLV, ocorre maior expressão de caspase-3 e de ET1 nas células endoteliais, sugerindo que fragmentos do COLV exógeno inoculados tenham induzido a apoptose e a ativação destas células. Aos 30 dias, ocorre diminuição destes fenômenos, provavelmente porque os fragmentos de COLV são neutralizados por anticorpos anti COLV, que são detectados no soro dos animais COLV-IM a partir do $30^{\circ}$ dia após a primeira imunização, levando à formação de imunocomplexos (Callado, 2007).

Estes imunocomplexos podem induzir lesão da camada endotelial e da membrana basal, causando exposição progressiva de COLV endógeno, 
encontrado normalmente oculto no interior das fibras heterotípicas na matriz extracelular. Aos 75 e 210 dias após a primeira imunização, não mais o COLV exógeno, mas sim o COLV endógeno exposto passaria a induzir novamente apoptose e ativação das células endoteliais (figura 16). Ainda de acordo com o gráfico 3, a imunização com adjuvante de Freund dos animais controles poderia também induzir apoptose progressiva destas células até 75 dias após a primeira imunização. Entretanto, aos 210 não há perpetuação do processo, diferente do que ocorre nos animais imunizados com COLV, quando a expressão de caspase-3 continua aumentada, indicando a persistência do processo apoptótico. 


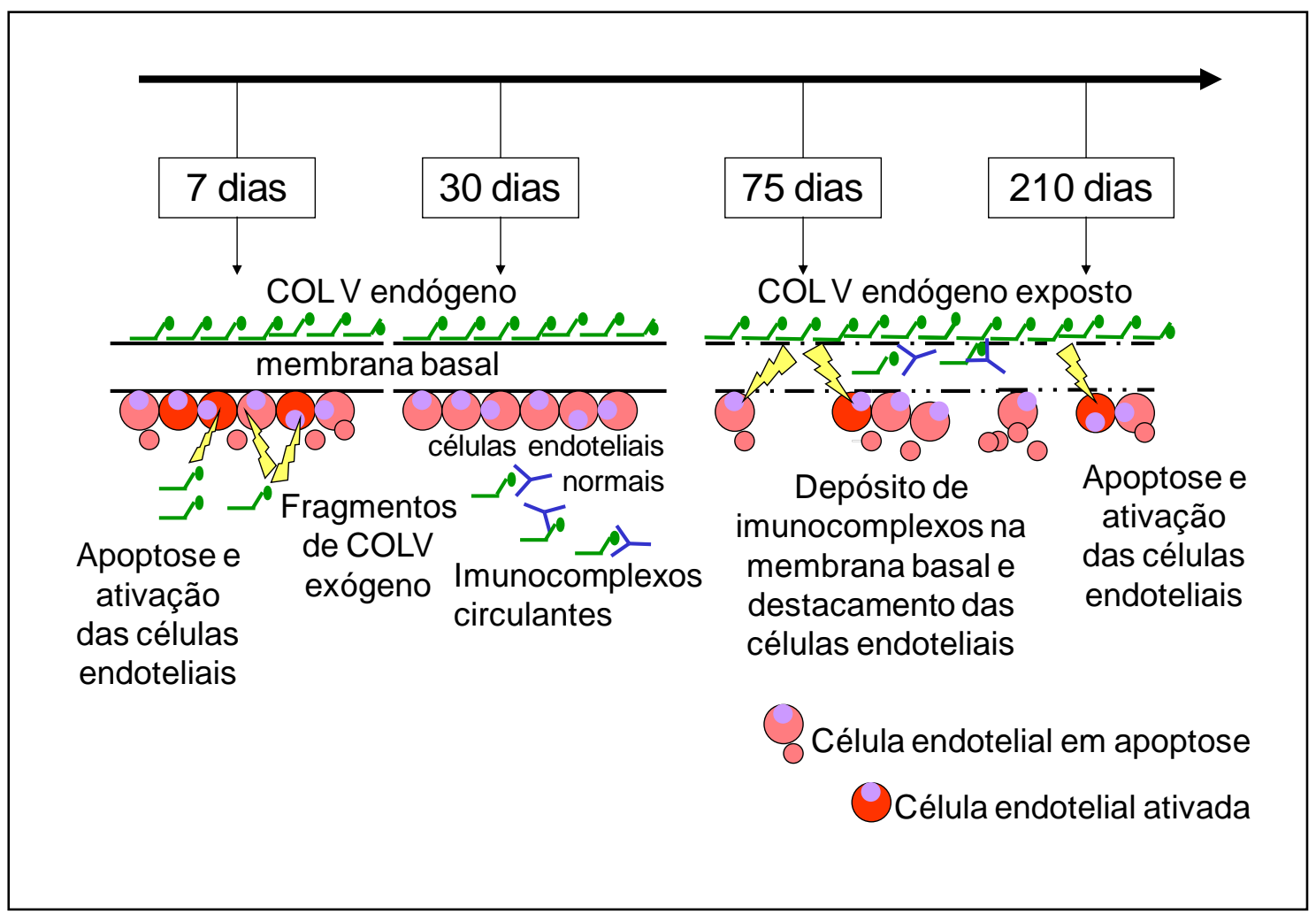

Figura 16 - apoptose e ativação das células endoteliais no modelo animal induzido pela imunização com COLV. Aos 7 dias após a primeira imunização, partículas de COL V causam injúria endotelial direta, levando à apoptose e à ativação das células endoteliais. Aos 30 dias, estas partículas são inativas devido à formação de imunocomplexos, que posteriormente se depositam na membrana basal, levando à exposição de COLV endógeno. Uma vez exposto, o COLV endógeno passa a induzir novamente apoptose e ativação destas células a partir do $75^{\circ}$ dia após a primeira imunização com COLV.

Estes dados são de enorme relevância na compreensão da etiopatogênese da ES. Consideramos que, no caso do modelo experimental de ES induzido por COLV, houve uma feliz coincidência ao se imunizar o animal com proteína exógena (COLV), encontrada habitualmente oculta e não exposta 
ao sistema imunológico. Outra incrível coincidência foi a de se descobrir posteriormente que esta molécula poderia induzir apoptose e ativação das células endoteliais.

Se, por um lado, o COLV poderia induzir apoptose e ativação das células endoteliais, por outro lado, sua expressão no tecido também poderia estar aumentada em consequência a estes eventos. Conforme pode ser observado no gráfico 2 e 3, no grupo COLV-IM aos 7 dias após a primeira imunização ocorre maior expressão tanto de COLV quanto de caspase-3, sendo que ambos diminuem aos 30 dias, voltando a aumentar aos 75 e aos 210 dias após a primeira imunização, sugerindo que a maior expressão de COLV possa estar relacionada ao aumento da apoptose das células endoteliais.

A literatura registra que mediadores produzidos por células endoteliais em apoptose têm a capacidade de regular a diferenciação dos fibroblastos. 0 sobrenadante do cultivo de células endoteliais oriundos de pacientes com ES promove aumento da produção de COLI pelos fibroblastos, de maneira independente do TGF $\beta$ (Laplante, 2010). Conforme o gráfico 6, a expressão de TGF $\beta$ nas células endoteliais foi semelhante nos grupos controle e COLV-IM, sugerindo que, de forma semelhante ao que foi observado na derme de pacientes com ES, a produção de COLV nos animais COLV-IM foi independente da produção desta citocina pelas células endoteliais.

Um possível mecanismo para explicar por que as células endoteliais em apoptose induzem o aumento da síntese de colágeno seria pela liberação de CTGF via ativação da caspase -3 (Laplante, 2010). Contudo, nos animais 
COLV-IM, parece não existir a ligação entre a expressão de caspase-3 e o CTGF, pois de acordo com os gráficos 3 e 5, a expressão de CTGF aumenta até os 30 dias após a primeira imunização nos coelhos, estabiliza-se aos 75 dias e diminui aos 210 dias; enquanto a expressão de caspase-3 diminui no $30^{\circ}$ dia no grupo COLV-IM. Entretanto, outros fatores poderiam resultar na maior expressão de CTGF neste estágio, prejudicando a interpretação dos resultados. Neste sentido, é possível que imunocomplexos circulantes, presentes no soro dos animais COLV-IM a partir do $30^{\circ}$ dia, também possam induzir a expressão de CTGF pelas células endoteliais (Callado, 2005).

Por outro lado, a expressão aumentada de COLV também poderia resultar da ação da ET1. A expressão de COLV e de ET1 tem distribuição similar ao longo do tempo nos animais COLV-IM e o tratamento de fibroblastos pulmonares normais com ET1 resulta em maior expressão da cadeia COLVa ${ }_{1}$ (Shi Wen, 2004b).

Nem todos os resultados discutidos acima apresentaram significância do ponto de vista estatístico, possivelmente devido ao número de casos estudados. Entretanto, apesar de especulativos, são muito importantes, pois sugerem que as células endoteliais em apoptose ou ativadas poderiam estimular a síntese de COLV e que, por outro lado, o próprio COLV poderia induzir apoptose, assim como ativar estas células, perpetuando a injúria endotelial. Estudos in vitro poderiam esclarecer se a apoptose e a ativação endotelial são causas ou consequências da expressão aumentada de COLV 
anômalo ou, ainda, se ambos os mecanismos ocorrem simultaneamente.

Há maior expressão de VEGF na derme de pacientes com ES (Davies, 2006; Distler 2004; Mackiewicz, 2002); um estudo demonstrou que a expressão aumentada deste marcador em diferentes células dérmicas ocorre tanto em pacientes com doença precoce quanto naqueles com doença tardia (Distler, 2004). Entretanto, no presente estudo, observou-se que as células endoteliais dérmicas de pacientes com doença tardia apresentam maior quantidade de VEGF. Não houve correlação entre o COLV depositado na derme e o VEGF presente nas células endoteliais de pacientes com ES, sugerindo que o COLV não induz a expressão deste marcador. Por outro lado, embora de maneira não significativa, animais COLV-IM apresentaram maior expressão deste fator de crescimento no $7^{\circ}$ dia após a primeira imunização, quando comparados aos controles, o que não se mantém com o decorrer do tempo. Desta forma, são necessários estudos in vitro para elucidar se este colágeno poderia induzir a expressão de VEGF nas células endoteliais, contribuindo para a angiogênese defeituosa.

O presente estudo tem grande importância na compreensão da fisiopatologia da ES, pois, pela primeira vez, demonstrou-se a relevância de um modelo experimental que reproduz alterações morfológicas e imunológicas encontradas na enfermidade humana. Aspecto comum às duas condições patológicas foi o encontro de COLV anômalo em todos os órgãos acometidos pela enfermidade, e que justifica a ocorrência dos três aspectos básicos observados na ES, ou seja, remodelamento matricial, autoimunidade e 
vasculopatia.

Acreditamos que a imunização do coelho com COLV tenha promovido remodelamento precoce matricial devido à indução de apoptose e à ativação das células endoteliais, à formação de imunocomplexos (COLV-antiCOLV), ao depósito destes imunocomplexos na camada endotelial, com consequente lesão do complexo endotélio-membrana basal, permitindo o influxo de células inflamatórias para o interior da matriz extracelular. Enzimas proteolíticas liberadas pelas células inflamatórias teriam ocasionado ruptura das fibras heterotípicas e exposição de COLV oculto, o qual passou a se comportar como autoantígeno. Lembramos que este autoantígeno, na presença de anti COLV circulante, fruto da imunização previa do animal, tenha contribuído para a manutenção da formação de imunecomplexos, além de perpetuar o dano matricial e de manter ativo o sistema imunológico por meio da produção de anticorpos anti-COLV. Adicionalmente, o próprio COLV endógeno poderia atuar como agente indutor de apoptose e de ativação das células endoteliais, contribuindo na perpetuação do dano vascular.

Baseados nos dados apresentados, postulamos uma nova visão em relação à ES. Trata-se de enfermidade possivelmente adquirida, desencadeada em indivíduo geneticamente predisposto, causada por fatores externos, como substâncias exógenas tóxicas e/ou infecções prolongadas, as quais determinam lesão do complexo endotélio/epitélio/membrana basal, promovendo a exposição de autoantígenos previamente ocultos, em especial do COLV. O neoantígeno passa a ativar o sistema imunológico via padrão Th2, originando autoanticorpos 
e remodelamento matricial de modo contínuo. A fibrilogênese é defeituosa devido à excessiva síntese de COLV de características estruturais atípicas. Adicionalmente, o COLV tem propriedades pró-apoptóticas e de ativação das células endoteliais, ativando a síntese de mediadores responsáveis pela manutenção das alterações observadas na fibrilogênese (figura 17). 


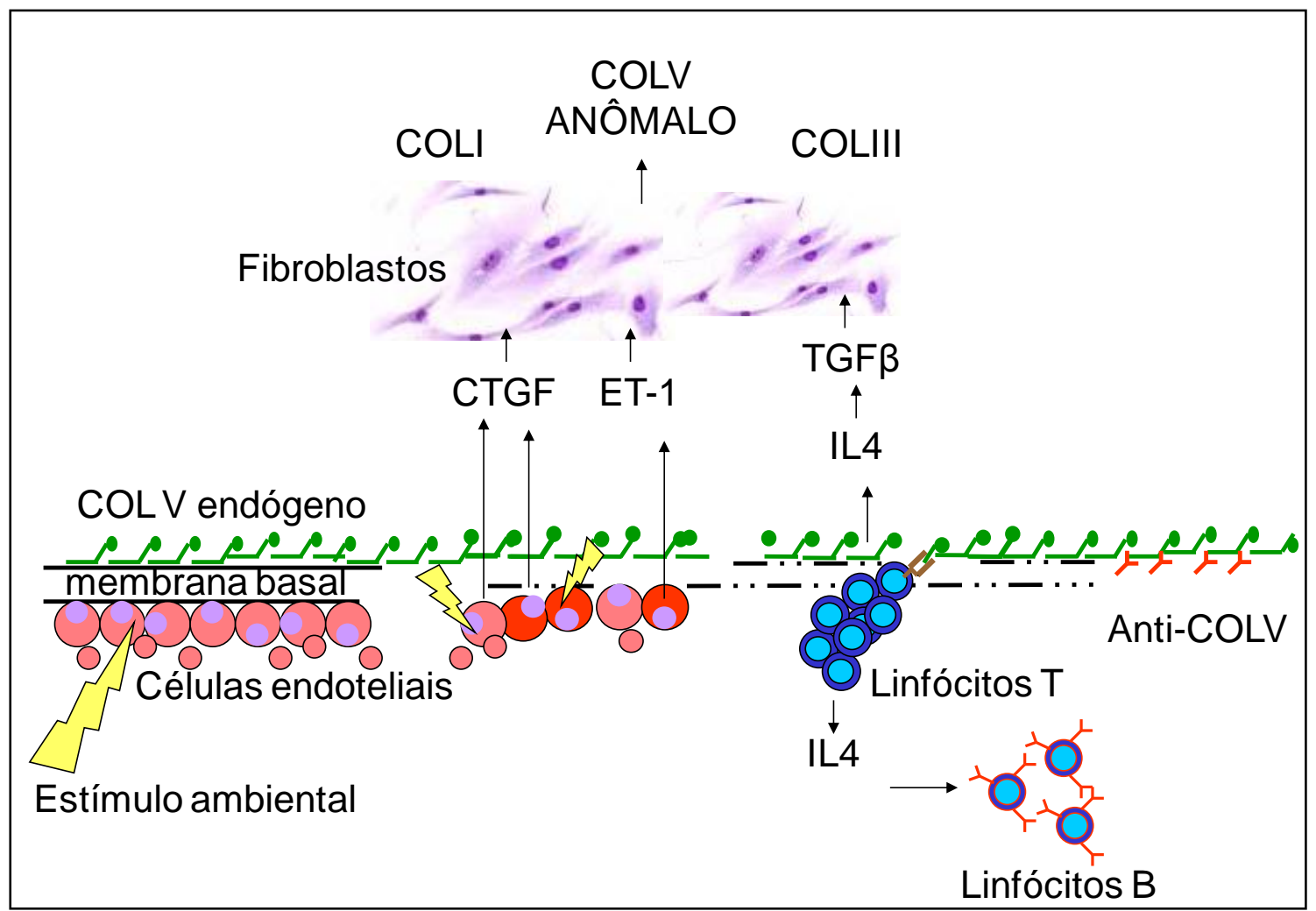

Figura 17- mecanismo proposto para a patogênese da ES. Em indivíduos geneticamente predispostos, agentes ambientais causariam lesão endotelial, levando a destacamento das células endoteliais e a interrupção da membrana basal com exposição de COLV previamente oculto no interior das fibras heterotípicas. Os linfócitos T reconheceriam o COLV como um neoantígeno, desencadeando resposta do tipo Th2 com liberação de IL4, que, por sua vez, induziria a produção de TGF $\beta$, resultando na síntese excessiva de colágeno, inclusive COLV atípico que levaria à fibrilogênese defeituosa. Além disso, a IL4 estimularia os linfócitos B e a produção de autoanticorpos. Adicionalmente, o COLV causaria apoptose e ativação das células endoteliais, com consequente produção de CTGF e ET1, que também aumetam a síntese de colágeno contribuindo para a manutenção do processo fibrótico. 
6 CONCLUSÕES 
- O COLV é encontrado morfologicamente anômalo na derme de pacientes com ES; sua expressão está aumentada, principalmente na doença precoce, e correlaciona-se inversamente com o tempo de duração da doença.

- A expressão do COLV está associada ao grau de atividade da ES.

- O COLI está aumentado nos pacientes com doença tardia e correlaciona-se diretamente com o tempo de duração da doença; o COLIII está aumentado nos pacientes com doença precoce.

- Há correlação positiva entre a deposição de COLV na derme de pacientes com ES e a expressão de caspase-3, de ET1 e de CTGF nas células endoteliais dérmicas.

- Nos animais do modelo experimental de ES induzida pela imunização com COLV, observa-se aumento significativo da expressão de COLV, precocemente, na derme dos animais aos 7 dias e de ET1 nas células endoteliais aos 210 dias após a primeira imunização, quando comparados aos animais controle. 


\section{ANEXOS}


Anexo A: Termo de Consetimento Livre e Esclarecido

\section{HOSPITAL DAS CLÍNICAS}

DA

FACULDADE DE MEDICINA DA UNIVERSIDADE DE SÃO PAULO

TERMO DE CONSENTIMENTO LIVRE E ESCLARECIDO

\section{I - DADOS DE IDENTIFICAÇÃO DO SUJEITO DA PESQUISA OU RESPONSÁVEL LEGAL}

1. NOME DO PACIENTE :

DOCUMENTO DE IDENTIDADE $\mathrm{N}^{\circ}$ : SEXO : .M Z F Ž

DATA NASCIMENTO:

ENDEREÇO

BAIRRO:

CEP:

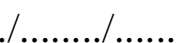

............. $\mathrm{N}^{\mathrm{o}}$

CIDADE .TELEFONE:

APTO:

\section{II - DADOS SOBRE A PESQUISA CIENTÍFICA}

1- TÍTULO DO PROTOCOLO DE PESQUISA: Estudo Comparativo da Interação Endotélio Matriz Extracelular no remodelamento da Pele Observada no Modelo Experimental de Esclerodermia e na Enfermidade Espontânea Humana.

2- PESQUISADOR: Patrícia Martin

3- CARGO/FUNÇÃO: médica INSCRIÇÃO CONSELHO REGIONAL : 114786

UNIDADE DO HCFMUSP: reumatologia

4- AVALIAÇÃO DO RISCO DA PESQUISA: risco baixo

(probabilidade de que o indivíduo sofra algum dano como consequência imediata ou tardia do estudo)

5- DURAÇÃO DA PESQUISA : 4 anos 


\section{III - REGISTRO DAS EXPLICAÇÕES DO PESQUISADOR AO PACIENTE OU SEU REPRESENTANTE LEGAL SOBRE A PESQUISA, CONSIGNANDO:}

Ainda não sabemos a causa da esclerose sistêmica, mas estamos pesquisando algumas alternativas em nosso laboratório, pois conhecendo a causa poderemos desenvolver medicamentos mais eficazes. Para isto precisamos analisar no microscópio dois pedaços pequenos (ou biópsias) de sua pele: um de pele doente e um de pele boa. Antes da biópsia você responderá algumas perguntas e será examinado.

A biópsia será realizada por um médico, com anestesia local e terá o tamanho de aproximadamente $4 \mathrm{~mm}$. Você somente sentirá uma leve queimação da anestesia local e 1 ou 2 pontos serão necessários para a cicatrização da biópsia, que após 10 dias serão retirados. A região da biópsia poderá formar um pequena cicatriz que com o tempo geralmente retorna ao aspecto normal.

Você irá beneficiar todas as pessoas que tem esclerose sistêmica como você, pois os resultados deste e de futuros estudos ajudarão a descobrir a causa e melhorar ainda mais o tratamento de sua doença. Você poderá desistir desta pesquisa a qualquer momento e seu tratamento não será prejudicado.

\section{IV - ESCLARECIMENTOS DADOS PELO PESQUISADOR SOBRE GARANTIAS DO SUJEITO DA PESQUISA:}

Em caso de algum problema após a biópsia você será atendido pela Dra Patrícia Martin através da Disciplina de Reumatologia.

\section{INFORMAÇÕES DE NOMES, ENDEREÇOS E TELEFONES DOS RESPONSÁVEIS PELO ACOMPANHAMENTO DA PESQUISA, PARA CONTATO EM CASO DE INTERCORRÊNCIAS CLÍNICAS E REAÇÕES ADVERSAS}

Dra Patrícia Martin - fone 9112-0249

Ambulatório de Esclerose Sistêmica - Segunda feira de manhã ( das 8:00 às 11:00)

Rua Enéas de Carvalho Aguiar, Prédio dos Ambulatórios, sala 4B 5 andar 


\section{VII - CONSENTIMENTO PÓS-ESCLARECIDO}

Declaro que, após convenientemente esclarecido pelo pesquisador e ter entendido o que me foi explicado, consinto em participar do presente Protocolo de Pesquisa

São Paulo, de de

assinatura do sujeito da pesquisa ou responsável legal:

assinatura do pesquisador:

(carimbo ou nome Legível)

\section{INSTRUÇÕES PARA PREENCHIMENTO (Resolução Conselho Nacional de Saúde 196, de 10 outubro 1996)}

1. Este termo conterá o registro das informações que o pesquisador fornecerá ao sujeito da pesquisa, em linguagem clara e accessível, evitando-se vocábulos técnicos não compatíveis com o grau de conhecimento do interlocutor.

2. A avaliação do grau de risco deve ser minuciosa, levando em conta qualquer possibilidade de intervenção e de dano à integridade física do sujeito da pesquisa.

3. O formulário poderá ser preenchido em letra de forma legível, datilografia ou meios eletrônicos.

4. Este termo deverá ser elaborado em duas vias, ficando uma via em poder do paciente ou seu representante legal e outra deverá ser juntada ao prontuário do paciente.

5. A via do Termo de Consentimento Pós-Informação submetida à análise da Comissão de Ética para Análise de Projetos de Pesquisa -CAPPesq deverá ser idêntica àquela que será fornecida ao sujeito da pesquisa. 
Anexo B. Aprovação da CAPPesq

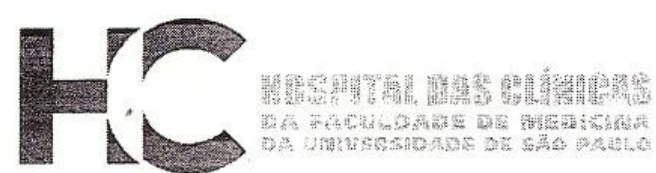

\section{APROVAÇÃO}

A Comissão de Ética para Análise de Projetos de Pesquisa - CAPPesq da Diretoria Clínica do Hospital das Clínicas e da Faculdade de Medicina da Universidade de São Paulo, em sessão de 03/10/2007, APROVOU o Protocolo de Pesquisa $n^{\circ}$ 0817/07, intitulado: "ESTUDO COMPARATIVO DA INTERAÇĀO ENDOTÉLIO - MATRIZ EXTRACELULAR NO REMODELAMENTO DE PELE, OBSERVADA NO MODELO EXPERIMENTAL DE ESCLERODERMIA E NA ENFERMIDADE ESPONTÂNEA HUMANA." apresentado pelo Departamento de CLÍNICA MÉDICA.

Cabe ao pesquisador elaborar e apresentar à CAPPesq, os relatórios parciais e final sobre a pesquisa (Resolução do Conselho Nacional de Saúde $n^{\circ}$ 196, de 10/10/1996, inciso IX.2, letra "c").

Pesquisador (a) Responsável: PROF. DR. NATALINO HAJIME YOSHINARI Pesquisador (a) Executante: PATRíCIA MARTIN

CAPPesq, 05 de Outubro de 2007

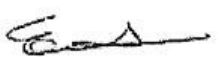

Prof. Dr. Eduardo Massad Presidente da Comissão de Ética para Análise de Projetos de Pesquisa 


\section{REFERÊNCIAS}


Abraham D, Distler O. How does endothelial cell injury start? The role of endothelin in systemic sclerosis. Arthritis Res Ther. 2007; 9(Suppl 2):1-8.

Alberts, B, Johnson A, Lewis J, Raff M, Roberts K, Walter P. Biologia Molecular da Célula. 5a ed. São Paulo: Artmed; 2010. cap19.1131-1204. Junçoes Extracelulares, Adesão Celular e Matriz Extracelular

Al-Dhaher FF, Pope JE, Ouimet JM. Determinants of morbidity and mortality of systemic sclerosis in Canada. Semin Arthritis Rheum. 2010;39:269-77.

Allanore Y, Wipff J, Kahan A, Boileau C. Genetic basis for systemic sclerosis. Joint Bone Spine. 2007;74:577-83.

Arnett FC, Gourh P, Shete S, Ahn CW, Honey R, Agarwal SK, et al. Major Histocompatibility Complex (MHC) class II alleles, haplotypes, and epitopes which confer susceptibility or protection in the fibrosing autoimmune disease systemic sclerosis: analyses in 1300 Caucasian, African-American and Hispanic cases and 1000 controls. Ann Rheum Dis. 2010;69:822-7.

Avouac J, Wipff J, Goldman O, Ruiz B, Couraud PO, Chiocchia G, et al. Angiogenesis in systemic sclerosis: impaired expression of vascular endothelial growth factor receptor 1 in endothelial progenitor-derived cells under hypoxic conditions. Arthritis Rheum. 2008;58:3550-61.

Barnes TC, Spiller DG, Anderson ME, Edwards SW, Moots RJ. Endothelial activation and apoptosis mediated by neutrophil-dependent interleukin 6 transsignalling: a novel target for systemic sclerosis? Ann Rheum Dis. 2011 70:36672. 
Baroni SS, Santillo M, Bevilacqua F, Luchetti M, Spadoni T, Mancini M, et al. Stimulatory autoantibodies to the PDGF receptor in systemic sclerosis. $N$ Engl $J$ Med. 2006 ;354:2667-76.

Behr J, Furst DE. Pulmonary function tests. Rheumatology. 2008;47:v65-v67.

Belotti Masserini A, Zeni S, Cossutta R, Soldi A, Fantini F. Analisi dei costi nella sclerosi sistemica. Studio retrospettivo in una casistica di 106 pazienti/Cost-ofillness in systemic sclerosis: a retrospective 40 study of an Italian cohort of 106 patients. Reumatismo. 2003;55:245-55.

Bernatsky S, Hudson M, Panopalis P et al. The cost of systemic sclerosis. Arthritis Rheum. 2009;61:119-23.

Beyer C, Schett G, Gay S, Distler O, Distler JH. Hypoxia. Hypoxia in the pathogenesis of systemic sclerosis. Arthritis Res Ther. 2009;11:220.

Bezerra MC, Teodoro WR, de Oliveira CC, Velosa APP, Ogido LT, Gauditano T, Parra ER, Capelozzi VL, Yoshinari NH. Scleroderma like remodeling induced by type V collagen. Arch Dermatol Res. 2006; 298:51-7.

Bharat A, Fields RC, Steward N, Trulock EP, Patterson GA, Mohanakumar T. Am J Transplant. 2006 Aug;6(8):1799-808. CD4+25+ regulatory T cells limit Th1-autoimmunity by inducing IL-10 producing $T$ cells following human lung transplantation. Am J Transplant. 2006;6:1799-808.

Birk DE. Type $\mathrm{V}$ collagen. Heterotipic type $\mathrm{I} / \mathrm{V}$ collagen interactions in the regulation of fibril assembly. Micron. 2001;32:223-37. 
Birk DE, Fitch JM, Babiarz JP, Doane KJ, Linsenmayer TF. Collagen fibrillogenesis in vitro: interaction of types $\mathrm{I}$ and $\mathrm{V}$ collagen regulates fibril diameter. J Cell Science. 1990;95:649-657.

Blobe GC, Schiemann WP, Lodish HF. Role of transforming growth factor beta in human disease. N Engl J Med. 2000;342:1350-8.

Bombeli T, Schwartz BR, Harlan JM. Endothelial cells undergoing apoptosis become proadhesive for nonactivated platelets. Blood. 1999; 93:3831-8

Bordron A, Dueymes M, Levy Y, Jamia C, LeRoy JP, Piette JC. The binding of some human antiendothelial cell antibodies induces endothelial cell apoptosis. J Clin Invest. 1996;2029 -36.

Brinckmann J, Kim S, Wu J, Reinhardt DP, Batmunkh C, Metzen E, et al. Interleukin 4 and prolonged hypoxia induce a higher gene expression of lysil hidroxylase 2 and an altered cross link pattern: important pathogenetic steps in early and late stage of systemic scleroderma. Matrix Biol. 2005;24:459-68.

Brinckmann J, Notbohm H, Tronnier M, Acil Y, Fietzek P P, Schneller W, et al. Overhydroxylation of lysyl residues is the initial step for altered collagen crosslink and fibril architecture in fibrotic skin. J. Invest. Dermatol. 1999;113:617-21.

Brunner E, Langer, F. Nonparametric analysis of ordered categorical data in designs with longitudinal observations and small sample sizes. Biometrical Journal, 2000;42:663-675.

Burlingham WJ, Love RB, Jankowska-Gan E, et al. IL-17-dependent cellular immunity to collagen type $\mathrm{V}$ predisposes to obliterative bronchiolitis in human lung transplants. J Clin Invest. 2007;117:3498-506. 
Callado, Maria Roseli Monteiro. Caracterização da resposta imune em modelo experimental de esclerodermia induzido por colágeno $V$ [tese]. São Paulo: Faculdade de Medicina da Universidade de São Paulo, 2005

Callado MR, Viana VS, Vendramini MB, Leon EP, Bueno C, Velosa AP, Teodoro WR, Yoshinari NH. Autoantibody profile in the experimental model of scleroderma induced by type $\mathrm{V}$ human collagen. Immunology. 2007;122:38-46.

Callewaert B, Malfait F, Loeys B, De Paepe A. Ehlers-Danlos syndromes and Marfan syndrome. Best Pract Res Clin Rheumatol. 2008;22:165-89.

Carvalho D, Savage SO, Black, CM, Pearso JD. IgG antiendothelial cells antibodies from scleroderma patients induce leukocite adhesion to human vascular endothelial cells in vitro. Induction of adhesion molecule expression and involvement of endothelial derived citokines. J Clin Invest. 1996; 97:111-9.

Cassinotti P, Burtonboy G, Fopp M, Siegl G. Evidence for persistence of human parvovirus B19 DNA in bone marrow. J Med Virol. 1997;53:229-32.

Chanut-Delalande H, Bonod-Bidaud C, Cogne S, Malbouyres M, Ramirez F, Fichard A, et al. Development of a functional skin matrix requires deposition of collagen V heterotrimers. Mol and Cell Biology. 2001; 24:6049-57.

Clements PJ, Hurwitz EL, Wong WK. Skin thickness score as a predictor and correlate of outcome in systemic sclerosis. Arthritis and Rheum. 2000;43: 244552.

Clements PJ, Lachenbruch P, Siebold. Inter and Intraobsever variability of total skin thickness score (modified Rodnan TSS) in systemic sclerosis. $J$ Rheumatol. 1995;22:1281-5. 
Coelho JC, Giugliane R. Fibroblasts of skin fragments as a tool for the investigation of genetic diseases: technical recommendations. Genet. Mol. Biol. 2000;23:269-71.

Corriveau MP, Noufaied I, Lessard J. The fibrotic phenotype of systemic sclerosis fibroblasts varies with disease duration and severity of skin involvement: reconstruction of skin fibrosis development using a tissue engineering aproach. J Pathol 2009; 217:534-42.

Cotton SA, Herrick AL, Jaysson MIV, Freemont A. Endothelial expression of nitric oxide synthases and nitrotyrosin in systemic sclerosis skin. J Pathol. 1999;189:273-8.

Czirják L, Kumánovics G, Varjú C, Nagy Z, Pákozdi A, Szekanecz Z, et al. Survival and causes of death in 366 Hungarian patients with systemic sclerosis. Ann Rheum Dis. 2008;67:59-63.

D'Alessio S, Fibbi G, Cinelli M et al. Matrix metalloproteinase12-dependent cleavage of urokinase receptor in systemic sclerosis microvascular endothelial cells results in impaired angiogenesis. Arthritis Rheum. 2004;50:3275-85.

Dammeier J, Beer HD, Brauchle M, Werner S. Dexamethasone is a novel potent inducer of connective tissue growth factor expression: Implications for glucocorticoid therapy. J Biol Chem. 1998; 273:18185-18190.

Davies CA, Jeziorska M, Freemont AJ, Herrick AL. The differential expression of VEGF, VEGFR-2, and GLUT-1 proteins in disease subtypes of systemic sclerosis. Hum Pathol. $2006 ; 37: 190-7$ 
de Oliveira CC, Velosa APP, Parra ER, Capelozzi VL, Teodoro WR, Yoshinari $\mathrm{NH}$. Histomorphometric analysis of cutaneous remodeling in the early stage of the scleroderma model. Clinics. 2009;64:577-83.

Del RA, Distler O, Milia AF, Emanueli C, Ibba-Manneschi L, Guiducci S et al. Increased circulating levels of tissue kallikrein in systemic sclerosis correlate with microvascular involvement. Ann Rheum Dis. 2005;64:382-7.

Denton CP, Bickerstaff MC, Shiwen X, Carulli MT, Haskard DO, Dubois RM, et al. Serial circulating adhesion molecule levels reflect disease severity in systemic sclerosis. Br J Rheumatol. 1995; 34:1048-54.

Dieude P, Dawidowicz K, Guedj M, Legrain Y, Wipff J, Hachulla E, et al. Phenotypehaplotype correlation of IRF5 in Systemic Sclerosis: Role of two haplotype in disease severity. J Rheumatol. 2010;37:987-92.

Dieude P, Guedj M, Wipff J, Avouac J, Fajardy I, Diot E, et al. Association between the IRF5 rs2004640 functional polymorphism and systemic sclerosis: a new perspective for pulmonary fibrosis. Arthritis Rheum.2009a;60:225-33.

Dieude P, Guedj M, Wipff J, Avouac J, Hachulla E, Diot E, et al. The PTPN22 620W allele confers susceptibility to systemic sclerosis: findings of a large case-control study of European Caucasians and a meta-analysis. Arthritis Rheum. 2008;58:2183-8.

Dieude P, Guedj M, Wipff J, Ruiz B, Hachulla E, Diot E, et al. STAT4 is a genetic risk factor for systemic sclerosis having additive effects with IRF5 on disease susceptibility and related pulmonary fibrosis. Arthritis Rheum. 2009b;60:2472-9. 
Dieude P, Wipff J, Guedj M, Ruiz B, Melchers I, Hachulla E, et al. BANK1 is a genetic risk factor for diffuse cutaneous systemic sclerosis and has additive effects with IRF5 and STAT4. Arthritis Rheum. 2009c;60: 3447-54.

Distler O, Del Rosso A, GiacomelR, CirpianiP, Conforti ML, Guiducci S, et al. Angiogenic and angiostatic factores in systemic sclerosis: increased levels of vascular endothelial growth factor are a feature of the earliest disease stages and are associated with absence of fingertip ulcers. Arthrits Res. 2002; 4:R11.

Distler O, Distler JH, Scheid A, Acker T, Hirth A, Rethage J et al. Uncontrolled expression of vascular endothelial growth factor and its receptors leads to insufficient skin angiogenesis in patients with systemic sclerosis. Circ Res. 2004; 95:109-16.

Dor Y, Djonov V, Abramovitch R, Itin A, Fishman GI, Carmeliet P, et al. Conditional switching of VEGF provides new insights into adult neovascularization and pro-angiogenic therapy. EMBO J. 2002; 21:1939-47.

Feghali Bostwick C, Medsger TA Jr, Wright TM. Analysis of systemic sclerosis in twins reveals low concordance for disease and high concordance for the presence of antinuclear antibodies. Arthritis Rheum. 2003;48:1956-63.

Ferri C, Valentini G, Cozzi F, Sebastiani M, Michelassi C, La Montagna G, et al. Systemic sclerosis: demographic, clinical, and serologic features and survival in 1,012 Italian patients. Medicine (Baltimore). 2002;81:139-53.

Ferri C, Zakrzewska K, Longombardo G, et al. Parvovirus B19 infection of bone marrow in systemic sclerosis patients. Clin Exp Rheumatol.1999;17:718-20.

Fleischmajer R, Gay S, Meigel WN, Perlish J. Collagen in the cellular and fibrotic stages of scleroderma. Arthritis Rheum 1978; 21:418-427. 
Fleming JN, Schwartz SM. The pathology of scleroderma vascular disease. Rheum Dis Clin N Am. 2008(34):41-55.

Frazier K, Williams S, Kothapalli D, Klapper H, Grotendorst GR. Stimulation of fibroblast cell growth, matrix production, and granulation tissue formation by connective tissue growth factor. J Invest Dermatol. 1996;107:404-11.

Fukami N, Ramachandran S, Saini D, et al. Antibodies to MHC class I induce autoimmunity: role in the pathogenesis of chronic rejection. $J$ Immunol 2009;182:309-318.

Fukuda K, Koshihara Y, Oda H, Ohyama M; OoyamaT. Type V collagen selectively inhibits human endothelial cell proliferation. Biochem Biopbys Res Commun. 1988; 151:1060-68.

Gao MQ, Kim GB, Kang S, Choi PY, Park H, Kang KS, et al. Stromal fibroblasts from the interface zone of human breast carcinomas induce an epithelialmesenchymal transition-like state in breast cancer cells in vitro. J Cell Sci. 2010;123:3507-14.

Gelse K, Poschl E, Aigner T. Collagens: strutcture, function and byosynthesis. Advanced Drug Delivery Reviews. 2003;55:1531-46.

Gourh P, Agarwal SK, Divecha D, Assassi S, Paz G, Arora-Singh RK, et al. Polymorphisms in TBX21 and STAT4 increase the risk of systemic sclerosis: evidence of possible gene-gene interaction and alterations in Th1/Th2 cytokines. Arthritis Rheum. 2009;60:3794-806. 
Gourh P, Agarwal SK, Martin E, Divecha D, Rueda B, Bunting H, et al. Association of the C8orf13-BLK region with systemic sclerosis in NorthAmerican and European populations. J Autoimmun. 2010a;34:155-62.

Gourh P, Arnett FC, Tan FK, Assassi S, Divecha D, Paz G, et al. Association of TNFSF4 (OX40L) polymorphisms with susceptibility to systemic sclerosis. Ann Rheum Dis. 2010b;69:550-5.

Gourh P, Tan FK, Assassi S, Ahn CW, McNearney TA, Fischbach M, et al. Association of the PTPN22 R620W polymorphism with anti-topoisomerase Iand anticentromere antibody-positive systemic sclerosis. Arthritis Rheum. 2006;54:3945-53.

Grossman C, Dovrish Z, Shoenfeld Y, Amital H. Do infections facilitate the emergence of systemic sclerosis? Autoimmun Rev. 2011;10:244-7.

Grotendorst GR. Connective tissue growth factor: A mediator of TGF-b action on fibroblasts. Cytokine Growth Factor. 1997; 8:171-9.

Gruschwitz M, von den Driesch P, Kellner I, Hornstein OP, Sterry W. Expression of adhesion proteins involved in cell-cell and cell-matrix interactions in the skin of patients with progressive systemic sclerosis. J Am Acad Dermatol. 1992;27:169-77.

Gruschwitz MS, Hornstein OP, von der DP. Correlation of soluble adhesion molecules in the peripheral blood of slceroderma patients with their in situ expression and with disease activity. Arthritis Rheum. 1995;38:184-9.

Haque MA, Mizobuchi T, Yasufuku K, Fujisawa T, Brutkiewicz RR, Zheng Y, et al. Evidence for immune responses to a self-antigen in lung transplantation: role 
of type $\mathrm{V}$ collagen-specific $\mathrm{T}$ cells in the pathogenesis of lung allograft rejection. J Immunol. 2002;16:1542-9.

Hebbar M, Peyrat JP, Hornez L, Hatron PY, Hachulla E, Devulder B. Increased concentrations of the circulating angiogenesis inhibitor endostatin in patients with systemic sclerosis. Arthritis Rheum. 2000;43:889-93.

Henault J, Robitaile G, Senecal JL, Raymd Y. DNA topoisomerase I binding to fibroblasts induces monocyte adhesion $d$ activation in the presence of antitopoisomerase I autoantibodies from systemic sclerosis patients. Arthritis Rheum. 2006; 54:963-73.

Horstmeyer A, Licht C, Scherr G, Eckes B, Krieg T. Signalling and regulation of collagen I synthesis by ET1 and TGF-beta1. FEBS J. 2005;272:6297-309.

Hudson M, Thombs BD, Steele R, Panopalis P, Newton E, Baron M. Healthrelated quality of life in systemic sclerosis: a systematic review. Arthritis Rheum. 2009; 61:1112-20.

Igarashi A, Nashiro K, Kikuchi K, Sato S, Ihn H, Fujimoto M, et al. Connective tissue growth factor gene expression in tissue sections from localized scleroderma, keloid, and other fibrotic skin disorders. J Invest Dermatol. 1996; 106:729-33.

Ihn H, Sato S, Fujimoto M, Kikuchi K, Kadono T, Tamaki K, et al. Circulating intercellular adhesion molecule-1 in the sera of patients with systemic sclerosis: enhancement by inflammatory cytokines. Br J Rheumatol. 1997;36:1270-75.

Ihn H, Sato S, Fujimoto M, Takehara K, Tamaki K. Increased serum levels of soluble vascular cell adhesion molecule-1 and E-selectin in patients with systemic sclerosis. Br J Rheumatol. 1998;37:1188-92. 
Ito I, Kawaguchi Y, Kawasaki A, Hasegawa M, Ohashi J, Hikami K, et al. Association of a functional polymorphism in the IRF5 region with systemic sclerosis in a Japanese population. Arthritis Rheum. 2009;60:1845-50.

Ito I, Kawaguchi Y, Kawasaki A, Hasegawa M, Ohashi J, Kawamoto M, et al. Association of the FAM167A-BLK region with systemic sclerosis. Arthritis Rheum. 2010;62:890-5.

Joven BE, Almodovar R, Carmona L, Carreira PE. Survival, causes of death, and risk factors associated with mortality in Spanish systemic sclerosis patients: results from a single university hospital. Semin Arthritis Rheum. 2010;39:28593.

Jun, BJ, Kuechle M, Harlan JM, Elkon KB. Fibroblast and endothelial cell apoptosis in systemic sclerosis. Cur Opin Rheumatol. 2003:756-60.

Jymenez AS, Arlett CM.Michrochimerism and systemic sclerosis. Current Opinion in Rheumatology. 2005;17:86-90.

Kalabay L, Fekete B, Czirjak L, et al. Helicobacter pylori infection in connective tissue disorders is associated with high levels of antibodies to mycobacterial hsp65 but not to human hsp60. Helicobacter. 2002;7:250-6.

Kikuchi K, Kubo M, Kadono T, Yazawa N, IHN H, Tamaki K. Serum concentrations of vascular endothelial growth factor in collagen diseases. $\mathrm{Br} \mathrm{J}$ Dermatol. 1998;139:1049-51.

Kiener H, Graninger W, Machold K, Aringer M, Graninger WB. Increased levels of circulating intercellular adhesion molecule-1 in patients with systemic sclerosis. Clin Exp Rheumatol. 1994;12:483-87. 
Kurasawa K, Hirose K, Sano H, Endo H, Shinkai H, Nawata Y, et al. Increased interleukin-17 production in patients with systemic sclerosis. Arthritis Rheum. 2000;43:2455-63.

Kuwana M, Inoko H, Kameda H, Nojima T, Sato S, Nakamura K, et al. Association of human leukocyte antigen class II genes with autoantibody profiles, but not with disease susceptibility in Japanese patients with systemic sclerosis. Intern Med. 1999;38:336-44.

Laemmli UK. Cleavage of structural proteins during the assembely of the head of the bacteriophage T4. Nature. 1970; 680-5.

Laplante P, Raymond MA, Gagnon G, Vigneault N, Sasseville AM, Langelier Y, et al. Novel fibrogenic pathways are activated in response to endothelial apoptosis: implications in the pathophysiology of systemic sclerosis. $J$ Immunol. 2005;174:5740-9.

Laplante P, Sirois I, Raymond MA, Kokta V, Béliveau A, Prat A, Pshezhetsky AV, Hébert MJ. Caspase-3-mediated secretion of connective tissue growth factor by apoptotic endothelial cells promotes fibrosis. Cell Death Differ. 2010;17:291-303.

Le Roy EC, Black C, Fleischmajer R, Jablonska S, Krieg T, Medsger TA Jr, et al. Scleroderma (systemic sclerosis): classification, subsets and pathogenesis. J Rheumatol. 1988; 15:202-5.

Lin Z, Natesan V, Shi H, Hamik A, Kawanami D, Hao C, et al. A novel role of CCN3 in regulating endothelial inflammation. J Cell Commun Signal. 2010;4:141-53. 
Liu T, Zhang J: Detection of V, III and I type collagens of dermal tissues in skin lesions of patients with systemic sclerosis and its implication. J Huazhong Univ Sci Technolog Med Sci. 2008; 28:599-603.

Livak NJ, Schmittgen TD. Analysis of relative gene expression data using realtime quantitative PCR and the 2[-Delta-Delta $\mathrm{C}(\mathrm{T})]$ method. Methods. $2001 ; 25: 402-8$.

Luparello C, David F, Campisi G, Sirchia R. T47-D cells and type V collagen: A model for study of apoptotic gene expression by breast cancer cells. Biol Chem. 2003; 381:965-75.

Luparrelo $\mathrm{C}$, Sirchia R. Type $\mathrm{V}$ collagen regulates the expression of apoptotic and stress renponse genes by breast cancer cells. J Cell Physiol. 2005; 202:411-21.

Lunardi C, Bason C, Navone R, Millo E, Damonte G, Corrocher R, Puccetti A. Systemic sclerosis immunoglobulin $G$ autoantibodies bind the human cytomegalovirus late protein UL94 and induce apoptosis in human endothelial cells. Nat Med. 2000;6:1183-6.

Luscher TF, Yang Z, Tschudi M, et al. Interaction between endothelin-1 and endothelium-derived relaxing factor in human arteries and veins. Circ Res. 1990; 66: 1088-94.

Mackiewicz Z, Sukura A, Povilenaité D, Ceponis A, Virtanen I, Hukkanen M, et al. Increased but imbalanced expression of VEGF and its receptors has no positive effect on angiogenesis in systemic sclerosis skin. Clin Exp Rheumatol. 2002; 20:641-6. 
Magro CM, Nuovo G, Ferri C, Crowson AN, Giuggioli D, Sebastiani M. Parvoviral infection of endothelial cells and stromal fibroblasts: a possible pathogenetic role in scleroderma. J Cutan Pathol. 2004;31:43-50.

Malfait F, Wenstrup RJ, De Paepe A. Clinical and genetic aspects of EhlersDanlos syndrome, classic type. Genet Med. 2010;12:597-605.

Manetti M, Guiducci S, Ibba-Manneschi L, Matucci-Cerinic M. Mechanisms in the loss of capillaries in systemic sclerosis: angiogenesis versus vasculogenesis. J Cell Mol Med. 2010;14:1241-54.

Marangoni RG, Parra ER, Barbeiro HV, Velosa APP, Soriano VG, Teodoro WR, Yoshinari $\mathrm{NH}$. Experimental model of systemic sclerosis induced by collagen $\mathrm{V}$ reproduces extra and intrapulmonary artery disfunction. Clin and Exp Rheumatol. 2010a; 5 Suppl 62:31.[Abstract]

Marangoni RG, Parra ER, Velosa APP, Teodoro WR, Capelozzi VL, Yoshinari $\mathrm{NH}$. Endothelial Dysfunction and abnormal COLV deposition in pulmonary vasculature of experimental systemic sclerosis model. Arthritis and Rheum. 2010b; 62S:253. [Abstract]

Marangoni RG. Estudo da vasculopatia pulmonar no modelo experimental de esclerodermia induzido pelo colágeno do tipo V. [tese]. São Paulo: Faculdade de Medicina da Universidade de São Paulo, 2011

Massagué J, Gomis RR. The logic of TGFbeta signaling. FEBS Lett. 2006;580:2811-20.

Miller EJ, Rhodes RK. Preparation and characterization of the different types of collagen. Methods Enzymol. 1982; 82 Pt A:33-64. 
Minier T, Péntek M, Brodszky V, Ecseki A, Kárpáti K, Polgár A, et al. Cost-ofillness of patients with systemic sclerosis in a tertiary care center. Rheumatology. 2010b;49:1920-8.

Mori Y, Chen SJ, Varga J. Expression and regulation of intracellular SMAD signaling in scleroderma skin fibroblasts. Arthritis Rheum. 2003;48:1964-78.

Moussad EE, Brigstock DR. Connective tissue growth factor: what's in a name? Mol Genet Metab. 2000;71:276-92.

Moustakas A, Heldin CH. Non-Smad TGF-beta signals. J Cell Sci. 2005;118:3573-84.

Mulligan-Kehoe MJ, Drinane MC, Mollmark J, Casciola-Rosen L, Hummers LK, Hall A, et al. Antiangiogenic plasma activity in patients with systemic sclerosis. Arthritis Rheum. 2007; 56:3448-58.

Murakosi N, Miyauchi T, Kakinuma Y, et al. Vascular endothelin -B receptor system in vivo plays a favourable inhibitory role in vascular remodelling after injury revealed by endothelin-B receptor knock-out mice. Circulation. 2002; 106: 1991-8.

Muehlich S, Cicha I, Garlichs CD, Krueger B, Posern G, Goppelt-Struebe M. Actin-dependent regulation of connective tissue growth factor. Am J Physiol Cell Physiol. 2007;292: C1732-8.

Murdaca G, Colombo BM, Cagnati P, Gulli R, Spanò F, Puppo F. Endothelial dysfunction in rheumatic autoimmune diseases. Atherosclerosis. 2012 may 18. [Epub ahead of print].

Murphy M, Godson C, Cannon S, Kato S, Mackenzie HS, Martin F, et al. Supression substractive hybridization indentifies high gluocxse levels as a 
stimulus for expression of connective tissue growth factor and others genes in human mesangial cells. J Biol Chem. 1999; 274:1665-1667.

Nietert PJ, Silver RM. Systemic sclerosis: environmental and occupational risk factors. Current Opinion in Rheumatology. 2000;12:520-6.

Nietert PJ, Silverstein MD, Silver RM. Hospital admissions, length of stay, charges, and in-hospital death among patients with systemic sclerosis. J Rheumatol. 2001;28:2031-7.

Notbohm H, Nokelainen M, Myllyharju J, Fietzek PP, Muller PK, Kivirikko KL. Recombinant human type II collagens with ow and high levels of hydroxylysine and its glycosylated forms show marked differences in fibrillogenesis in vitro. J. Biol. Chem. 1999;274:8988-92.

Ogido LT, Teodoro WR, Velosa AP, de Oliveira CC, Parra ER, Capelozzi VL, Yoshinari $\mathrm{NH}$. Abnormal collagen deposition in synovia after collagen type $\mathrm{V}$ immunization in rabbits. Histol Histopathol. 2008;23:263-9.

Pandey P, LeRoy EC. Human cytomegalovirus and the vasculopathies of autoimmune diseases (especially scleroderma), allograft rejection, and coronary restenosis. Arthritis Rheum. 1998;41:10-5.

Pannu J, Trojanowska M. Recent advances in fibroblast signaling and biology in scleroderma. Curr Opin Rheumatol. 2004;16:739-45.

Pannu J, Gardner H, Shearstone JR, Smith E, Trojanowska M. Increased levels of transforming growth factor beta receptor type I and up regulation of matrix gene program. Arthritis Rheum. 2006;54:3011-21. 
Papaioannou Al, Zakynthinos E, Kostikas K, Kiropoulos T, Koutsokera A, Ziogas A, et al. Serum VEGF levels are related to the presence of pulmonary arterial hypertension in systemic sclerosis. BMC Pulm Med. 2009; 9:9-18.

Parra ER, Aguiar AC Jr, Teodoro WR, de Souza R, Yoshinari NH, Capelozzi VL. Collagen V and vascular injury promote lung architectural changes in systemic sclerosis. Clin Respir J. 2009; 3:135-42.

Parra ER, Teodoro WR, de Morais J, Katayama ML, de Souza R, Yoshinari NH, Capelozzi VL. Increased mRNA expression of collagen V gene in pulmonary fibrosis of systemic sclerosis. Eur J Clin Invest. 2010;40:110-20.

Phan SH, Gharaee-Kermani M, Wolber F, Ryan US. Stimulation of rat endothelial cell transforming growth factor-beta production by bleomycin. J Clin Invest. 1991;87:148-54.

Porter AG, Jänicke RU. Emerging roles of caspase-3 in apoptosis. Cell Death Differ. 1999;6:99-104.

Postlethwaite AE, Holness MA, Katai $H$, Raghow R. Human fibroblasts synthesize elevated levels of extracellular matrix proteins in response to interleukin 4. J Clin Invest. 1992; 90:1479-85.

Prescott RJ, Freemont AJ, Jones CJ, Hoyland J, Fielding P. Sequential dermal microvascular and perivascular changes in the develpment of scleroderma. $J$ Pathol. 1992;166:255-63.

Pucci-Minafra I, Carella C, Cirincione R, Chimeti S, Minafra S, Luparello C. Type $\mathrm{V}$ collagen induces apoptosis of $8701-\mathrm{BC}$ breast cancer and enhances $\mathrm{m}$ calpain expression. Breast Cancer Res. 2000; 2:E008. 
Querfeld C, Sollberg S, Huerkamp C, Eckes B, Krieg T. Pseudoscleroderma associated with lung cancer: Correlation of collagen type I and connective tissue growth factor gene expression. Br J Dermatol. 2000; 142:1228-1233.

Quinones F, Crouch E: Biosynthesis of interstitial and basement membrane collagens in pulmonary fibrosis. Am Rev Resp Dis. 1986; 134:1163-71.

Ranque B, Mouthon L. Geoepidemiology of systemic sclerosis. Autoimmunity Reviews. 2010; A311-8.

Recchia AG, Filice E, Pellegrino D, Dobrina A, Cerra MC, Maggiolini M. Endothelin-1 induces connective tissue growth factor expression in cardiomyocytes. J Mol Cell Cardiol. 2009;46:352-9.

Reveille JD, Fischbach M, McNearney T, Friedman AW, Aguilar MB, Lisse J, et al. Systemic sclerosis in 3 US ethnic groups: a comparison of clinical, sociodemographic, serologic, and immunogenetic determinants. Semin Arthritis Rheum. 2001;30:332-46.

Ricupero DA, Rishikof DC, Kuang PP, Poliks CF, Goldstein RH. Regulation of connective tissue growth factor expression by prostaglandin $\mathrm{E}(2)$. Am J Physiol. 1999; 277:L1165-L1171.

Riente L, Marchini B, Dolcher MP, Puccetti A, Bombardieri S, Migliorini P. Anticollagen antibodies in systemic sclerosis and in primary Raynaud's phenomenon. Clin Exp Immunol. 1995;102:354-9.

Riser BL, Denichilo M, Cortes P, Baker C, Grondin JM, Yee J, Narins RG. Regulation of connective tissue growth factor activity in cultured rat mesangial cells and its expression in experimental diabetic glomerulosclerosis. J Am Soc. 2000; Nephrol 11:25-38. 
Risau W. Mechanisms of angiogenesis. Nature. 1997;386:671-4.

Risau W, Flamme I. Vasculogenesis. Annu.Rev.CellDev.Biol.1995;11:73-91.

Rodriguez-Vita J, Ruiz-Ortega M, Rupérez M, Esteban V, Sanchez-López E, Plaza JJ, et al. Endothelin-1, via ETA receptor and independently of transforming growth factor-beta, increases the connective tissue growth factor in vascular smooth muscle cells. Circ Res. 2005;97:125-34.

Rosa JE, Soriano ER, Narvaez-Ponce L, del Cid CC, Imamura PM, Catoggio LJ. Incidence and prevalence of systemic sclerosis in a healthcare plan in Buenos Aires. J Clin Rheumatol. 2011;17:59-63.

Rudnicka L, Majewski S, Blaszczyk M et al. Adhesion of peripheral blood mononuclear cells to vascular endothelium in patients with systemic sclerosis (scleroderma). Arthritis Rheum. 1992;35:771-5.

Rueda B, Broen J, Simeon C, Hesselstrand R, Diaz B, Suarez H, et al. The STAT4 gene influences the genetic predisposition to systemic sclerosis phenotype. Hum Mol Genet. 2009;18:2071-7.

Rueda B, Gourh P, Broen J, Agarwal SK, Simeon CP, Ortego-Centeno N, et al. BANK1 functional variants are associated with susceptibility to diffuse systemic sclerosis in Caucasians. Ann Rheum Dis. 2010;69:700-5.

Sakkas LI, Platsoucas CD. Is systemic sclerosis na antigen driven $T$ cell disease? Arthritis Rheum. 2004;50:1721-33. 
Sakkas LI, Xu B, Artlett CM, Lu S, Jimenez SA, Platsoucas CD. Oligoclonal T cell expansion in the skin of patients with systemic sclerosis. J Immunol. 2002;168:3649-59.

Samarin J, Wessel J, Cicha I, Kroening S, Warnecke C, Goppelt-Struebe M. FoxO proteins mediate hypoxic induction of connective tissue growth factor in endothelial cells. J Biol Chem. 2010; 285:4328-36.

Sargent JL, Milano A, Bhattachayya S, et al. A TGF $\beta$-responsive gene signature is associated with a subset of diffuse scleroderma with increased disease severity. J Invest Dermatol. 2010; 130:694-705.

Sato S. Abnormalities of adhesion molecules and chemokines in scleroderma. Curr Opin Rheumatol. 1999;11:503-7.

Sato S, Nagaoka T, Hasegawa M, Tamatani T, Nakanishi T, Takigawa M, et al. Serum levels of connective tissue growth factor are elevated in patients with systemic sclerosis: Association with extent of skin sclerosis and severity of pulmonary fibrosis. J Rheumatol. 2000; 27:149-54.

Shahgasempour S, Woodroffe SB, Sullivan-Tailyour G, Garnett HM. Alteration in the expression of endothelial cell integrin receptors alpha 5 beta 1 and alpha 2 beta 1 and alpha 6 beta 1 after in vitro infection with a clinical isolate of human cytomegalovirus. Arch Virol. 1997;142:125-38.

Sharif R, Mayes MD, Nicassio PM, Gonzalez EB, Draeger H, McNearney TA, et al. Determinants of Work Disability in Patients with Systemic Sclerosis: A Longitudinal Study of the GENISOS Cohort. Semin Arthritis Rheum. 2011;41:38-47. 
Schnitzer M, Hudson M, Baron M, Steele R. Disability in systemic sclerosis a longitudinal observational study. J Rheumatol. 2011;38:685-92.

Schwartz BR, Karsan A, Bombeli T, Harlan JM. A novel beta 1 integrindependent mechanism of leukocyte adherence to apoptotic cells. J Immunol. 1999; 162:4842-8.

Seibold J. Connective tissue disease characterized by fibrosis. In: Ruddy S, Harris ED Jr, Sledje CD. Textbook of Rheumatology, Vol. 2. Philadelphia: WB Saunders Co.; 2001. 1133-59.

Seibold JR, Korns $\mathrm{JH}$, Clements PJ, et al. Recombinant human relaxin in the treatment of scleroderma: a randomized double blind, placebo controled trial. Ann Intern Med. 2000;132:871-9.

Silman AJ. Scleroderma demographics and survival. J Rheumatol. 1997; 24:5861.

Sfikakis PP, Tesar J, Baraf H, Lipnick R, Klipple G, Tsokos GC. Circulating intercellular adhesion molecule-1 in patients with systemic sclerosis. Clin Immunol Immunopathol. 1993;68:88-92.

Sgonc R, Gruschwitz MS, Dietrich H, Recheis H, Gershwin ME, Wick G. Endothelial cell apoptosis is a primary pathogenetic event underlying skin lesions in avin and human scleroderma. J. Clin. Invest. 1996:785-92.

Sgonc R, Gruschwitz MS, Boeck G, Sepp N, Gruber J, Wick G. Endothelial cell apoptosis in systemic sclerosis is induced by antibody-dependent cell mediated cytotoxicity via CD95. Arthritis Rheum. 2000:2550-62.

Shi-Wen X, Chen Y, Denton CP, Eastwood M, Renzoni EA, Bou-Gharios G, et al. Endothelin-1 promotes myofibroblast induction through the ETA receptor via 
a rac/phosphoinositide 3-kinase/Akt-dependent pathway and is essential for the enhanced contractile phenotype of fibrotic fibroblasts. Mol Biol Cell. 2004a; 15:2707-19.

Shi-Wen X, Denton CP, Dashwood MR, Holmes AM, Bou-Gharios G, Pearson $\mathrm{JD}$,et al. Fibroblast matrix gene expression and connective tissue remodeling: role of endothelin-1. J Invest Dermatol. 2001;116:417-25.

Shi-Wen X, Howat SL,Renzoni EA, Holmes A, Pearson J, Dashwood MR, et al. Endothelin-1 Induces Expression of Matrix-associated Genes in Lung Fibroblasts through MEK/ERK. J Biol Chemetry. 2004b; 22:23098-23103

Shi-Wen X, Rodriguez-Pascual F, Lamas S, Holmes A, Howat S, Pearson JD, et al. Constitutive ALK5-independent c-Jun N-terminal kinase activation con tributes to endothelin-1 overexpression in pulmonary fibrosis: evidence of an autocrine endothelin loop operating through the endothelin $A$ and $B$ receptors. Mol Cell Biol. 2006; 26: 5518-27.

Sollberg S, Peltonen J, Uitto J, Jimenez SA. Elevated expression of beta1 anda beta 2 integrins, intercelullular adhesion molecule 1 and endothelial leukocite adhesion molelcule -1 in the skin of patients with systemic sclerosis of recent onset. Arthritis Rheum. 1992; 35:290-8.

Sondergaard K, Stengaard-Pedersen K, Zachariae H, Heickendorff L, Deleuran M, Deleuran B. Soluble intercellular adhesion molecule-1 (sICAM-1) and soluble interleukin-2 receptors (sIL-2R) in scleroderma skin. $\mathrm{Br} J$ Rheumatol. 1998; 37:304-10.

Sorrel MJ, Baber MM, Caplan AJ. Site matched papilary and reticular dermal fibroblasts difer in their release of specific growth factores, cytokines and their interaction with keratinocytes. J Cell pathol. 2004; 200:134-45. 
Souza P, Rizzardi F, Noleto G, Atanazio M, Bianchi O, Parra ER, Teodoro WR, Carrasco S, Velosa AP, Fernezlian S, Ab'saber AM, Antonângelo L, Takagaki T, Schainberg CG, Yoshinari NH, Capelozzi VL. Refractory remodeling of the microenvironment by abnormal type $\mathrm{V}$ collagen, apoptosis, and immune response in non-small cell lung cancer. Hum Pathol. 2010;41:239-48.

Spiess K, Teodoro WR, Zorn TMT. Distribution of collagen types I, III and V in pregnant mouse endometrium. Conective Tissue Res. 2007; 48:99-108.

Subcommittee for Scleroderma Criteria of the American Rheumatism Association Diagnostic and Therapeutic Criteria Committee: Preliminary Criteria for the Classification of Systemic Sclerosis (Scleroderma). Arthritis Rheum. 1980;23:581-92.

Teodoro WR, Witzel SS, Velosa APP, Shomokomaki M, Abrahamsolhn PA, Zorn TMT. Increase of Interstitial collagen in mouse endometrium during decidualization. Connective Tissue Res. 2003; 44:1-8.

Teodoro WR, Velosa APP, Witzel SS, Garipo AL, Farhat C, Parra ER, Sonohara S, Capelozzi VL, Yoshinari NH. Architectural remodeling in lungs of rabbits induced by type $\mathrm{V}$ collagen immunization: a preliminary morphologic model to study diffuse connective tissue diseases. Pathol Res Pract. 2004;200:681-91.

Valentini G, Della Rossa A, Bombardieri S, Bencivelli W, Silman AJ, D'Angelo $S$, et al. European multicentre study to define disease activity criteria for systemic sclerosis. II. Identification of disease activity variables and development of preliminary activity indexes. Ann Rheum Dis. 2001;60:592-8. 
Valentini G, Silman AJ, Veale D. Assessment of disease activity. Clin. Exp. Rheum. 2003; 21:S39-S41.

Vancheeswaran R, Azam A, Black C, Dashwood MR. Localization of endothelin-1 and its binding sites in scleroderma skin. $J$ Rheumatol. 1994a;21:1268-76.

Vancheeswaran R, Magoulas T, Efrat G, Wheeler-Jones C, Olsen I, Penny R, Black CM. Circulating endothelin-1 levels in systemic sclerosis subsets - a marker of fibrosis or vascular dysfunction? J Rheumatol. 1994b; 21:1838-44.

Varga J, Abraham D. Systemic sclerosis: a prototypic multisystem fibrotic disorder. J Clin Invest. 2007;117:557-67.

Veale DJ, Kirk G, McLaren M, Belch JJ. Clinical implications of soluble intercellular adhesion molecule-1 levels in systemic sclerosis. $\mathrm{Br} J$ Rheumatol. 1998; 37:1227-8.

Verhaar MC, Strachan FE, Newby DE, Cruden NL, Koomans HA, Rabelink TJ,et al. Endothelin-A receptor antagonist mediated vasodilatation is attenuated by inhibition of nitric oxide synthesis and by endothelin-B receptor blockade. Circulation. 1998; 97:752-6.

Weibel ER. Morphometry: stereological theory and practical methods. In: Gil J, editor. Models of Lung Disease - Microscopy and Structural Methods. New York, Marcel Dekker. 1990: 199-24.

Wells AU. High-resolution computed tomography and scleroderma lung disease. Rheumatology. 2008;47:v59-v61. 
Wenstrup RJ, Florer JB, Brunskill EW, Bell SM, Chervoneva I, Birk DE. Type V collagen controls the initiation of collagen fibril assembly. $J$ Biol Chem. 2004;279:53331-7.

Wenstrup RJ, Florer JB, Davidson JM, Phillips CL, Pfeiffer BJ, Menezes DW, et al. Murine model of the Ehlers-Danlos syndrome. col5a1 haploinsufficiency disrupts collagen fibril assembly at multiple stages. $J$ Biol Chem. 2006;281:12888-95.

White B, Bauer EA, Goldsmith LA, et al. Guidelines for clinical trials in systemic sclerosis (scleroderma). I. Disease-Modification Intervention. Arthritis Rheum. 1995;28:351-60.

Wigley FM. Vascular disease in scleroderma. C Rev Allerg Immuol. 2009; 36: 150-75.

Wigley FM, Hummers LK. Clinical features of systemic sclerosis. In: Hochberg MC, Silman AJ, Smolen JS, Weinblatt M and Weisman M. Rheumatology. London: Elsevier Limited. 2003:1463-79.

Worda M, Sgonc R, Dietrich H, Niederegger H,Sundick RS, Gershwin ME, et al. In vivo analysis of the apoptosis-inducing effect of antiendothelial cell antibodies in systemic sclerosis by chorionallantoic membrane assay. Arthritis and Rheum. 2003:2605-14.

Yamane K, Kashiwagi H, Suzuki N, Miyauchi T, Yanagisawa M, Goto K, et al. Elevated plasma levels of endothelin-1 in systemic sclerosis. Arthritis Rheum. 1991;34:243-4.

Yin Q, Nan HY, Zhang WH, Yan LF, Cui GB, Xiao F. Pulmonary microvascular endothelial cells from bleomycin induced rats promote the transformation and collagen synthesis of fibroblasts. J Cell Physiol. 2011; 226:2191-102. 
Yasufuku K, Heidler KM, O'Donnell PW, Smith GN Jr, Cummings OW, Foresman $\mathrm{BH}$, et al. Oral tolerance induction by type $\mathrm{V}$ collagen downregulates lung allograft rejection. Am J Respir Cell Mol Biol. 2001; 25:26-34.

Yasufuku K, Heidler KM, Woods KA, Smith GN Jr, Cummings OW, Fujisawa T et al. Prevention of bronchiolitis obliterans in rat lung allografts by type $\mathrm{V}$ collagen-induced oral tolerance. Transplantation. 2002; 73:500-5.

Yoshinari NH, Teodoro WR, Ogido LTI, Velosa APP, Prizon C, Miron B, Bissoli, JCC, Parra ERC, Capelozzi VL. Modelo experimental de doenças difusas do tecido conjuntivo (DDTC) induzido por colágeno V. Rev Bras Reumatol. 2002;42:295-305.

Zakrzewska K, Corcioli F, Carlsen KM, Giuggioli D, Fanci R, Rinieri A, et al. Human parvovirus B19 (B19V) infection in systemic sclerosis patients. Intervirology. 2009;52:279-82.

Ziats MP, Anderson JM. Human vascular endothelial cell attachment and growth inhibition by type V collagen. J Vasc Surg. 1998; 17:710-718. 


\section{APÊNDICE}

Artigo: "Abnormal collagen $\mathrm{V}$ deposition in dermis correlates with skin thickening and disease activity in systemic sclerosis" aceito para publicação na revista "Autoimmunity Reviews" in press 
Review

\title{
Abnormal collagen $\mathrm{V}$ deposition in dermis correlates with skin thickening and disease activity in systemic sclerosis 2 , 弥弥
}

\author{
Patricia Martin a, Walcy R. Teodoro a , Ana Paula P. Velosa a, Jymenez de Morais a , Solange Carrasco a,

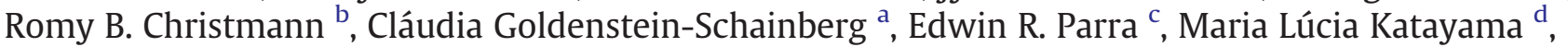 \\ Mirian N. Sotto ${ }^{\text {e }}$, Vera L. Capelozzi ${ }^{c}$, Natalino H. Yoshinari ${ }^{a}, *$
}

a Division of Rheumatology, Faculdade de Medicina da Universidade de São Paulo, São Paulo-SP, Brazil

${ }^{\mathrm{b}}$ Boston University School of Medicine, Boston, MA, USA

c Department of Pathology, Faculdade de Medicina da Universidade de São Paulo, São Paulo-SP, Brazil

d Division of Oncology, Faculdade de Medicina da Universidade de São Paulo, São Paulo-SP, Brazil

e Department of Dermatology, Faculdade de Medicina da Universidade de São Paulo, São Paulo-SP, Brazil

\section{A R T I C L E I N F O}

\section{Article history:}

Received 10 February 2012

Accepted 20 February 2012

Available online $\mathrm{xxxx}$

\section{Keywords:}

Systemic sclerosis

Type V collagen

Skin

Modified Rodnan Skin Score

Valentini Disease Activity Index

\begin{abstract}
A B S T R A C T
Objective: The physiological and mechanical properties of the skin, the primary tissue affected by systemic sclerosis, depend on the assembly of collagen types I, III and V, which form heterotypic fibers. Collagen V (COLV) regulates heterotypic fiber diameter, and the maintenance of its properties is important for maintaining normal tissue architecture and function. Based on a COLV-induced experimental SSc model, in which overexpression of abnormal COLV was a prominent feature, we assumed that this abnormality could be present in SSc patients and could be correlated to disease duration, skin thickening and disease activity. Methods: Skin biopsies from 18 patients (6 early-stage and 12 late-stage) and 10 healthy controls were studied. Skin thickening assessment was performed with the Modified Rodnan Skin Score (MRSS), and activity was calculated using the Valentini Disease Activity Index. Morphology, morphometry of COLV deposition in dermis, as well as, quantitative RT-PCR and 3D-reconstruction of the dermal fibroblast culture were performed.

Results: Structurally abnormal COLV was overexpressed in SSc skin, mainly in the early stages of the disease, when compared to normal controls and late-stage. A positive correlation between COLV expression and MRSS and disease activity was observed. Collagen V alpha-1 and alpha-2 mRNA expression levels were higher in SSc. Tridimensional reconstruction of SSc dermal heterotypic fibers confirmed the presence of atypical COLV.

Conclusion: Increased synthesis of abnormal COLV and its correlation with disease stage, activity and MRSS suggest that this collagen can be a possible trigger involved in the pathogenesis of SSc.
\end{abstract}

(c) 2012 Elsevier B.V. All rights reserved.

\section{Contents}

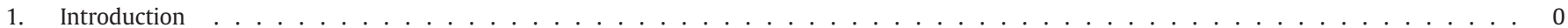

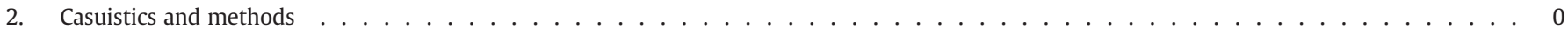

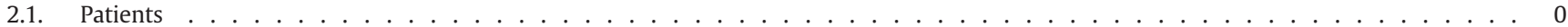

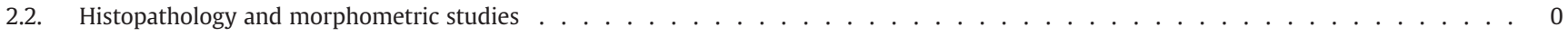

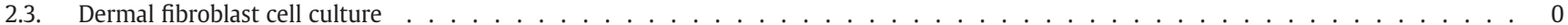

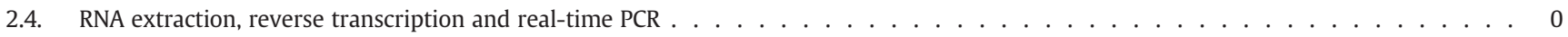

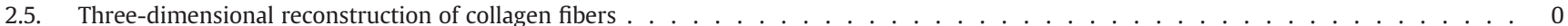

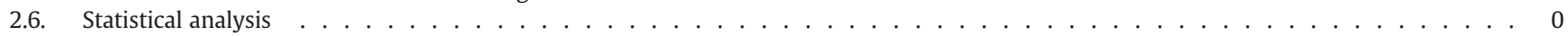

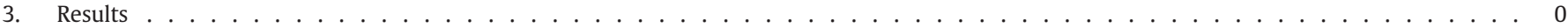

3.1. Expression of COLV, COLI and COLIII in the dermis of SSc patients and controls . . . . . . . . . . . . . . . . . . . . . . . . 0

\footnotetext{
放 Financial supporters: Fundação de Amparo a Pesquisa do Estado de São Paulo (FAPESP) and Federico Foundation.

约综 The authors do not have any conflict of interest.

* Corresponding author at: Av. Dr. Arnaldo 455, 3ªndar, sala 3138, CEP 01246-903, São Paulo-SP, Brazil. Tel: +55 1130617496.

E-mail address: yoshinari@lim17.fm.usp.br (N.H. Yoshinari).
} 


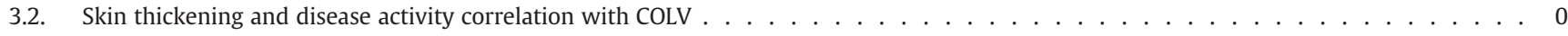

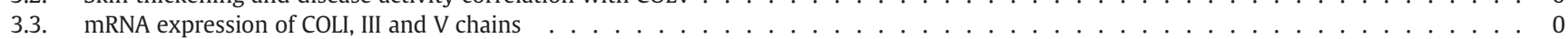

3.4. Three-dimensional reconstruction of COLI, COLIII and COLV in dermal fibroblast culture . . . . . . . . . . . . . . . . . . 0

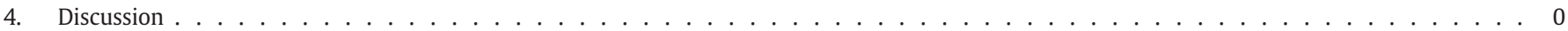

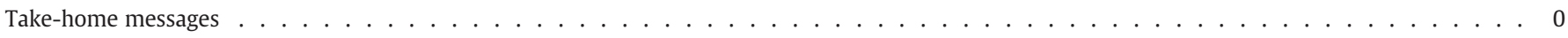

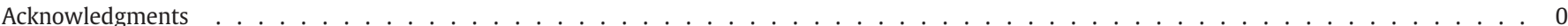

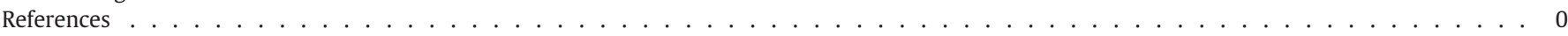

\section{Introduction}

Systemic sclerosis (SSc) is a chronic systemic disease characterized by autoimmunity, vascular lesions and progressive fibrosis of the internal organs and skin [1]. The fibrotic component is dominant in SSc, and is characterized by the accumulation of extracellular matrix components, mainly collagens [1], which results in a loss of tissue function [2].

The specific physiological and biochemical properties of the skin, the primary tissue affected by SSc, are based on the deposition of collagen types I, III and V, which coassemble into an unique macromolecule to form heterotypical fibers [3,4]. Type V collagen (COLV) is the minor component of these fibers and is found between COLI and COLIII fibrils. Only its amino-terminal portion, which regulates the diameter of heterotypic fibers, projects to the outer surface [5-7]. Thus, this collagen contributes to the development of functional connective tissues [6,7].

We previously observed an increased COLV expression in lungs of SSc patients and, of note, high deposition of this protein was associated with reduced vital capacity and diffusing capacity for carbon monoxide, indicating that this protein has a role in lung tissue SSc disorder [8,9]. COLV may be involved in SSc pathogenesis because immunization of health rabbits with this protein reproduces the main characteristics of SSc disease, including fibrosis [10,11], vasculopathy [12] and autoimmunity [13]. We have reported an increased expression of thickened COLV in the dermis of these rabbits, similar to human disease [11], but there is no studies evaluating the clinical relevance of COLV expression in the dermis of SSc. Based on these observations, we aimed to evaluate the histological and molecular profile of COLV in skin of SSc patients and its correlation with disease stage, clinical activity and skin thickness.

\section{Casuistics and methods}

\subsection{Patients}

Skin biopsy samples were obtained from the distal forearm dorsal surface of 18 SSc patients following American College of Rheumatology criteria [14]. Seven SSc patients were treatment-naïve, and eleven had not taken any antifibrotic or immunosuppressive treatment for the three months before the skin biopsy. Individuals presenting two years or less than their first non-Raynaud symptom were categorized as early-SSc, and those presenting more than two years from their first non-Raynaud symptom were categorized as late-SSc [15]. Skin thickening was assessed by trained rheumatologists (PM or RBC) using the Modified Rodnan Skin Score (MRSS) [16] and additional clinical data were collected from patients' records. SSc activity was calculated using the Valentini Disease Activity Index [17]. Fibroblast dermal cell cultures were performed in six of these patients, all of them treatment naïve. Skin tissues from healthy age- and sexmatched volunteers $(n=10)$ were obtained from plastic surgery procedures. Fibroblast dermal cell culture was performed in six of these subjects.

In compliance with the Helsinki Declaration, all patients and healthy controls provided informed consent for their participation in the study. The study was approved by the local ethical committee $($ CAPPesq $=0817 / 07)$.

\subsection{Histopathology and morphometric studies}

The skin biopsies were fixed in $10 \%$ formalin, embedded in paraffin and 3- to 4- $\mu \mathrm{m}$ sections were stained with hematoxylin and eosin (H\&E) and mounted on slides with 3-aminopropyltriethoxysilane (Sigma Chemical Co., St. Louis, MO, USA) for additional analysis.

Two pathologists (MNS and VLC) blinded to the patients' clinical features reviewed the skin specimens. The skin controls showed an absence of skin disease, and the histological diagnosis of SSc was confirmed when at least one of the following criteria was found with $\mathrm{H} \& \mathrm{E}$ staining [18]:

a) Normal-appearing dermal matrix but marked perivascular edema, perivascular mononuclear cell aggregation and/or basement membrane thickening or

b) Fibrosis with the encroachment of collagen onto appendages and/ or subcutaneous fat; elastosis and/or loss of definition between the reticular and papillary dermis; epidermal atrophy; and/or vascular disturbances, including venular dilation and decreased capillary numbers or

c) Dense, uniform dermal fibrosis; epidermal atrophy and adnexal loss.

To perform COLI, COLIII and COLV immunostaining, slides were mounted on 3-aminopropyltriethoxysilane (Sigma Chemical Co), dewaxed in xylol and hydrated in graded ethanol. Antigen retrieval was accomplished using enzymatic treatment with bovine pepsin (10,000 dry unit/ml) (Sigma Chemical Co.) in acetic acid buffer at $0.5 \mathrm{~N}$ for $30 \mathrm{~min}$ at $37^{\circ} \mathrm{C}$. For immunodetection of COLIII, nonspecific sites were blocked with $\mathrm{H}_{2} \mathrm{O}_{2} 3 \%$ for 25 min, then blocked with avidin and biotin (Vector Laboratories, Inc., Burlingame, CA, USA) for $10 \mathrm{~min}$ each, and finally blocked with $5 \%$ skim milk in phosphate buffer saline (PBS) for 30 min. To immunostain COLI and COLV, nonspecific sites were blocked only with $5 \%$ skim milk. The skin specimens were incubated overnight at $4{ }^{\circ} \mathrm{C}$ with rabbit polyclonal antihuman COLV [19] (1:50), rabbit polyclonal antihuman COLIII [19] (1:200) or rabbit polyclonal antihuman COLI antibodies [19] (1:150). The skin sections were washed in PBS with Tween $20.05 \%$ and incubated for $90 \mathrm{~min}$ at room temperature with goat anti-rabbit IgG antibody conjugated with fluorescein (Sigma Chemical Co.) diluted 1:50 in a PBS solution containing $0.006 \%$ Evans blue. Finally, the samples were mounted on buffered glycerol and analyzed using fluorescence microscopy (Olympus BX51, Olympus Co, Tokyo, Japan). For negative and autofluorescence controls, sections were incubated with PBS and normal rabbit serum instead of the specific antibody. For positive controls, we used tongue sections.

Histomorphometry was performed to quantify COLI, COLIII and COLV fiber density with image analysis of immunostained fibers. Briefly, the image analysis system consisted of an Olympus camera (Olympus Co, St Laurent, Quebec, Canada) coupled to an Olympus microscope (Olympus BX51), from which the images were sent to an LG monitor by means of a digitizing system (Oculus TCX, Coreco, Inc, St. Laurent, Quebec, Canada) and downloaded to a computer (Pentium 
$1330 \mathrm{Mhz})$. The images were then processed with software (Image Pro-Plus 6.0) [8]. The density of collagen fibers was measured in an area delimited by the basement membrane, including papillary and reticular dermis covering the microscopic field observed at a magnification of $\times 200$. Each field was deeper than $70 \mu \mathrm{m}$ to ensure that it covered both papillary and reticular dermis [20] when the limits between two layers were unclear due to SSc fibrosis. The threshold for collagen fibers was established for all slides after the contrast was enhanced to the point at which the fibers were easily identified as green bands. The collagen fiber density was expressed as the ratio between the number of measured fibers divided by the total area studied $\times 100$ [8]. All microscopic fields for each slide were quantified, and the results were expressed as the mean of these fields.

\subsection{Dermal fibroblast cell culture}

The primary fibroblast cell culture was developed using the explant method [21] immediately after the skin biopsy. The skin specimens were sectioned in small fragments and transferred to a large $25-\mathrm{cm}^{2}$ flask (Costar, USA) containing Dulbecco's Modified Eagle's Medium (DMEM) supplemented with 20\% fetal bovine serum, 1\% Lglutamine and $1 \%$ penicillin + streptomycin. The specimens were incubated at $37{ }^{\circ} \mathrm{C}$ in a $5 \% \mathrm{CO}_{2}$ atmosphere until the confluence of the cells. After $0.2 \%$ trypsin in PBS was added, the cells were transferred to a $75-\mathrm{cm}^{2}$ flask and treated as described above. Cells between 3 and 5 passages were used [22] to perform mRNA isolation and immunostaining.

\subsection{RNA extraction, reverse transcription and real-time PCR}

After the cells reached confluence in a $75-\mathrm{cm}^{2}$ flask, total RNA was isolated using the Trizol reagent (Invitrogen Corporation, Carlsbad, CA, USA), according to the manufacturer's protocol. Briefly, the total RNA $(4.0 \mu \mathrm{g})$ of the dermal fibroblasts was reverse-transcribed into complementary DNA (cDNA) using oligo $\mathrm{dT}_{12-18}$ primer (GE Healthcare Life Sciences, Little Chalfont, St Giles, UK) and Superscript III (Invitrogen Corporation, Carlbad, CA, USA). cDNA (1/20) was produced using SYBR Green Master Mix (Invitrogen). All samples were tested in duplicate. Cycling conditions were $60 \mathrm{~s}$ at $95{ }^{\circ} \mathrm{C}$, followed by 40 cycles of $60 \mathrm{~s}$ at $60{ }^{\circ} \mathrm{C}$ and $60 \mathrm{~s}$ at $72{ }^{\circ} \mathrm{C}$. Messenger RNA genes were amplified using specific primers (Invitrogen Corporation) at a final concentration of $250 \mathrm{nmol} / \mathrm{l}$. Primer sets were designed based on the coding region closest to the $3^{\prime}$ end of the gene using Primer3 (http://frodo.wi.mit.edu/cgi-bin/primer3/primer3_www.cgi) as follows Table 1:

The samples were analyzed by the Rotor-Gene 6 System software (Corbett Research, Mortlake, Australia). The results displaying a CT were further used to calculate average values. Data were expressed as CT values (the cycle number at which logarithmic PCR plots cross a calculated threshold line). The relative expression of genes of interest was normalized to that of ACT $\beta$, and CDNA obtained from a pool of cells was used as a reference. The comparative CT method (CT) was used to quantify gene expression, and relative expression was calculated as $2^{-\Delta \Delta \mathrm{CT}}[23,24]$.

Table 1

Oligonucleotides employed for quantitative RT-PCR.

\begin{tabular}{lll}
\hline Gene & Left $\left(5^{\prime} \rightarrow 3^{\prime}\right)$ & Right $\left(5^{\prime} \rightarrow 3^{\prime}\right)$ \\
\hline COLI $\alpha_{1}$ & AACAGCCGCTTCACCTACAG & TGGGATGGAGGGAGTTTACA \\
COLIII $\alpha_{1}$ & GATGGGGTCAAATGAAGGTG & TGATCAGGACCACCAATGTC \\
COLV $\alpha_{1}$ & GTGGCACAGAATTGCTCTCA & GTGGCACAGAATTGCTCTCA \\
$\operatorname{COLV~} \alpha_{2}$ & GGAAATGTGGGCAAGACTGT & TTGATGGTGGTGCTCATTGT \\
ACTB & AGAAAATCTGGCACCACACC & AGAGGCGTACAGGGATAGCA \\
\hline
\end{tabular}

\subsection{Three-dimensional reconstruction of collagen fibers}

For COLI, COLIII and COLV immunostaining, some skin fragments were placed on cover slips that were placed in 24-well plaques, and fibroblasts were cultivated until the confluence of the cells.

To detect COLI, COLIII and COLV in the fibroblast culture, these cells were fixed with $4 \%$ paraformaldehyde for $1 \mathrm{~h}$ at $4{ }^{\circ} \mathrm{C}$. Double immunofluorescence was conducted using fibroblast incubation with rabbit polyclonal antihuman COLI [19], rabbit polyclonal anti human COLIII [19] and mouse polyclonal antihuman COLV antibody [19], all diluted 1:20 in PBS. Alexa 488-conjugated goat anti-mouse IgG (1:200, Invitrogen, Eugene, OR, USA) and Alexa 633-conjugated goat anti-rabbit IgG (1:200, Invitrogen) were used as secondary antibodies. The nuclei were counterstained with $1 \mu \mathrm{g} / \mathrm{ml}$ bisbenzimide Hoechst 33258 (Invitrogen). The fibroblastic nature of the isolated cells was confirmed via the microscopic determination of morphology and immunofluorescence characterization using antibodies against vimentin (1:800; Dako, Denmark) [25]. Finally, the reaction was observed with a confocal laser-scanning microscope (Zeiss LSM 510 META/UV, Germany) for the 3D reconstruction of collagen fibers.

\subsection{Statistical analysis}

After a data normality check using the Kolmogorov-Smirnov test, statistical analysis was performed using the Mann-Whitney test for two continuous variables and Kruskal-Wallis test for $k$ continuous variables, followed by the appropriate post hoc tests. Fisher exact test was used for nominal variables. The correlations of dermis collagen expression with disease duration, activity and MRSS were determined using the rank correlation (Spearman's coefficient). The level of significance was set at $5 \%$.

\section{Results}

The main clinical features of SSc patients can be observed in Table 2. These characteristics did not differ markedly between patients whose samples were used in histological analysis and those whose samples were utilized in fibroblasts dermal culture.

Table 2

Clinical and laboratorial features of SSc patients.

\begin{tabular}{llll}
\hline & Histology & $\begin{array}{l}\text { Fibroblast } \\
\text { culture }\end{array}$ & $\mathrm{p}^{*}$ \\
\hline Number & 18 & 6 & \\
Age, median (range) & 47.5 & 30 & 0.53 \\
& $(21-58$ years) & $(21-59$ years) & \\
Females, N (\%) & $16(88.88)$ & $6(100)$ & 1 \\
Diffuse cutaneous SSc, N (\%) & $12(66.66)$ & $5(83.33)$ & 0.62 \\
Limited cutaneous SSc, N (\%) & $6(44.44)$ & $1(16.66)$ & 0.62 \\
Early-SSc ${ }^{* *}, \mathrm{~N}(\%)$ & $6(33.33)$ & $4(66.66)$ & 0.19 \\
Median (range) & 12 & 12 & 0.38 \\
& $(4-24$ months) & $(6-24$ months) & \\
Late-SSc, N (\%) & $12(77.77)$ & $2(33.33)$ & 0.19 \\
Median (range) & 8.5 & 3.25 & 0.09 \\
MRSS, median (range) & $(5-29$ years) & $(2.5-4$ years) & \\
Valentini Disease Activity index, & $25(11-40)$ & $21(10-33)$ & 0.78 \\
median (range) & $3(0.5-5)$ & $3.5(1-4.5)$ & 0.89 \\
Active disease *** $^{*}$, N (\%) & & & \\
Interstitial pulmonary disease ${ }^{* * * *}, \mathrm{~N}(\%)$ & $14(66.67)$ & $4(66.66)$ & 0.61 \\
Positive antinuclear antibody N (\%) & $18(100)$ & $6(100)$ & - \\
Positive anti-Scl70 antibody, N (\%) & $8(44.44)$ & $4(66.66)$ & 0.64 \\
Positive anticentromere antibody, N (\%) & $2(11.11)$ & $1(16.66)$ & 1 \\
\hline
\end{tabular}

* Groups were compared using Mann-Whitney test for continuous variables and exact Fisher test for nominal variables.

** 2 years or less since the first non-Raynaud's phenomenon symptom [15].

*** According to the Valentini Disease Activity Index [17].

**** Forced vital capacity $<70 \%$ of predicted or ground glass opacities or fibrosis at thorax scanning [26,27]. 
3.1. Expression of COLV, COLI and COLIII in the dermis of SSC patients and controls

Immunofluorescence analysis of the skin biopsies was performed to evaluate the pattern of COLV distribution in the dermis of SSc patients and controls.

COLV analysis in control specimens showed loose, thin fibers in a homogeneous, linear distribution along the basement membrane (Fig. 1A-B) and around the vessels (Fig. 1C) as well in the dermis in a wavy distribution consistent with the normal tissue architecture (Fig. 1A). In contrast, early-SSc specimens exhibited thick COLV fibers in a band distribution along the basement membrane (Fig. 1D-E) and small vessels (Fig. 1F) as well as tightly packed in the dermis (Fig. 1D). In late-SSc samples, the COLV fibers were thick and assumed an irregular and micronodular distribution involving the basement membrane (Fig. 1G-H), small vessels (Fig. 1I) and dermis. They were also found as tightly packed fibers in some areas.

Quantitative analysis showed an increased COLV expression in the dermis of both early- and late-SSc patients compared with healthy controls. In fact, early-SSc patients exhibited 91.66\% higher COLV expression than control group and late-SSc patients showed a $42.75 \%$ higher expression of COLV than the healthy controls. When the COLV expression of early- and late-SSc samples was compared, this protein was expressed at higher levels in the early stages of disease (Fig. 1J). In addition, there was a negative correlation between COLV and disease duration in months $(\mathrm{r}=-0.44, \mathrm{p}=0.03)$, as regression line observed in Fig. 1K.

Because COLI and COLIII are important components of heterotypical fibers and are also increased in SSc patients, we also evaluated these collagens. Regarding COLI, in control dermis, these fibers were loosely arranged along the basement membrane (Fig. 2A-B), assuming a basket-weave pattern in the papillary and reticular layers (Fig. 2A) and sometimes enhancing small vessel walls (Fig. 2C). A similar pattern of COLI fiber distribution along the basement membrane (Fig. 2D and E) and dermis (Fig. 2D) was observed in earlySSc skin, although the enhancement of small vessels is more prominent (Fig. 2F). In contrast, in late-SSc, thick COLI fibers were tightly packed from the basement membrane (Fig. $2 \mathrm{G}-\mathrm{H}$ ) to the papillary and reticular layers (Fig. 2G) and the small vessels (Fig. 2I), modifying the usual histoarchitecture of the dermis.

Quantitative analysis of the fluorescence density revealed increased COLI expression in late-SSc patients when compared with controls and early-SSc patients. In fact, late-SSc dermis showed a $31.70 \%$ increase in COLI expression when compared with healthy controls, and a 34.14\% increase in COLI expression when compared with early-SSc skin (Fig. 2J). Furthermore, a positive correlation between COLI deposition and disease duration in months was noted $(\mathrm{r}=0.59, \mathrm{p}=0.015)$ and regression line can be observed in Fig. $2 \mathrm{~K}$.

Thin COLIII fibers were visualized predominantly around the small vessels (Fig. 3A-C) and dermis (Fig. 3A) of healthy controls. These
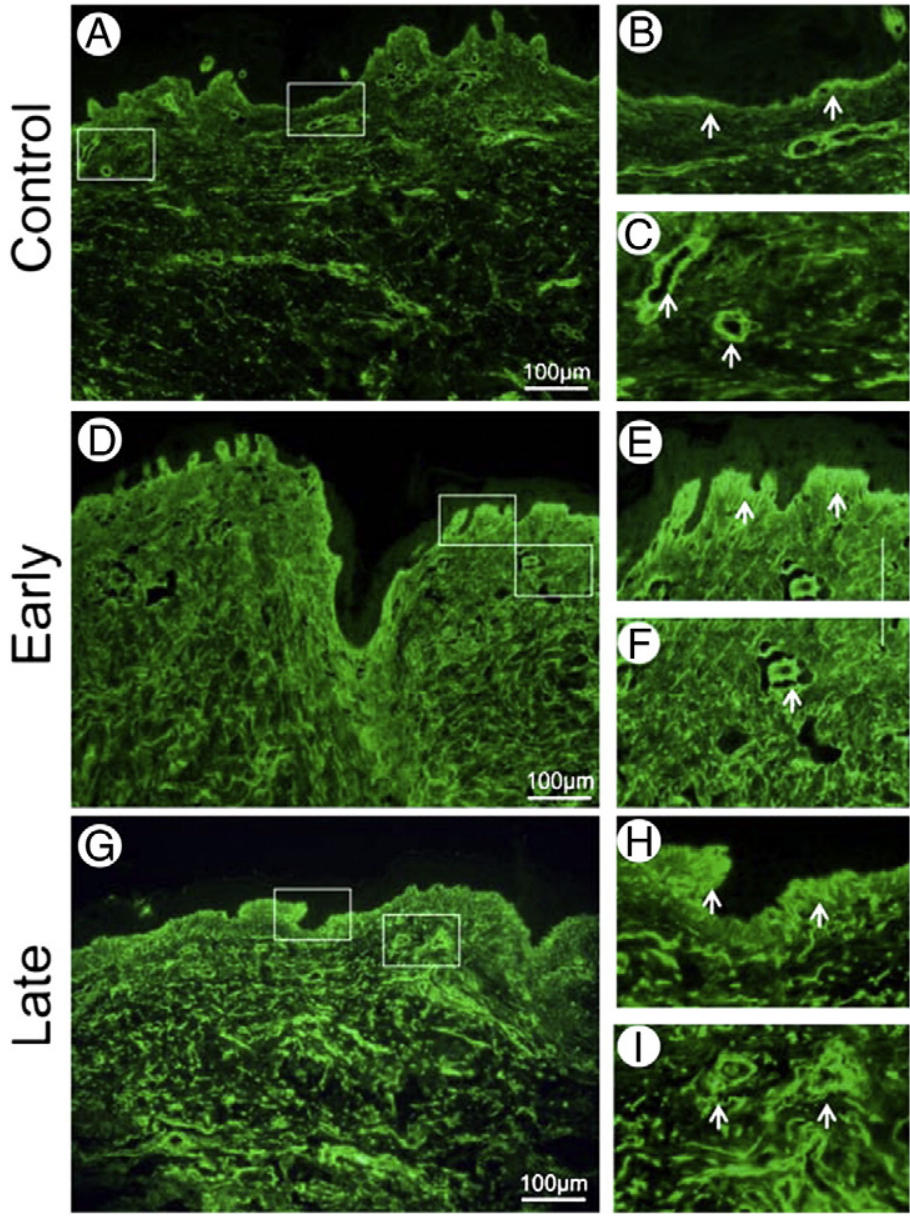

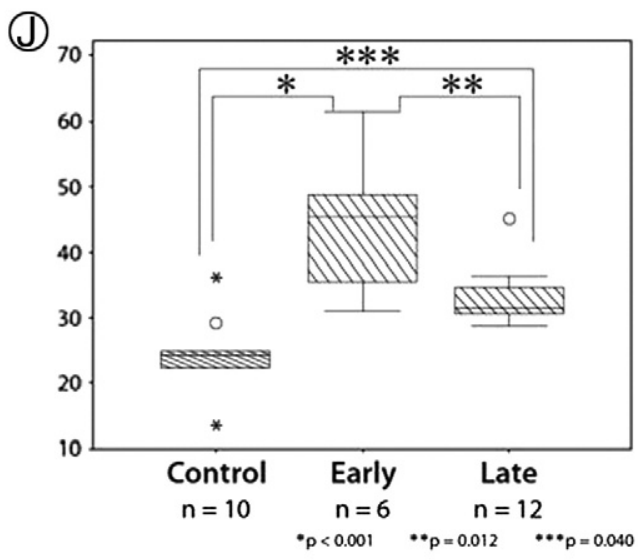

(1)

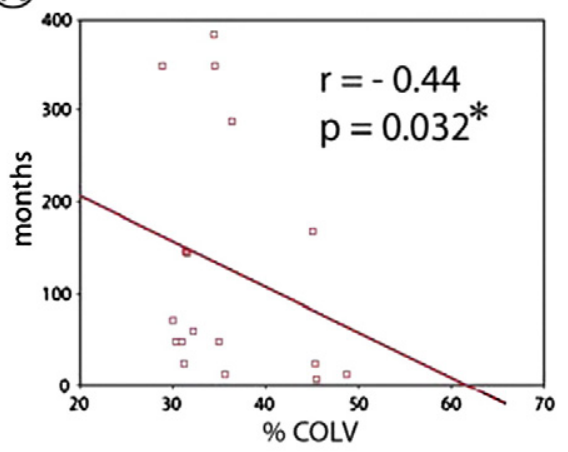

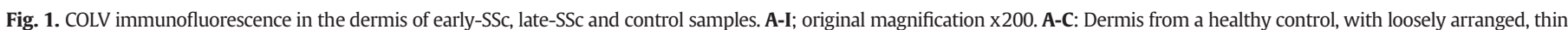

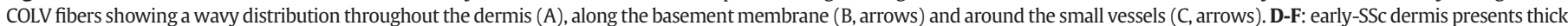

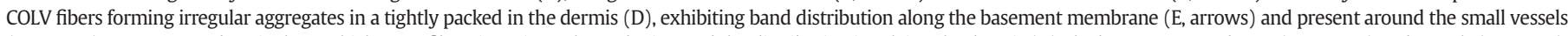

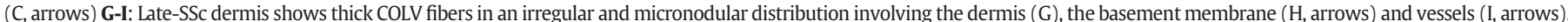

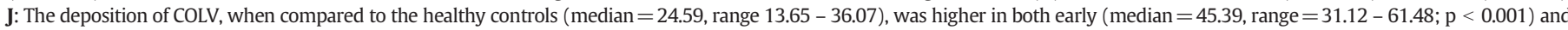

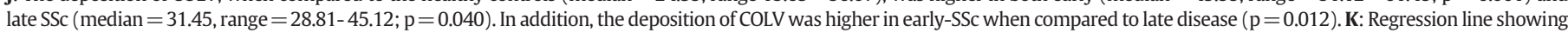
a negative correlation between COLV and disease duration in months. 

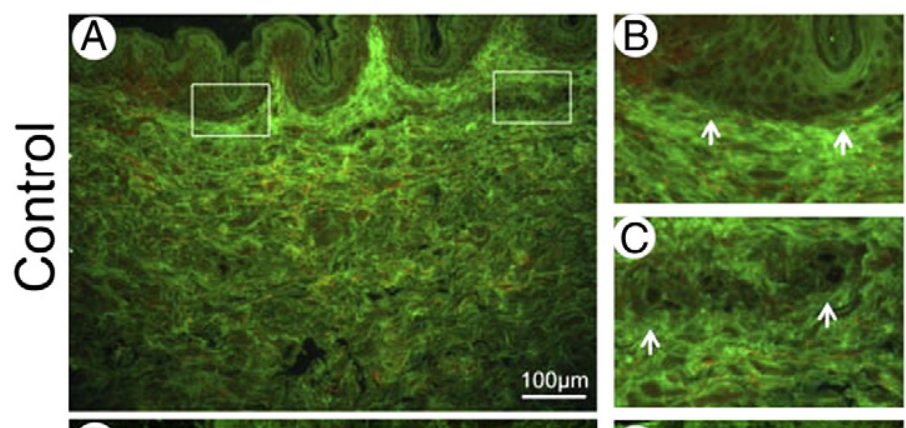

\section{(J)}
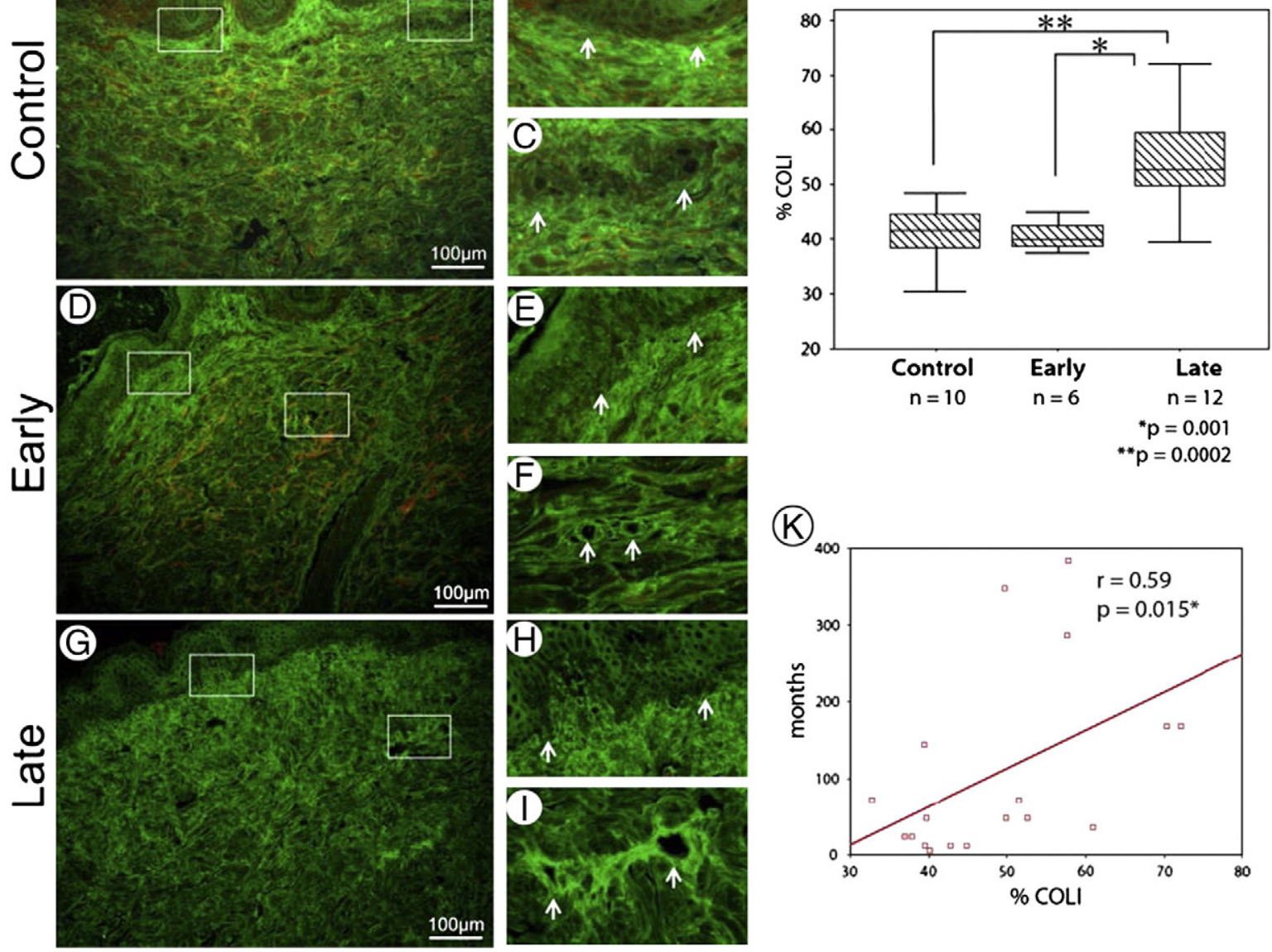

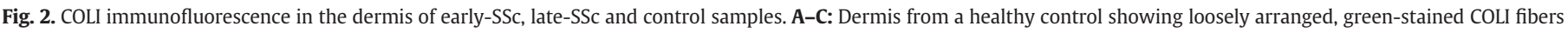

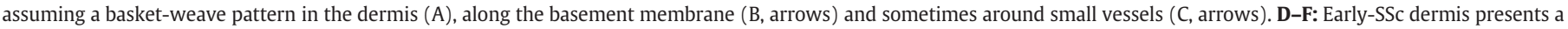

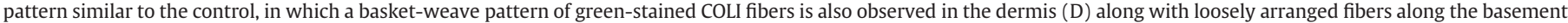

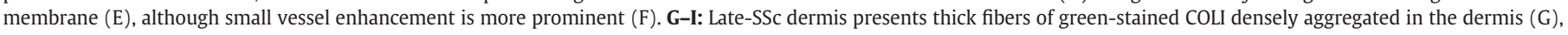

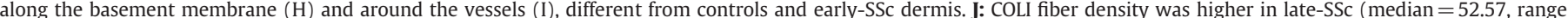

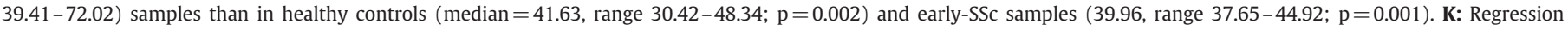
line showing a positive correlation between COLI and disease duration in months.

fibers were not observed in basement membrane (Fig. 3B). In contrast, the dermis from early-SSc patients exhibited thin COLIII fibers irregularly distributed along the basement membrane (Fig. 3D-E). These fibers involved small vessels (Fig. 3F) and diffusely permeated the papillary and reticular layers (Fig. 3D). In dermis of patients with late SSc the thin fibers of COLIII were found in a homogeneous and linear distribution along the basement membrane (Fig. 3G-H) and small vessels (Fig. 3I) and permeating the reticular dermis (Fig. 3G).

COLIII expression was markedly increased in early-SSc dermis; on average, it was $100 \%$ higher than that in normal dermis (Fig. 3J). In contrast to COLV and COLI, there was no correlation between COLIII deposition and disease duration.

No difference was found in COLI, COLIII and COLV expression between the limited and diffuse form of SSc, as well as between different pattern of internal organ involvement or autoantibody profile.

\subsection{Skin thickening and disease activity correlation with COLV}

To evaluate the clinical relevance of COLV overexpression in the dermis of SSc patients, we tested whether a significant correlation between skin thickening (measured with the MRSS) and disease activity (measured with the Valentini Disease Activity Index) was present. A positive correlation was observed with both the MRSS and Valentini
Disease Activity Index $(r=0.42, p=0.04$ and $r=0.45, p=0.03$, respectively), with regression lines shown in Figs. 4A and B.

On the other hand, COLI and COLIII were not correlated with MRSS ( $\mathrm{r}=-0.20, \mathrm{p}=0.23$ and $\mathrm{r}=-0.16, \mathrm{p}=0.18$; respectively) or disease activity $(\mathrm{r}=-0.03, \mathrm{p}=0.44$ and $\mathrm{r}=-0.05, \mathrm{p}=0.42$; respectively).

\section{3. mRNA expression of COLI, III and V chains}

To quantify relevant changes in the mRNA levels of these collagen chains, real time RT-PCR was performed in the dermal fibroblast cell culture. The mRNA expression of COLV $\alpha 1$ in dermal fibroblasts from SSc patients was 2.2-fold greater and COLV $\alpha 2$ was 5.9-fold greater than that observed in normal fibroblasts (Fig. 5). As expected, SSc patients presented the COLI $\alpha 1$ and COLIII $\alpha 1$ chain genes at rates 4.5 and 2.9 times greater, respectively, than those observed in controls (Fig. 5).

\subsection{Three-dimensional reconstruction of COLI, COLIII and COLV in dermal fibroblast culture}

Three-dimensional COLV reconstruction was performed to better evaluate collagen architecture and spatial organization. In both early and late SSc, COLV fibers were thickened, distorted and organized in dense aggregates (Fig. 6A). This pattern differed from that of the 

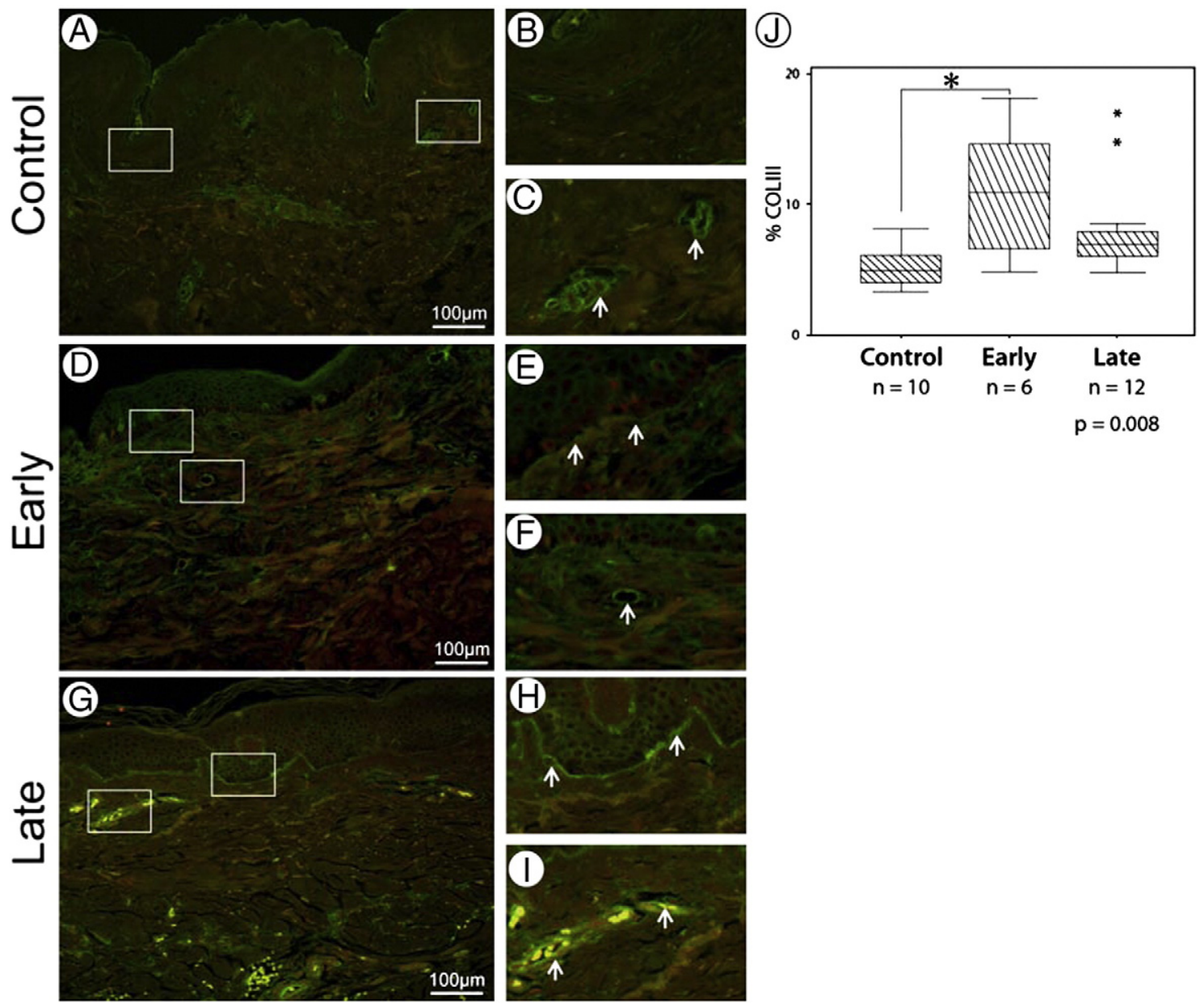

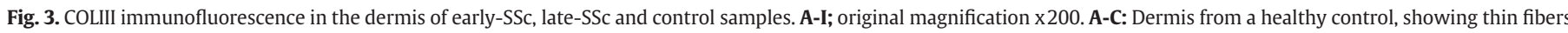

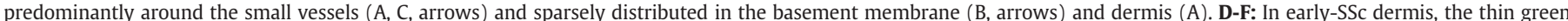

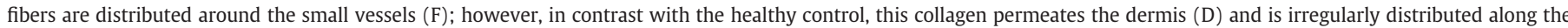

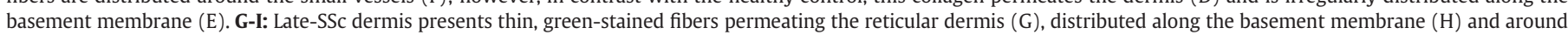

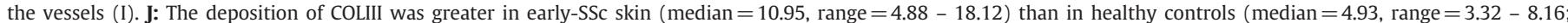
$\mathrm{p}=0.008)$.

control samples, in which fibers were thin, scarce and distributed parallel one to another (Fig. 6B), reinforcing histological findings.

Double immunofluorescence of COLV and COLI showed that they formed irregular aggregates (Fig. 6C), and both fiber types were thickened. In contrary, COLI and COLV in the fibroblast cell cultures of controls were distributed parallel one to another (Fig. 6D). COLIII fibrils of both SSc (Fig. 6E) patients and controls (Fig. 6F) were thin. However, in SSc patients, these fibrils were distributed in parallel to COLV fibrils (Fig. 6E), while in healthy controls (Fig. 6F), COLIII fibrils showed a reticular distribution, forming a loose mesh.

\section{Discussion}

The main findings of this work are that COLV is distorted and overproduced in SSc patients, mainly in the early disease stage, and is correlated to important measurements of disease activity and cutaneous severity: Valentini Disease Activity Index and skin thickening (measured with the MRSS). These findings include COLV as an important regulator of the cutaneous thickness in SSc and may add COLV as a new target for future treatments.

There are few reliable clinical and laboratory parameters to assess scleroderma disease activity [17]. In the present study, we used the Valentini Disease Activity Index, which includes measures of the degree of skin thickening, scleroderma, digital necrosis, arthritis, carbon monoxide transfer factor, erythrocyte sedimentation rate and hypocomplementemia [17]. Skin biopsy is usually performed as a diagnostic procedure because it reveals collagen accumulation in the dermis. Our results suggest that COLV immunostaining morphometry could be a valuable laboratory procedure for establishing disease activity and possibly indicating a prognosis.

In the present study, in agreement with the literature, we found increased COLIII and COLV deposition in early SSc $[28,29]$ and increased COLI expression in late stages of the disease $[28,30]$. Interestingly, as the disease progressed to later stages, the amount of distorted COLV fibers diminished, and the COLI content increased. This finding indicates that collagen remodeling in SSc is a dynamic process, and the fact that abnormal COLV expression decreases in later disease stages could explain why skin thickening sometimes improves spontaneously with time [31].

In fact, a relationship has been found between the MRSS and COLV deposition, demonstrated by the overproduction of atypical COLV in more severe skin-thickening cases, indicating that quantitative changes of COLV fibers could explain skin fibrosis. In contrast to SSc, Ehlers-Danlos syndrome, characterized by skin that is soft, velvety, fragile and hyperextensible, presents a significant reduction in COLV fibril content [32], reinforcing the relevance of COLV in the thickness of tissues. In addition to the quantitative changes, tightly packed COLV fibers may contribute to cutaneous thickening, as the distribution and organization of the collagen network affects the mechanical properties of the tissues. In fact, the organization of collagen fibers 

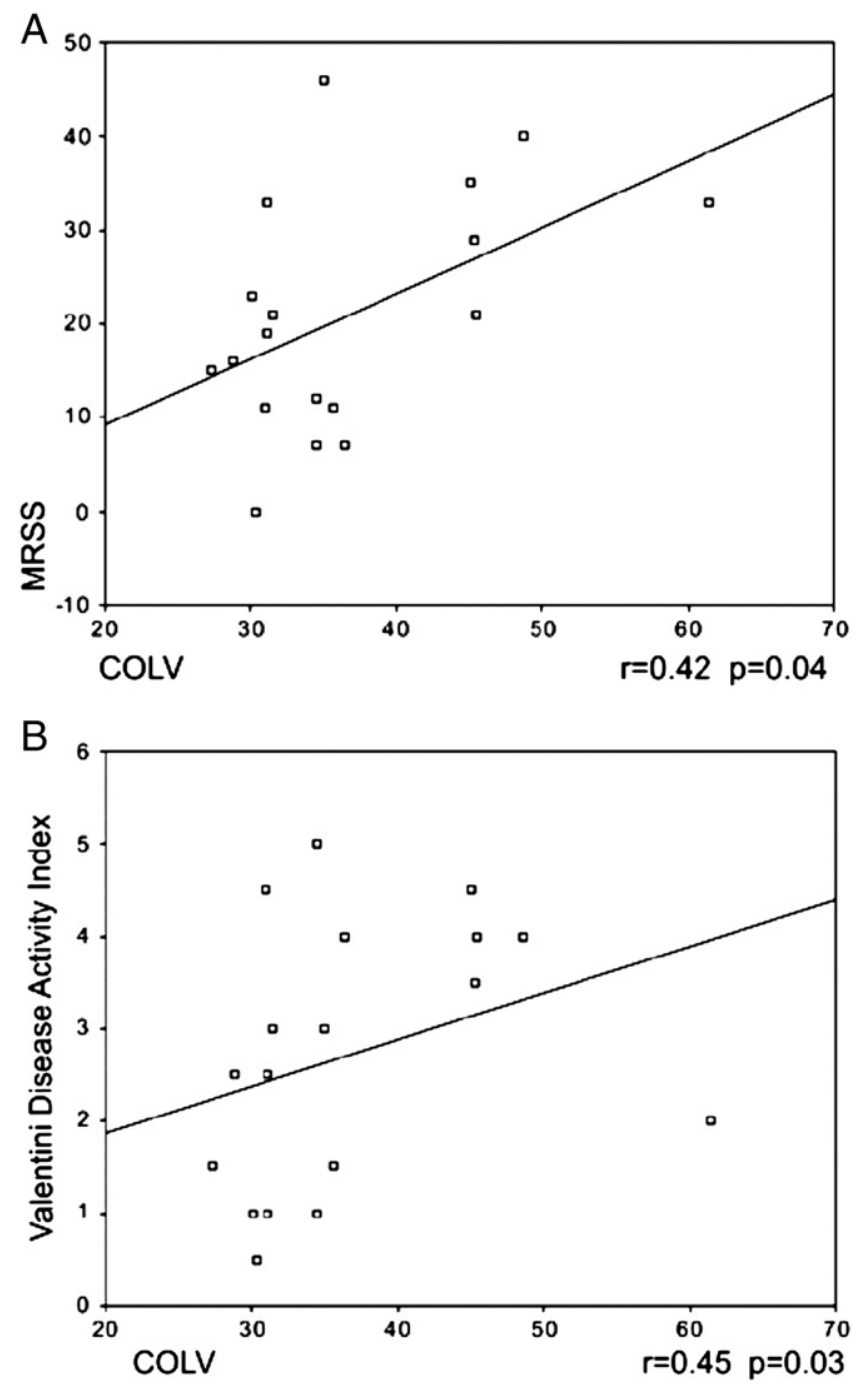

Fig. 4. Clinical correlations. (A) Regression line showing a positive correlation between COLV and skin thickening, as measured with the MRSS. (B) Regression line showing a positive correlation between COLV and disease activity, as measured with the Valentini Disease Activity Index.

into orthogonal lamellae is necessary for the transparency of cornea, while parallel distribution of collagen fibrils confers resistance and strength to tendons [3].

The increase in abnormal COLV is not a restricted phenomenon observed in the skin of patients with limited or diffuse SSc, as reported here. Our group has demonstrated that patients with interstitial lung involvement due to SSc showed an increased deposit of distorted COLV fibers at the alveolar septa and preacinar artery wall [8]. A high expression level of atypical COLV was inversely associated with vital capacity, forced vital capacity, forced expiratory volume and diffusing capacity for carbon monoxide [8]. Such results led us to conclude that atypical COLV molecules are a common feature in different organs affected by SSc.

The question of why COLV is overexpressed in SSc patients is an important one. The increased levels of COLV mRNA expression reported here suggest regulation at the transcription level, probably regulated by TGF- $\beta$. In fact, previous studies using DNA microarray analysis have proven that TGF- $\beta$ signalizing can promote increased COLV $\alpha 1$ and COLV $\alpha 2$ gene expression in skin [33] and dermal fibroblasts culture [22] of SSc patients. Another question is why COLV is distorted and thickened. The increased lysyl hydroxylase gene expression, which results in excessive formation of hydroxylysine aldehyde-derived cross-links [34], indicates that post-translational

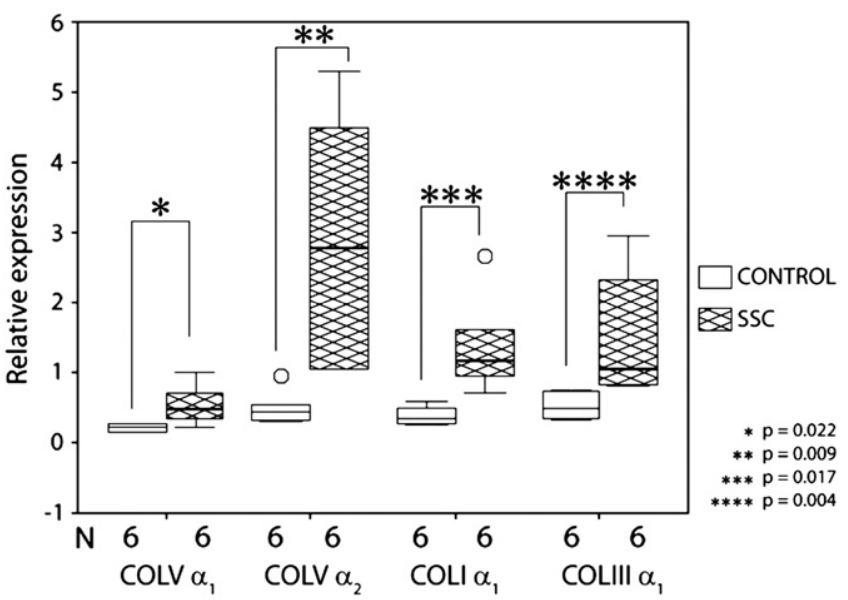

Fig. 5. Real time RT-PCR of COLV, COLI and COLIII in dermal fibroblasts culture. COLV $\alpha_{1}$ mRNA expression in SSc is 2.2-fold higher than that in the control group, whereas $\operatorname{COLV} \alpha_{2}$ expression was 5.9-fold greater than that observed in normal fibroblasts. The mRNA expression of COLI $\alpha_{1}$ was 4.5 -fold higher than that in healthy controls, and COLIII expression was 2.9-fold greater than that in healthy controls.

changes could result in morphological abnormalities in the COLV of the SSc patients. In addition, defective glycosylation of COLV fibrils may also explain the thickening, because glycosylated hydroxylysine residues prevent the lateral assembly of triple-helical and, thus, the formation of ordered fibrils [35].

The properties of COLV are poorly understood, but this fibril is very important for controlling the development of a functional skin matrix $[6,7]$. The triple-helical portion of COLV is found hidden inside the heterotypic fibril, and the preserved amino terminal globular domain projects onto the surface, regulating the diameter of these fibers [4-7]. Notably, we observed that COLI fibers were also thickened, indicating that COLV had probably lost its regulatory function.

The etiology of SSc is unknown, but some studies suggest that unknown antigens are responsible for T-cell activation, which triggers all of the steps of disease onset [36,37]. We suggest that COLV is a potential trigger antigen because it induces an experimental model of scleroderma in rabbits [10-13] and because it is related to lung transplant rejection in experimental models [38] and human patients $[39,40]$. Furthermore, the induction of COLV oral tolerance inhibited acute and chronic lung rejection in animals [41,42]. Similarly, COLVinduced nasal tolerance in the experimental model of SSc reverted skin [43] and pulmonary remodeling processes [44]. In human SSc, patients display anti-COLV antibodies, especially in the presence of vascular injury [45].

Another relevant COLV property is its capacity to promote endothelial cell apoptosis [26] via caspase activation [46]. In fact, COLV immunization of healthy rabbits induced endothelial apoptosis in lung vessels [47], and a positive correlation between COLV expression and endothelial cell apoptosis has been observed in the lungs of SSc patients [8]. Endothelium apoptosis via caspase-3 activation can release profibrotic mediators, such as CTGF, which perpetuates fibroblast activation and collagen production [48]. A COLV-induced SSC experimental model demonstrated that the collagen accumulation in dermis occurs seven days after the first immunization, which could be the result of endothelium apoptosis [49]. In the present study, the abnormal overproduction of the COLV mainly in early-SSc reinforces these two hypotheses, suggesting that this protein can be involved in disease pathogenesis.

In summary, COLV is highly and abnormally expressed in the skin of SSc patients and correlated to MRSS and Valentini Disease Activity Index. An overproduction of abnormal COLV was demonstrated equally in the skin and lungs of SSc patients $[8,9]$ and these findings were consistently replicated in a COLV induced SSc-model [10-13], supporting the idea of COLV as a possible trigger involved in the 

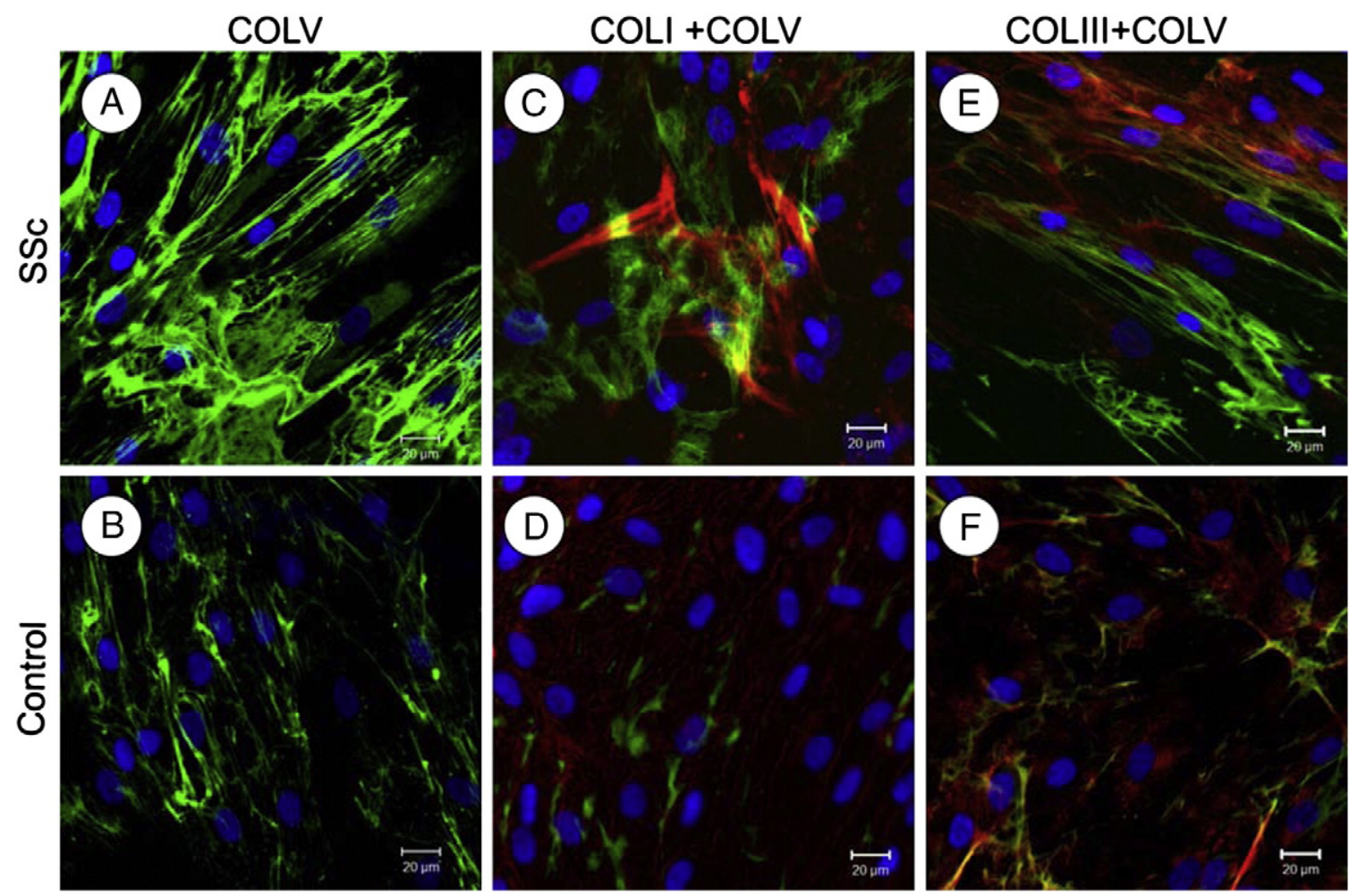

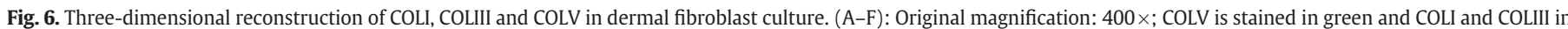

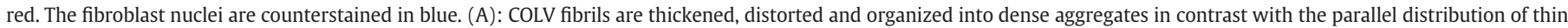

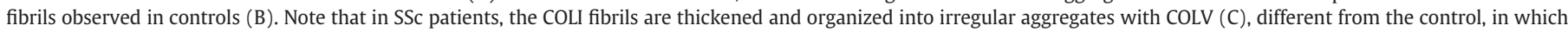

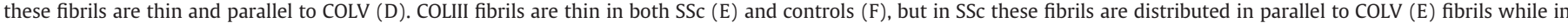
healthy controls (F) presents a reticular distribution forming a loose mesh.

pathogenesis of this devastating disease. We conclude that COLV plays an important role in the skin histoarchitectural disarrangement and thickness mainly in the early stage and may be a biomarker of disease activity and cutaneous severity.

\section{Take-home messages}

- COLV is morphologically abnormal and overexpressed in the dermis of SSc patients, especially in the early disease stage.

- Quantitative and morphological alterations of COLV fibers in SSc could explain the skin fibrosis.

- A positive correlation between dermal COLV expression, cutaneous thickening and disease activity suggests that COLV may be involved in SSc pathogenesis.

\section{Acknowledgments}

The authors thank Weluma Souza for slides preparation, Ana Garippo for Confocal Microscopy data acquisition, the Skin Bank of the Department of Plastic Surgery of Hospital de Clinicas of the University of São Paulo School of Medicine (FMUSP) for donating skin fragments, mainly Dr. Cesar Isacc and Silvana C Altran. We are finally grateful to Dr. Mario G C Rocha for performing the skin biopsies used in this study and Sandra Martin that constructively criticized the manuscript.

\section{References}

[1] Derk CT, Jimenez SA. Systemic sclerosis. Current views of its pathogenesis. Autoimmunity Rev 2003;2:181-91.

[2] Quinones F, Crouch E. Biosynthesis of interstitial and basement membrane collagens in pulmonary fibrosis. Am Rev Resp Dis 1986;134:1163-71.

[3] Gelse K, Poschl E, Aigner T. Collagens: strutcture, function and byosynthesis. Adv Drug Deliv Rev 2003;55:1531-46.
[4] Birk DE, Fitch JM, Babiarz JP, Doane KJ, Linsenmayer TF. Collagen fibrillogenesis in vitro: interaction of types I and V collagen regulates fibril diameter. J Cell Sci 1990;95:649-57.

[5] Birk DE. Type V collagen: heterotipic type I/V collagen interactions in the regulation of fibril assembly. Micron 2001;32:223-37.

[6] Chanut-Delalande H, Bonod-Bidaud C, Cogne S, Malboyres M, Ramirez F, Fichard $\mathrm{A}$, et al. Development of a functional skin matrix requires deposition of collagen V heterotrimers. Mol Cell Biol 2004;24:6049-57.

[7] Roulet M, Ruggiero F, Karsenty G, LeGuellec D. A comprehensive study of the spatial and temporal expression of the col5a1 gene in mouse embryos: a clue for understanding collagen $\mathrm{V}$ function in developing connective tissues. Cell Tissue Res 2007;327:323-32.

[8] Parra ER, Aguiar Jr AC, Teodoro WR, de Souza R, Yoshinari NH, Capelozzi VL. Collagen $\mathrm{V}$ and vascular injury promote lung architectural changes in systemic sclerosis. Clin Respir J 2009;3:135-42.

[9] Parra ER, Teodoro WR, de Morais J, Katayama ML, de Souza R, Yoshinari NH, et al. Increased mRNA expression of collagen $\mathrm{V}$ gene in pulmonary fibrosis of systemic sclerosis. Eur J Clin Invest 2010;40:110-20.

[10] Teodoro WR, Velosa APP, Witzel SS, Garippo AL, Farhat C, Parra ER, et al. Architectural remodeling in lungs of rabbits induced by type $V$ collagen immunization: a preliminary morphologic model to study diffuse connective tissue diseases. Pathol Res Pract 2004;200:681-91.

[11] Bezerra MC, Teodoro WR, de Oliveira CC, Velosa AP, Ogido LT, Gauditano T, et al Scleroderma like remodeling induced by type V collagen. Arch Dermatol Res 2006;298:51-7.

[12] Marangoni RG, Parra ER, Barbeiro HV, Velosa APP, Soriano VG, Teodoro WR, et al. Experimental model of systemic sclerosis induced by collagen $V$ reproduces extra and intrapulmonary artery disfunction (Abstract). Clin Exp Rheumatol 2010;5 (62):31 Suppl.

[13] Callado MR, Viana VS, Vendramini MB, Leon ET, Bueno C, Velosa AP, et al. Autoantibody profile in the experimental model of scleroderma induced by type $\mathrm{V}$ human collagen. Immunology 2007;122:38-46.

[14] Subcommittee for scleroderma criteria of the American Rheumatism Association Diagnostic and Therapeutic Criteria Committee: preliminary criteria for the classification of systemic sclerosis (Scleroderma). Arthritis Rheum 1980;23:581-92.

[15] White B, Bauer EA, Goldsmith LA, Hochberg MC, Katz LM, Korn JH, et al. Guidelines for clinical trials in systemic sclerosis (scleroderma). I. DiseaseModification Intervention. Arthritis Rheum 1995;38:351-60.

[16] Clements PJ, Lachenbruch P, Seibold J. Inter and Intraobsever variability of total skin thickness score (modified Rodnan TSS) in systemic sclerosis. J Rheumatol 1995;22:1281-5.

[17] Valentini G, Silman AJ, Veale D. Assessment of disease activity. Clin Exp Rheumatol 2003;21(Suppl.):S39-41. 
[18] Cotton SA, Herrick AL, Jaysson MIV, Freemont A. Endothelial expression of nitric oxide synthases and nitrotyrosin in systemic sclerosis skin. J Pathol 1999;189: 273-8.

[19] Spiess K, Teodoro WR, Zorn TMT. Distribution of collagen types I, III and V in pregnant mouse endometrium. Conective Tissue Res 2007;48:99-108.

[20] Sorrel MJ, Baber MM, Caplan AJ. Site matched papilary and reticular dermal fibroblasts difer in their release of specific growth factores, cytokines and their interaction with keratinocytes. J Cell Pathol 2004;200:134-45.

[21] Coelho JC, Giugliane R. Fibroblasts of skin fragments as a tool for the investigation of genetic diseases: technical recommendations. Genet Mol Biol 2000;23:269-71.

[22] Pannu J, Gardner H, Shearstone JR, Smith E, Trojanowska M. Increased levels of transforming growth factor beta receptor type I and up regulation of matrix gene program. Arthritis Rheum 2006;54:3011-21.

[23] Livak NJ, Schmittgen TD. Analysis of relative gene expression data using real-time quantitative PCR and the 2[-Delta-Delta C(T)] method. Methods 2001:25:402-8.

[24] Souza P, Rizzardi F, Noleto G, Atanazio M, Bianchi O, Parra ER, et al. Refractory remodeling of the microenvironment by abnormal type $\mathrm{V}$ collagen, apoptosis, and immune response in non-small cell lung cancer. Hum Pathol 2010;41: 239-48.

[25] Gao MQ, Kim GB, Kang S, Choi PY, Park H, Kang KS, et al. Stromal fibroblasts from the interface zone of human breast carcinomas induce an epithelial-mesenchymal transition-like state in breast cancer cells in vitro. J Cell Sci 2010;123: 3507-14.

[26] Behr J, Furst DE. Pulmonary function tests. Rheumatology 2008;47:v65-7.

[27] Wells AU. High-resolution computed tomography and scleroderma lung disease. Rheumatology 2008;47:v59-61.

[28] Fleischmajer R, Gay S, Meigel WN, Perlish J. Collagen in the cellular and fibrotic stages of scleroderma. Arthritis Rheum 1978;21:418-27.

[29] Liu T, Zhang J. Detection of V, III and I type collagens of dermal tissues in skin lesions of patients with systemic sclerosis and its implication, J. Huazhong. Univ Sci Technol Med Sci 2008;28:599-603.

[30] Corriveau MP, Noufaied I, Lessard J. The fibrotic phenotype of systemic sclerosis fibroblasts varies with disease duration and severity of skin involvement: reconstruction of skin fibrosis development using a tissue engineering aproach. J Pathol 2009;217:534-42.

[31] Wigley FM, Hummers LK. Clinical features of systemic sclerosis. In: Hochberg MC Silman AJ, Smolen JS, Weinblatt M, Weisman M, editors. Rheumatology. London: Elsevier Limited; 2003. p. 1463-79.

[32] Malfait F, Wenstrup RJ, de Paepe A. Clinical and genetic aspects of Ehlers-Danlos syndrome, classic type. Genet Med 2010;12:597-605.

[33] Sargent JL, Milano A, Bhattachayya S, Varga J, Connoly MK, Chang HY, et al. A TGFB-responsive gene signature is associated with a subset of diffuse scleroderma with increased disease severity. J Invest Dermatol 2010;130:694-705.

[34] Brinckmann J, Kim S, Wu J, Reinhardt DP, Batmunkh C, Metzen E, et al. Interleukin 4 and prolonged hypoxia induce a higher gene expression of lysil hidroxylase 2 and an altered cross link pattern: important pathogenetic steps in early and late stage of systemic scleroderma. Matrix Biol 2005;24:459-68.

[35] Henkel W, Dreisewerd K. Cyanogen bromide peptides of the fibrillar collagens I, III, and $\mathrm{V}$ and their mass spectrometric characterization: detection of linea peptides, peptide glycosylation, and cross-linking peptides involved in formation of homo- and heterotypic fibrils. J Proteome Res 2007;6:4269-89.

[36] Sakkas LI, Platsoucas CD. Is systemic sclerosis an antigen-driven T cell disease? Arthritis Rheum 2004;50:1721-33.

[37] Sakkas LI, Xu B, Artlett CM, Lu S, Jimenez SA, Platsoucas CD. Oligoclonal T cell expansion in the skin of patients with systemic sclerosis. J Immunol 2002;168: 3649-59.

[38] Haque MA, Mizobuchi T, Yasufuku K, Fujisawa T, Brutkiewicks RR, Zeng Y, et al Evidence for immune responses to a self-antigen in lung transplantation: role of type $\mathrm{V}$ collagen-specific $\mathrm{T}$ cells in the pathogenesis of lung allograft rejection. J Immunol 2002;169:1542-9.

[39] Bharat A, Fields RC, Steward N, Trulock EP, Patterson GA, Mohanakumar T. CD4+25+ regulatory $\mathrm{T}$ cells limit Th1-autoimmunity by inducing IL-10 producing $\mathrm{T}$ cells following human lung transplantation. Am J Transplant 2006;6:1799-808.

[40] Jaramillo A, Smith MA, Phelan D, Sundaresan S, Trulock EP, Lynch JP, et al. Development of ELISA-detected anti-HLA antibodies precedes the development of bronchiolitis obliterans syndrome and correlates with progressive decline in pulmonary function after lung transplantation. Transplantation 1999;67:1155-61.

[41] Yasufuku K, Heidler KM, O'Donnell PW, Smith GN Jr, Cummings OW, Foresman $\mathrm{BH}$, et al. Oral tolerance induction by type $\mathrm{V}$ collagen downregulates lung allograft rejection. Am J Respir Cell Mol Biol 2001;25:26-34.

[42] Yasufuku K, Heidler KM, Woods KA, Smith Jr GN, Cummings OW, Fujisawa T, et al. Prevention of bronchiolitis obliterans in rat lung allografts by type $\mathrm{V}$ collageninduced oral tolerance. Transplantation 2002;73:500-5.

[43] Velosa APP, Teodoro WR, Oliveira CC, Dos Santos Filho A, Moutinho RF, Santos AG, et al. Collagen V nasal tolerance in experimental model of systemic sclerosis. Arch Dermatol Res 2007;229:177-89.

[44] Velosa APP, Teodoro WR, dos Anjos DM, Konno R, Oliveira CC, Katayama ML, et al. Collagen V-induced nasal tolerance downregulates pulmonary collagen mRNA gene and TGF-beta expression in experimental systemic sclerosis. Respir Res 2010;11:1-10.

[45] Riente L, Marchini B, Dolcher MP, Puccetti A, Bombardieri S, Migliorini P. Anticollagen antibodies in systemic sclerosis and in primary Raynaud's phenomenon. Clin Exp Immunol 1995;102:354-9.

[46] Luparello C, Sirchia R. Type V collagen regulates the expression of apoptotic and stress response genes by breast cancer cells. J Cell Physiol 2005;202:411-21.

[47] Marangoni RG, Parra ER, Velosa APP, Teodoro WR, Capelozzi VL, Yoshinari NH. Endothelial dysfunction and abnormal COLV deposition in pulmonary vasculature of experimental systemic sclerosis model (Abstract). Arthritis Rheum 2011;62 (Suppl.):S253.

[48] Laplante P, Sirois I, Raymond MA, Kokta V, Beliveau A, Prat A, et al. Caspase-3-mediated secretion of connective tissue growth factor by apoptotic endothelial cells promotes fibrosis. Cell Death Differ 2010;17:291-303.

[49] de Oliveira CC, Velosa APP, Parra ER, Capelozzi VL, Teodoro WR, Yoshinari NH. Histomorphometric analysis of cutaneous remodeling in the early stage of the scleroderma model. Clinics (Sao Paulo) 2009;64:577-83. 